

\section{THE INTERNATIONAL MONETARY FUND}

The IMF is the world's central organization for international monetary cooperation. With 188 member countries, it is an organization in which almost all of the countries in the world work together to promote the common good. The IMF's primary purpose is to safeguard the stability of the international monetary systemthe system of exchange rates and international payments that enables countries (and their citizens) to buy goods and services from one another. This is essential for achieving sustainable economic growth and raising living standards.

All of the IMF's member countries are represented on its Executive Board, which discusses the national, regional, and global consequences of each member's economic policies. This Annual Report covers the activities of the Executive Board and IMF management and staff during the financial year May 1, 2011, through April 30, 2012.

\section{The main activities of the IMF include}

- providing advice to members on adopting policies that can help them prevent or resolve a financial crisis, achieve macroeconomic stability, accelerate economic growth, and alleviate poverty;

- making financing temporarily available to member countries to help them address balance of payments problems, that is, when they find themselves short of foreign exchange because their payments to other countries exceed their foreign exchange earnings; and

- offering technical assistance and training to countries, at their request, to help them build the expertise and institutions they need to implement sound economic policies.

The IMF is headquartered in Washington, D.C., and, reflecting its global reach and close ties with its members, also has offices around the world.

Additional information on the IMF and its member countries can be found on the Fund's website, www.imf.org.

Ancillary materials for the Annual Report—Web Boxes, Web Tables, Appendixes (including the IMF's financial statements for the financial year ended April 30, 2012), and other pertinent documents-can be accessed via the Annual Report web page at www.imf.org/external/pubs/ft/ar/2012/eng. Print copies of the financial statements are available from IMF Publication Services, P.O. Box 92780, Washington, DC 20090. A CD-ROM version of the Annual Report, including the ancillary materials posted on the web page, is also available from IMF Publication Services.

\section{ACRONYMS AND ABBREVIATIONS}

AML

AML/CFT

BIS

COFER

CSO

EAC

EFF

EUO

FATF

FCL

FM

FSB

FY

G-20

GDDS

GDP

GFSR

GRA

HIPC

HQ1

IEO

ILO

IMF

IMFC IT

MAP

MDRI

NAB

OAP

OIA

PCL

PIN

PLL

PR

PRGT

PSI

REO

RTAC

SBA

SDDS

SDMX

TA

TSR

TTF

WEO anti-money laundering

anti-money laundering and combating the

financing of terrorism

Bank for International Settlements

Currency Composition of Foreign Exchange Reserves

civil society organization

External Audit Committee

Extended Fund Facility

Offices in Europe

Financial Action Task Force

Flexible Credit Line

Fiscal Monitor

Financial Stability Board

financial year

Group of Twenty

General Data Dissemination System

gross domestic product

Global Financial Stability Report

General Resources Account

Heavily Indebted Poor Countries

main headquarters

Independent Evaluation Office

International Labour Organization

International Monetary Fund

International Monetary and Financial Committee

information technology

Mutual Assessment Process

Multilateral Debt Relief Initiative

New Arrangements to Borrow

Office for Asia and the Pacific

Office of Internal Audit and Inspection

Precautionary Credit Line

Public Information Notice

Precautionary and Liquidity Line

press release

Poverty Reduction and Growth Trust

Policy Support Instrument

Regional Economic Outlook

regional technical assistance center

Stand-By Arrangement

Special Data Dissemination Standard

Statistical Data and Metadata Exchange

technical assistance

Triennial Surveillance Review

topical trust fund

World Economic Outlook

\section{CInternational Monetary Fund. Not for Redistribution}


This page intentionally left blank 


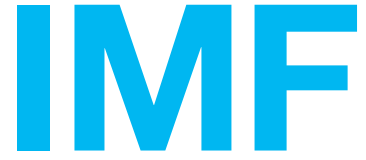

\section{INTERNATIONAL \\ MONETARY FUND}

ANNUAL REPORT 2012

WORKING TOGETHER TO SUPPORT

GLOBAL RECOVERY 


\section{CONTENTS}

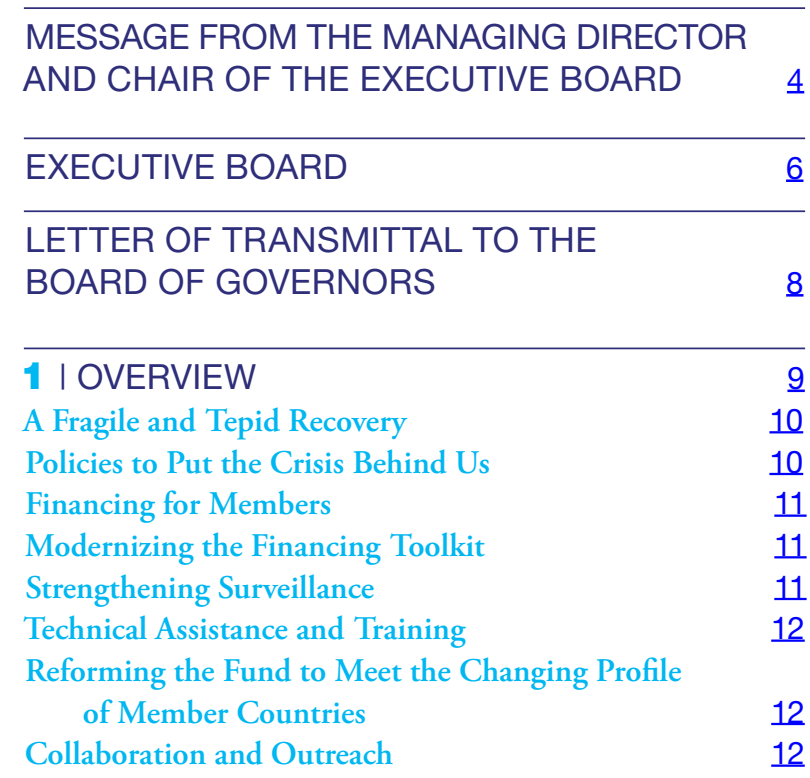

\section{I GLOBAL ECONOMIC AND FINANCIAL DEVELOPMENTS}

Two Steps Forward, One Step Back

Getting Two Steps Ahead

\section{I SUPPORTING GLOBAL RECOVERY}

Financial Support to Countries during the Crisis

Global safety net

Stronger Surveillance to Support a Return to

Sustainable Global Growth

Strengthening surveillance

Capital flows

Risk assessment and management

Role of the SDR

\section{I BUILDING CAPACITY FOR SUSTAINED GROWTH}

Support for Low-Income Countries

Heavily Indebted Poor Countries and Multilateral

Debt Relief Initiatives

Review of the Joint IMF-World Bank Debt

Sustainability Framework for Low-Income

Countries
Building Capacity in Member Countries

Technical assistance

Training

Data and Data Standards Initiatives

The IMF's standards for data dissemination

Eighth Review of the Fund's Data Standards

$$
\text { Initiatives }
$$

$\underline{45}$

Other data-related activities

Collaboration with Group of Twenty and other organizations $\quad 47$

IMF collaboration with the G-20 $\underline{47}$

Participation in regional financing arrangements $\quad \underline{48}$

Collaboration with other organizations

48

\section{I GOVERNANCE, FINANCES, AND} ACCOUNTABILITY

Quota and Governance Reform

$\underline{50}$

Progress on the 2010 quota and governance reform $\underline{50}$

Review of the quota formula

$\underline{51}$

Resources, Income, and Budget $\underline{51}$

Borrowing agreements $\underline{51}$

Income, charges, remuneration, and burden sharing $\underline{52}$

Administrative and capital budgets $\underline{54}$

Arrears to the IMF $\underline{56}$

Audit mechanisms $\quad \underline{56}$

Risk management $\quad \underline{57}$

Membership $\quad \underline{58}$

Human Resources Policies and Organization $\underline{58}$

Human resources in FY2012 $\underline{58}$

Management changes $\quad \underline{60}$

Accountability $\underline{61}$

Transparency $\underline{61}$

Independent Evaluation Office $\underline{61}$

Ethics framework for staff, management, and the Executive Board $\underline{62}$

Engagement with external stakeholders $\quad \underline{63}$

EXECUTIVE DIRECTORS AND ALTERNATES $\underline{66}$

SENIOR OFFICERS $\quad \underline{67}$

IMF ORGANIZATION CHART $\quad \underline{68}$




\section{BOXES}

3.1. Fund engagement in the euro area

3.2. Support to Arab transition countries

3.3. Key elements of the new instruments

3.4. Using anti-money laundering measures in Fundsupported programs: Afghanistan and Greece

4.1. Japan's contribution to IMF technical assistance

4.2. Evaluating the effectiveness of IMF Institute training

4.3. Mobile applications for IMF statistical data

4.4. Public Sector Debt Statistics: Guide for Compilers and Users

5.1. Building renovations

5.2. Farewell to John Lipsky

5.3. The Independent Evaluation Office's tenth anniversary conference

5.4. IMF launches Arabic blog

5.5. Conference on public health care reform in Asia

\section{FIGURES}

3.1. Arrangements approved during financial years ended April 30, 2003-12

3.2. Nonconcessional financing outstanding, FY2003-12

3.3. Concessional financing outstanding, FY2003-12

4.1. Technical assistance delivery in FY2007-12 by income group

4.2. Technical assistance delivery in FY2007-12 by country status

4.3. Technical assistance delivery during FY2012 by subject and region

4.4. Technical assistance delivery in FY2007-12 by subject and topic

4.5. Technical assistance delivery in FY2008-12 by financing source

\section{TABLES}

3.1. IMF financing facilities

3.2. Arrangements under main facilities approved in FY2012

3.3. Arrangements approved and augmented under the Poverty Reduction and Growth Trust in FY2012

4.1. IMF Institute training program, FY2008-12

5.1. Budget by major expenditure category, FY2011-15

5.2. Administrative expenses reported in the financial statements

5.3. Arrears to the IMF of countries with obligations overdue by six months or more and by type
The IMF's financial year is May 1 through April 30. The unit of account of the IMF is the SDR; conversions of IMF financial data to U.S. dollars are approximate and provided for convenience. On April 30, 2012, the SDR/U.S. dollar exchange rate was US\$1 = SDR 0.644934, and the U.S. dollar/SDR exchange rate was SDR $1=$ US\$1.55055. The year-earlier rates (April 30, 2011) were US\$1 = SDR 0.616919 and SDR 1 = US\$1.62096.

"Billion" means a thousand million; "trillion" means a thousand billion; minor discrepancies between constituent figures and totals are due to rounding.

As used in this Annual Report, the term "country" does not in all cases refer to a territorial entity that is a state as understood by international law and practice. As used here, the term also covers some territorial entities that are not states but for which statistical data are maintained on a separate and independent basis. 


\section{MESSAGE FROM THE MANAGING DIRECTOR AND CHAIR OF THE EXECUTIVE BOARD}

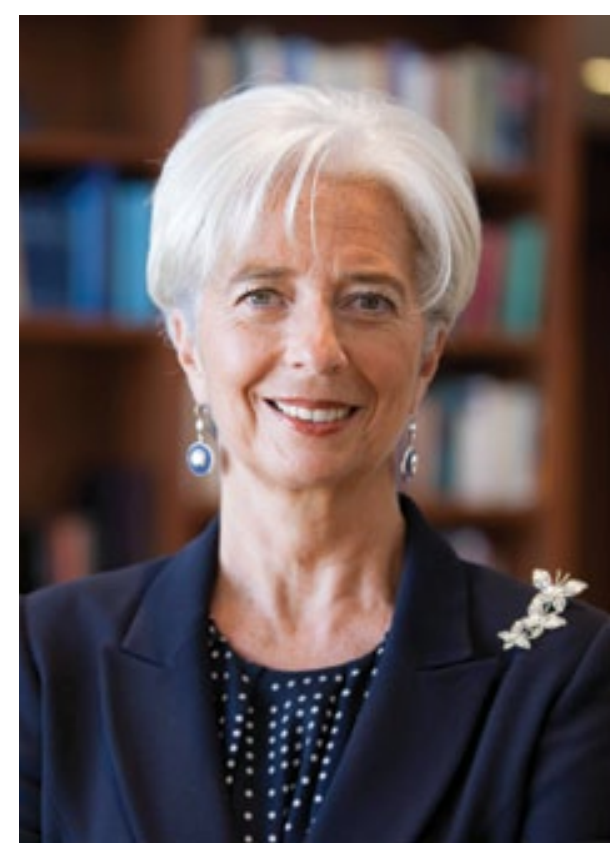

Christine Lagarde, Managing Director and Chair of the Executive Board
The past year was a deeply challenging one for many IMF members and for the Fund itself. The global financial crisis continued to flare up across the world, especially in the euro area. We saw many false hopes and too many cases of two steps forward and one step back. The result is a continued lack of confidence, continued financial market stress, and a continued weak recovery. Meanwhile, unemployment remains unacceptably high in too many regions and the social fabric is becoming increasingly stretched.

Clearly, it is more important than ever to restore global economic and financial stability and put the global economy on a course of sustained growth.

Especially in these circumstances, the IMF must continue to apply all of its analytical excellence and forward-thinking creativity to help its members overcome current problems and build a bridge to that better world.

In this respect, I am proud of the strong, independent role played by the IMF over the past financial year. We tried to be as objective and evenhanded as possible in assessing economic plans and giving advice to countries. Consider the following examples.

We called for an aggressive strategy to recapitalize European banks, to build a larger firewall to reduce contagion and restore confidence, and to use these funds to take direct stakes in banks. The Fund also called for a comprehensive plan for greater European financial and fiscal integration. We tried to bring balance to the fiscal debate, noting that an overly zealous approach to cutting budget deficits could make global economic conditions worse. And we continued to work toward better financial sector regulation and supervision, to ensure we do not return to the financial system that produced the crisis.

The Fund continued to innovate over the period and has worked hard to improve the way we do business. Following the findings of the Triennial Surveillance Review, we took steps to improve the Fund's surveillance methods and outputs, and to focus more on the risks and interconnections that pervade the modern global economy. We set out to develop a work plan for financial sector surveillance, and in the area of external stability, the Executive Board continued work to broaden systematic multilateral analysis beyond exchange rates to include external balances. The Executive Board also worked to update the existing legal framework to enable more effective conduct of surveillance. 
In our surveillance, we paid greater attention to employment, inclusive growth, and social issues, and we looked carefully at the issues facing the low-income countries, including from commodity price fluctuations. The Fund also focused its work on several broader core macro areas, including managing capital flows and modernizing the fiscal framework and debt sustainability analysis.

On the lending front, we responded flexibly to our members' financing needs, all across the world. We intensified dialogue with the Arab transition countries, laying the groundwork for possible financing support, and we maintained our support for our low-income members. Recognizing that prevention is better than cure, the Executive Board agreed to reforms to the Fund's lending toolkit that are designed to provide better liquidity and emergency assistance to our global membership. The new more flexible Precautionary and Liquidity Line, which replaced the Precautionary Credit Line, can be used in broader circumstances, including as insurance against future shocks and as a short-term liquidity window, to address the needs of members with sound economic fundamentals and policy frameworks. At the same time, our new Rapid Financing Instrument allows us to support a full range of urgent balance of payments needs, including those arising from exogenous shocks.

Over the past financial year, we also stepped up our technical assistance program. Aided by generous donor contributions, the Fund delivered significantly more technical assistance than in previous years. In addition, after a strategic review, we merged two operational units to create a new department to oversee and manage training and technical assistance delivery-the Institute for Capacity Development.

All in all, I believe the IMF had a productive year. Our members expressed their confidence in us by boosting our resources by US $\$ 456$ billion (US $\$ 430$ billion at the end of the 2012 financial year). The Executive Board also endorsed the use of a portion of the windfall profits from IMF gold sales to help raise additional funds to subsidize the Poverty Reduction and Growth Trust's concessional financing. It remains imperative to ensure adequate resources for concessional lending, so this is a welcome contribution toward subsidizing the interest rate on concessional financing arrangements with low-income members.

Looking ahead, it is important to move forward with the governance reforms agreed in 2010. The IMF must be representative of its entire membership and be seen as truly legitimate. And on this basis, the IMF will continue working with its members to find collective solutions to collective problems and chart the course to a more prosperous future.

I am deeply honored to be the Managing Director of the IMF. I am impressed by our staff, and proud of our work. I have the greatest respect for the professionalism and integrity of the IMF's Executive Board, and its tireless efforts to carry out the mandate of the IMF, day in and day out.

The Annual Report of the IMF's Executive Board to the Fund's Board of Governors is an essential instrument in the IMF's accountability. The Executive Board is responsible for conducting the Fund's business and consists of 24 Executive Directors appointed by the IMF's 188 member countries, while the Board of Governors, on which every member country is represented by a senior official, is the highest authority governing the IMF. The publication of the Annual Report represents the accountability of the Executive Board to the Fund's Board of Governors.

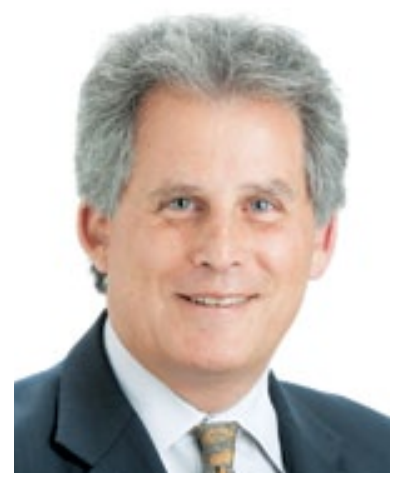

David Lipton, First Deputy Managing Director

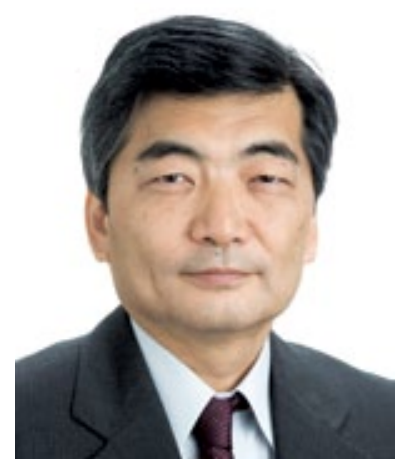

Naoyuki Shinohara, Deputy Managing Director

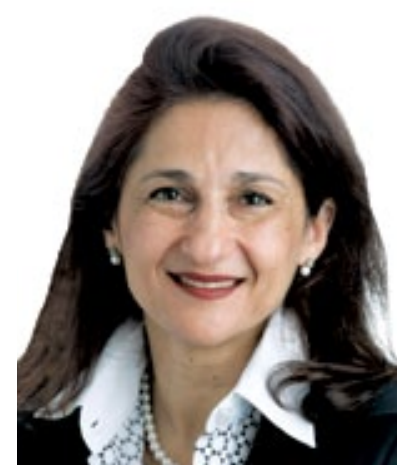

Nemat Shafik, Deputy Managing Director

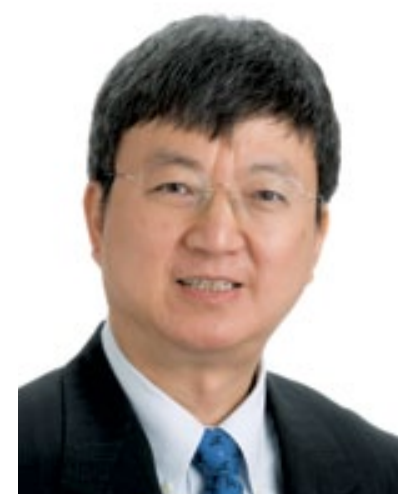

Min Zhu, Deputy Managing Director 


\section{EXECUTIVE BOARD}

Alternate Executive Directors are indicated in italics.

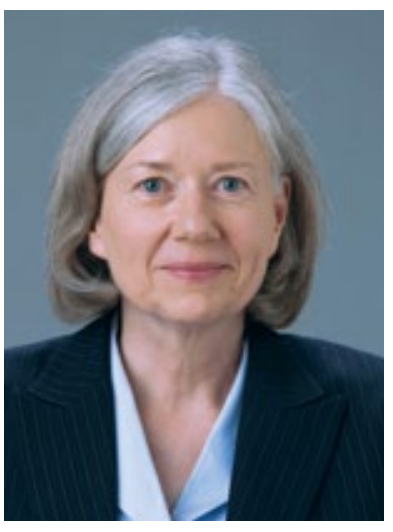

Meg Lundsager Vacant

United States

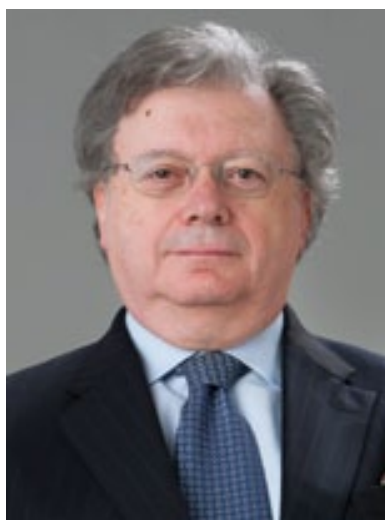

Arrigo Sadun

Thanos Catsambas

Albania, Greece, Italy, Malta, Portugal, San Marino, Timor-Leste

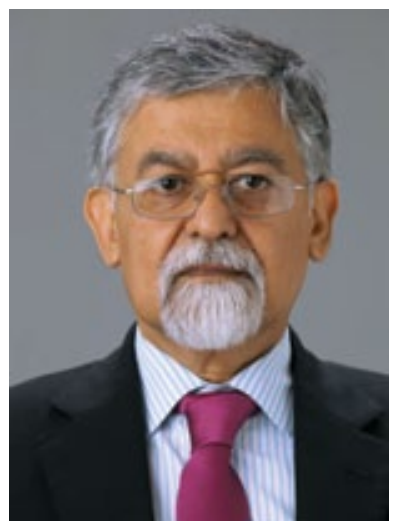

Arvind Virmani

P. Nandalal Weerasinghe

Bangladesh, Bhutan, India, Sri Lanka

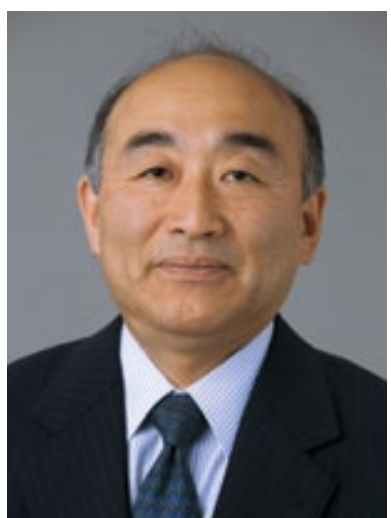

Mitsuhiro Furusawa Tomoyuki Shimoda Japan

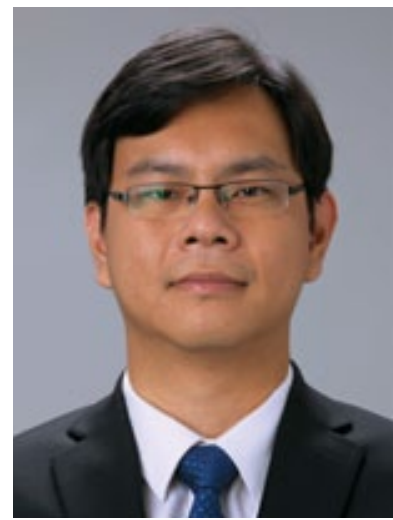

Der Jiun Chia

Aida Budiman

Brunei Darussalam, Cambodia, Fiji, Indonesia, Lao

P.D.R., Malaysia, Myanmar, Nepal, Philippines,

Singapore, Thailand, Tonga, Vietnam

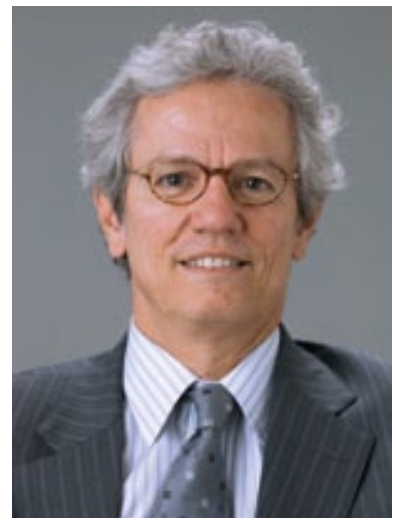

Paulo Nogueira Batista, Jr:

María Angélica Arbeláez

Brazil, Colombia, Dominican Republic, Ecuador, Guyana, Haiti, Panama, Suriname, Trinidad and Tobago

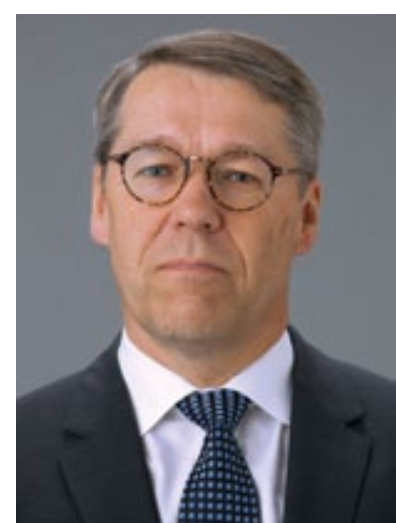

Hubert Temmeyer Steffen Meyer

Germany

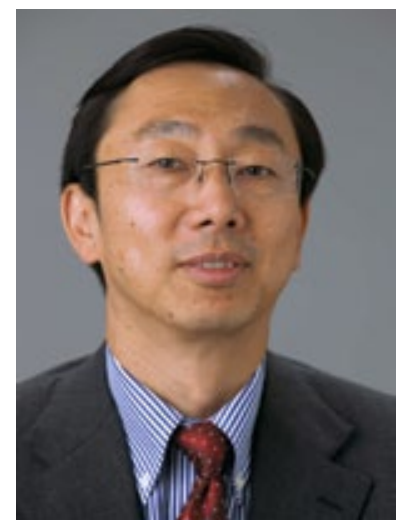

Tao Zhang

Ping Sun

China

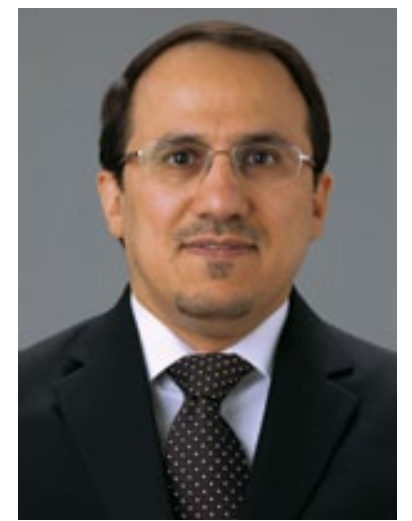

Ahmed Alkholifey

Fahad I. Alshathri

Saudi Arabia

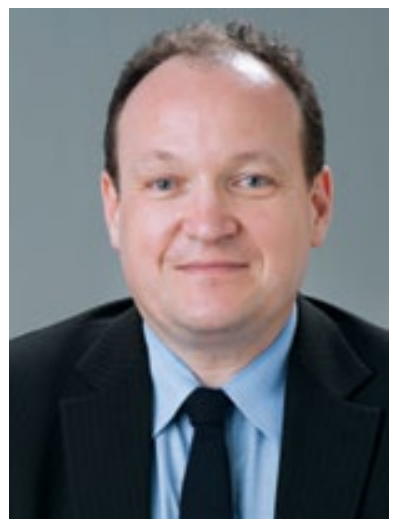

Ambroise Fayolle

Alice Terracol

France

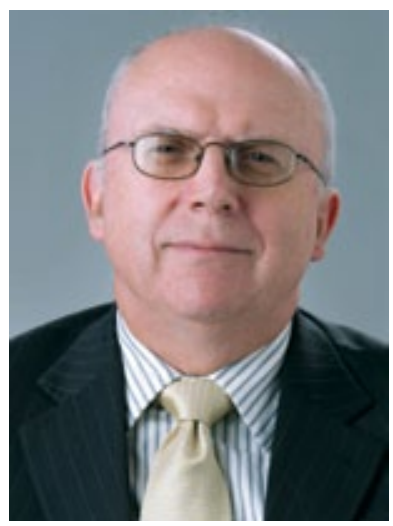

Christopher Legg

Hoseung Lee

Australia, Kiribati, Korea, Marshall Islands, Micronesia, Mongolia, New Zealand, Palau, Papua New Guinea, Samoa, Seychelles, Solomon Islands, Tuvalu, Uzbekistan, Vanuatu

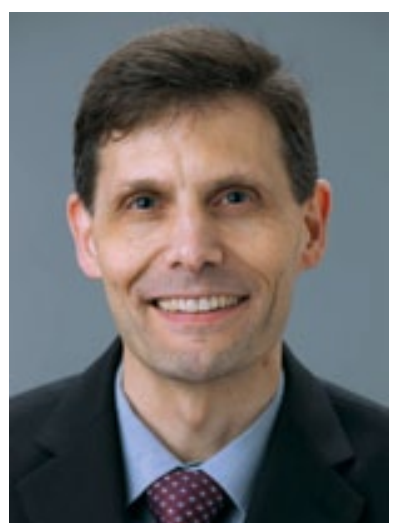

René Weber

Vacant

Azerbaijan, Kazakhstan, Kyrgyz Republic, Poland, Serbia, Switzerland, Tajikistan, Turkmenistan 


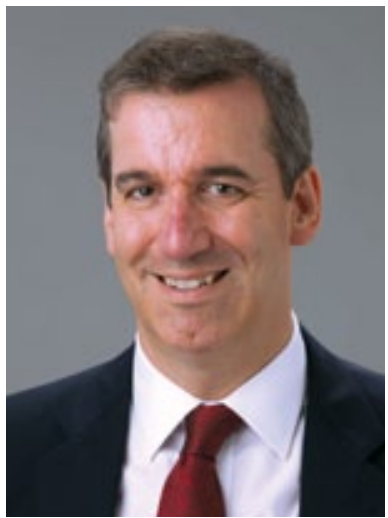

Alexander Gibbs Robert Elder United Kingdom

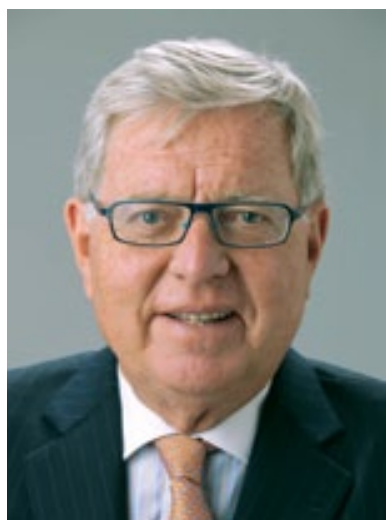

Thomas Hockin Mary O'Dea

Antigua and Barbuda, The Bahamas, Barbados, Belize, Canada, Dominica, Grenada, Ireland, Jamaica, St. Kitts and Nevis, St. Lucia, St. Vincent and the Grenadines

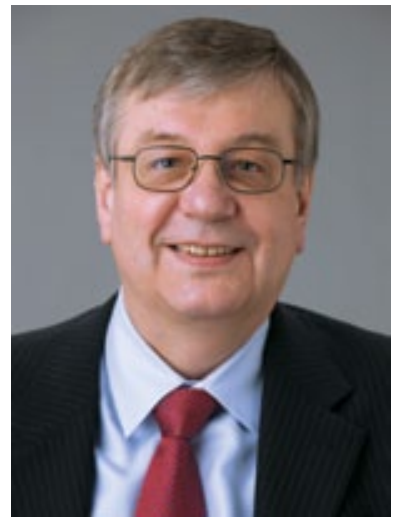

Aleksei V. Mozhin

Andrei Lushin

Russian Federatio

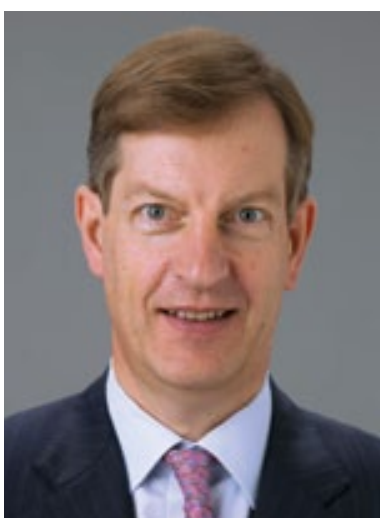

Willy Kieken

Johann Prader

Austria, Belarus, Belgium, Czech Republic, Hungary Kosovo, Luxembourg, Slovak Republic, Slovenia, Turkey

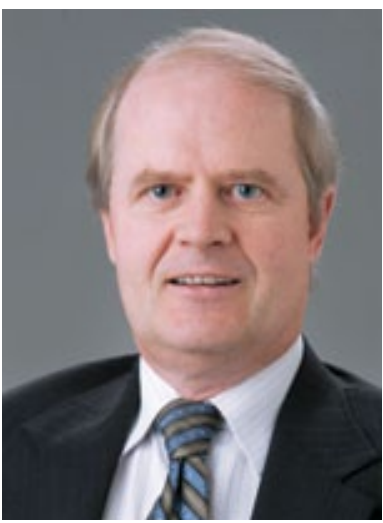

Benny Andersen

Audun Gronn

Denmark, Estonia, Finland, Iceland, Latvia, Lithuania, Norway, Sweden

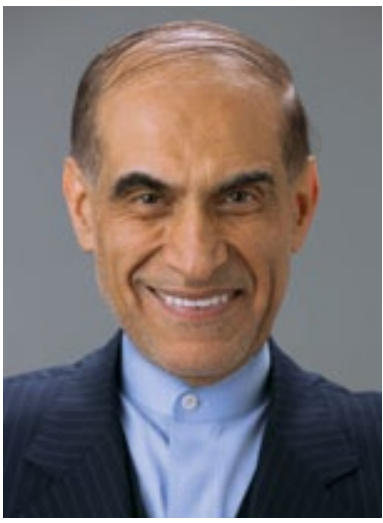

Jafar Mojarrad

Mohammed Dairi

Afghanistan, Algeria, Ghana, Islamic Republic of Iran, Morocco, Pakistan, Tunisia

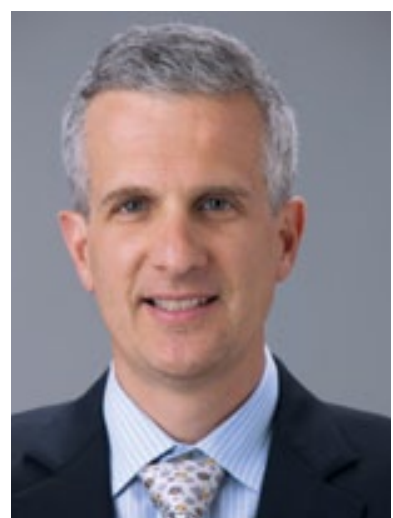

Carlos Pérez-Verdía

José Rojas Ramire

Costa Rica, El Salvador, Guatemala, Honduras, Mexico, Nicaragua, Spain, Venezuela

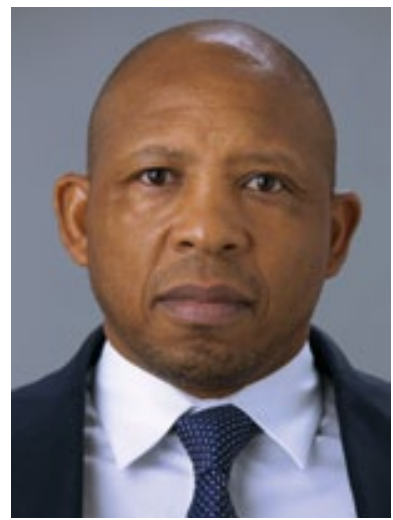

Moeketsi Majoro

Momodou Sah

Angola, Botswana, Burundi, Eritrea, Ethiopia, The Gambia, Kenya, Lesotho, Liberia, Malawi, Mozambique, Namibia, Nigeria, Sierra Leone, South Africa, Sudan, Swaziland, Tanzania, Uganda, Zambia, Zimbabwe

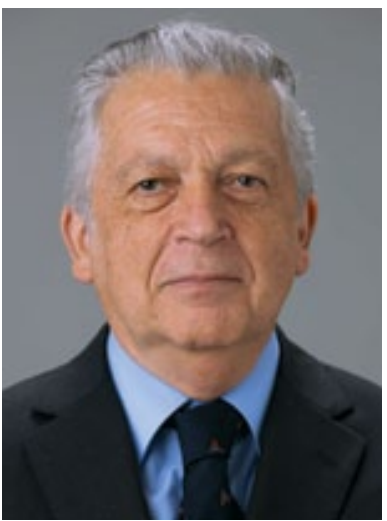

Alfredo Mac Laughlin

Pablo Garcia-Silva

Argentina, Bolivia, Chile, Paraguay, Peru, Uruguay

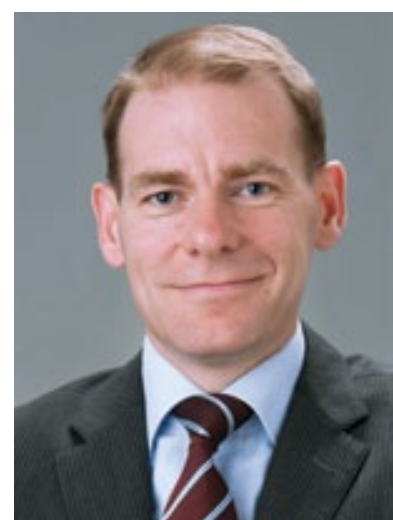

Menno Snel

Yuriy G. Yakushe

Armenia, Bosnia and Herzegovina, Bulgaria, Croatia, Cyprus, Georgia, Israel, former Yugoslav Republic of Macedonia, Moldova, Montenegro, Netherlands, Romania, Ukraine

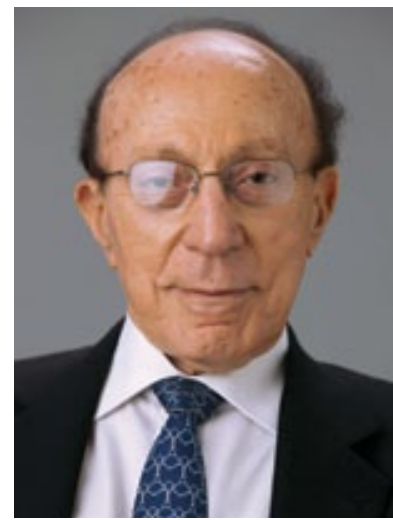

A. Shakour Shaalan

Sami Geadah

Bahrain, Egypt, Iraq, Jordan, Kuwait, Lebanon, Libya, Maldives, Oman, Qatar, Syria, United Arab Emirates, Yemen

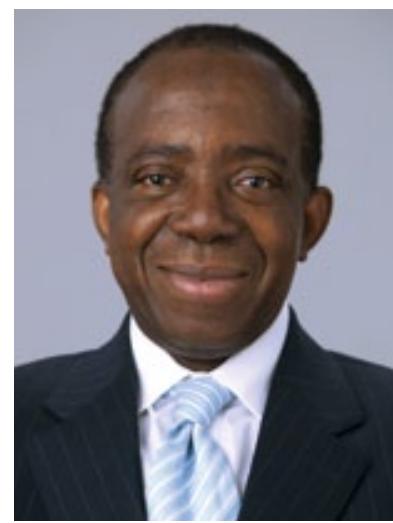

Kossi Assimaidou

Nguéto Tiraina Yambaye

Benin, Burkina Faso, Cameroon, Cape Verde, Central African Republic, Chad, Comoros, Democratic Republic of the Congo, Republic of Congo, Côte d'Ivoire, Dijbouti, Equatorial Guinea, Gabon, Guin Guinea-Bissau, Mall, Maurtania, Mauru Rwanda, São Tomé and Príncipe, Senegal, Togo 


\section{LETTER OF TRANSMITTAL TO THE BOARD OF GOVERNORS}

July 26, 2012

Dear Mr. Chairman:

I have the honor to present to the Board of Governors the Annual Report of the Executive Board for the financial year ended April 30, 2012, in accordance with Article XII, Section 7(a) of the Articles of Agreement of the International Monetary Fund and Section 10 of the IMF's By-Laws. In accordance with Section 20 of the By-Laws, the administrative and capital budgets of the IMF approved by the Executive Board for the financial year ending April 30, 2013, are presented in Chapter 5. The audited financial statements for the year ended April 30, 2012, of the General Department, the SDR Department, and the accounts administered by the IMF, together with reports of the external audit firm thereon, are presented in Appendix VI, which appears on the CD-ROM version of the Report, as well as at www.imf.org/external/pubs/ft/ar/2012/eng/index .htm. The external audit and financial reporting processes were overseen by the External Audit Committee, comprising Ms. Amelia Cabal (Chair), Mr. Arfan Ayass, and Mr. Jian-Xi Wang, as required under Section 20(c) of the Fund's By-Laws.

\section{Christine Lagarde}<smiles>[Mg][Mg][Mg]</smiles>

Managing Director and Chair of the Executive Board 


\section{OVERVIEW}

ギリス

\section{T S E 100}

N554.6 $+61.54$

インド (11/1 ムンパイ指数

\section{5}

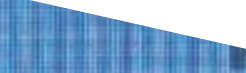
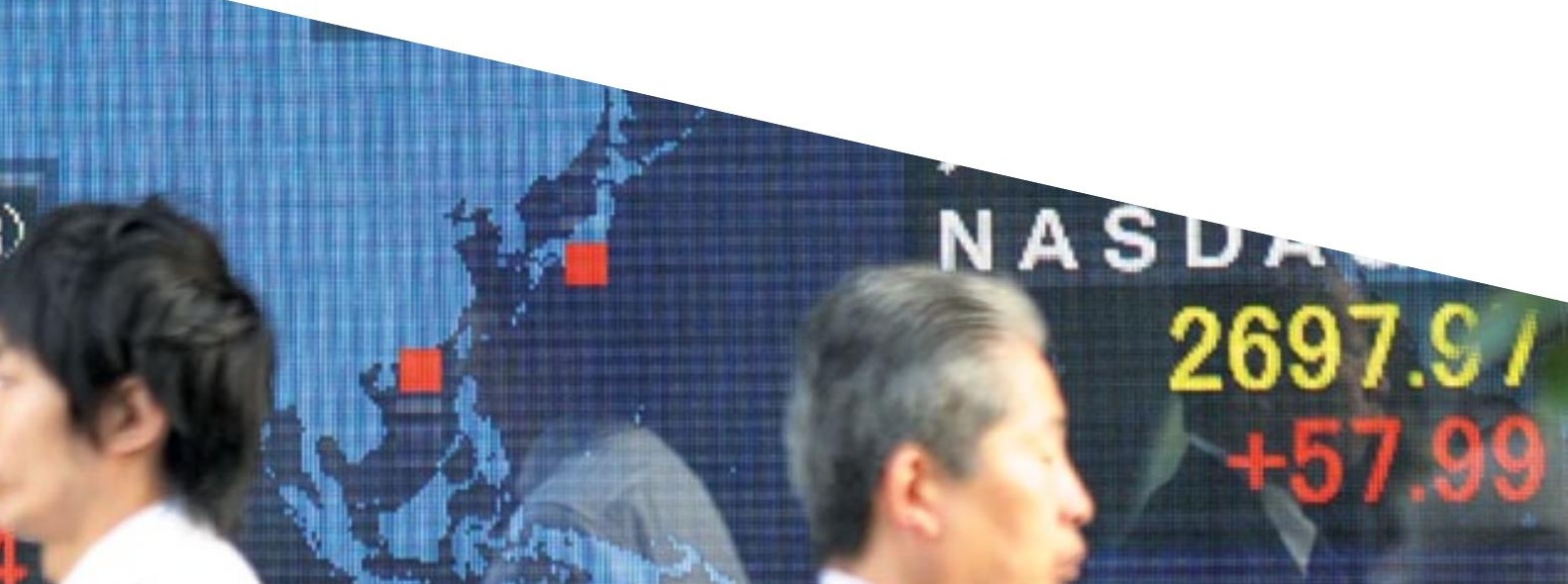

$\int_{0 \rightarrow 2}$

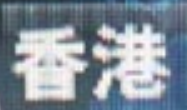

(11)

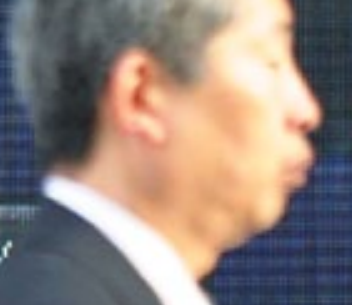

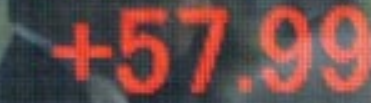

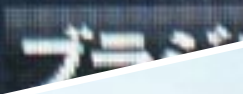

atoper

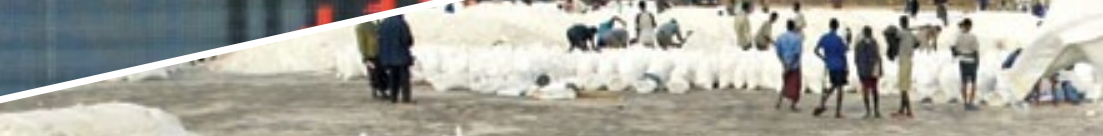




\section{OVERVIEW}

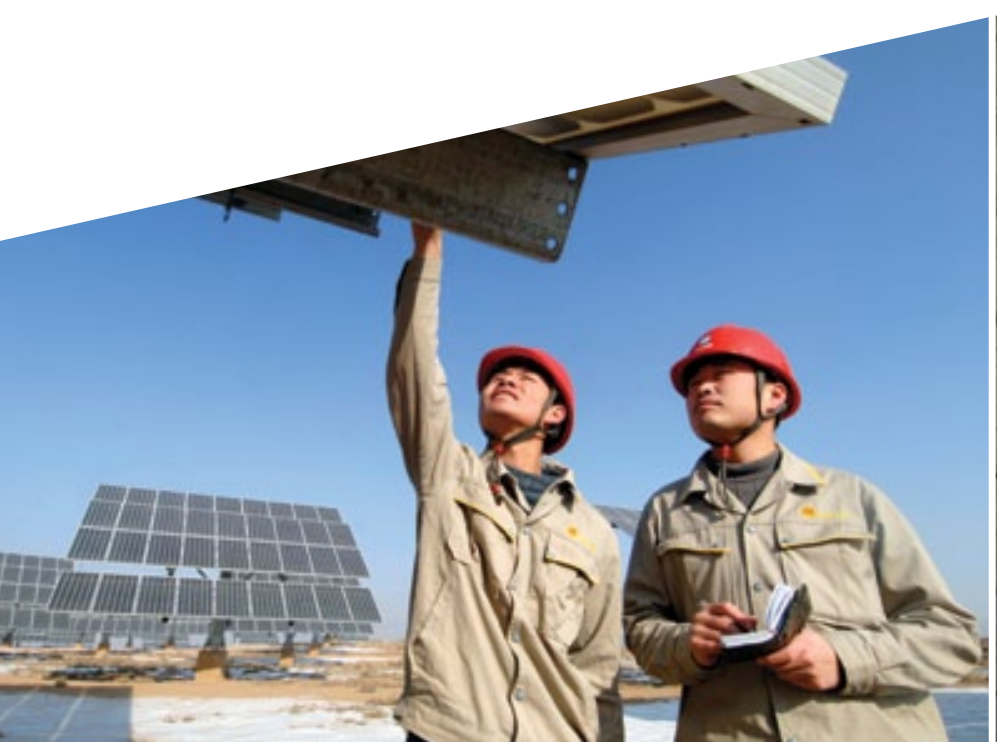

With every twist and turn in the global financial crisis that started in 2007, the International Monetary Fund (IMF) has been at the heart of efforts to restore financial stability and return the world economy to sustainable growth. This year was no exception. The Fund was focused intensely on providing the financing, policy advice, and technical assistance that members need to manage economic and financial risks and achieve lasting growth. New nonconcessional financing arrangements were initiated for seven countries. At the same time, the institution was pursuing many strands of work to strengthen its approach to surveillance and policy design, to improve the instruments in its lending toolkit, and to improve the governance structure of the organization.

By the end of the financial year, ${ }^{1}$ a significant number of countries had made firm commitments to enhance IMF resources by more than US $\$ 430$ billion, for crisis prevention and resolution and to meet the potential financing needs of all IMF members. ${ }^{2}$ This showed the commitment of the international community to putting the global economic recovery on a sounder footing, and to retaining the IMF at the heart of these efforts.

\section{A FRAGILE AND TEPID RECOVERY}

The global economy experienced a period of tentative stability in the first quarter of 2012 after a major setback in late 2011, but the recovery remained fragile as FY2012 drew to a close. Activity in the United States strengthened, and most emerging market economies and low-income countries were continuing to experience solid growth. However, recurring difficulties in the euro area led to

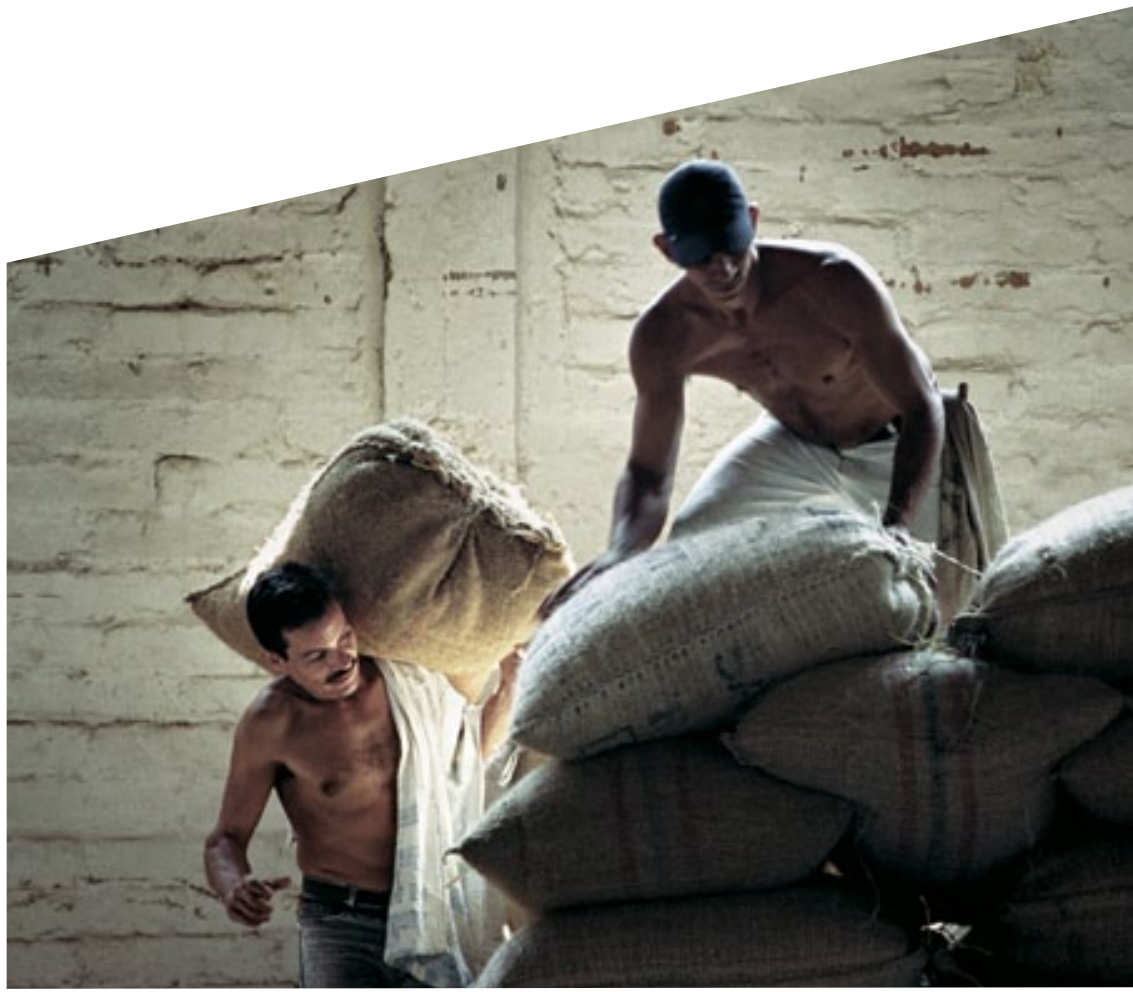

significant market stress and volatility at times and continued to pose a key source of vulnerability to the world economy. Growth in most advanced economies was expected to remain weak, held back by concerns about public deficits and debt, the ongoing process of financial deleveraging, and high unemployment. In the emerging market and developing economies, it was expected that growth would continue to be solid, though managing downside risks would continue to be challenging and some countries were facing overheating pressures related to strong credit growth.

\section{POLICIES TO PUT THE CRISIS BEHIND US}

With risks firmly to the downside, policymakers faced a challenging balancing act as FY2012 drew to a close. In advanced economies, governments had to address fiscal risks and start to put public debt on a firm downward trajectory without killing growth in the near term. Measured near-term fiscal adjustment was needed, accompanied by strong medium-term consolidation plans that included reforms to entitlement programs. These economies needed to implement structural reforms to labor and product markets to lower unemployment and bring about stronger growth. Subdued inflationary pressures and risks to growth called for continued accommodative monetary policy. For emerging market and developing economies, policymakers needed to find the right balance of macroeconomic policies that would counter global downside risks while, in some cases, keeping overheating pressures in check. All countries needed to work to ensure that the most vulnerable groups in society were protected from the fallout of the financial crisis. 
Continued policy cooperation across countries was necessary to build confidence and stability. To make further progress in addressing global imbalances and the deficit in global demand, countries with high saving rates needed to seek to address obstacles that were impeding consumption and investment, supported by more market-determined exchange rates. In addition, a key priority remained the global financial sector, in particular the need for consistent implementation of new financial sector regulations worldwide and for addressing other financial sector weaknesses such as problems related to institutions considered "too complex to fail," the shadow banking system, and cross-border supervision and bank resolution.

\section{FINANCING FOR MEMBERS}

The IMF continued in FY2012 to respond flexibly to members' financing needs in an environment of uncertainty and financial market volatility. Demand for Fund resources remained strong and commitments increased further, although at a slower pace than in the previous year. The IMF's Executive Board approved seven nonconcessional financing arrangements during the year. In addition, a new successor arrangement under the Flexible Credit Line (FCL) was approved for Colombia, while existing FCL arrangements remained in place for Mexico and Poland.

Among the Fund's low-income members, 20 countries had arrangements approved or augmented with support from the Poverty Reduction and Growth Trust (PRGT) in FY2012. By the end of the financial year, the IMF had concessional financing outstanding with 64 members. The IMF also intensified its policy dialogue, including possible financing support, with countries in the Middle East and North Africa to assist governments in managing the economic challenges arising from ongoing transitions there since early 2011.

\section{MODERNIZING THE FINANCING TOOLKIT}

The Executive Board approved a set of reforms during the financial year designed to increase the flexibility and scope of the Fund's financing instruments. The reforms agreed to by the Board were designed to better equip the toolkit to provide liquidity and emergency assistance to the Fund's global membership. The changes will enable the Fund to respond with more flexibility to the diverse liquidity needs of members with sound policies and fundamentals, but nonetheless affected by contagion risks ("crisis bystanders"), and to address urgent financing needs arising in a broader range of circumstances than the natural disasters and post-conflict situations previously covered.

Under the reforms, the Precautionary Credit Line (PCL) was replaced with a more flexible Precautionary and Liquidity Line (PLL). The PLL can be used under broader circumstances, including as insurance against future shocks and as a short-term liquidity window to address the needs of members with sound economic fundamentals and institutional policy frameworks, including crisis bystanders. The Fund's existing policies for emergency assistance (Emergency Natural Disaster Assistance and Emergency Post-Conflict Assistance) were consolidated and replaced with a new Rapid Financing Instrument, which can be used to support a full range of urgent balance of payments needs, including those arising from exogenous shocks.

\section{STRENGTHENING SURVEILLANCE}

Major steps were taken in FY2012 to improve the Fund's surveillance methods and outputs. The Executive Board concluded a comprehensive review of the IMF's surveillance activities - the Triennial Surveillance Review (TSR). While they found that significant progress had been made, since the last TSR in 2008, in the way surveillance is conducted, Executive Directors concurred with the Managing Director's action plan to strengthen it in the following six areas: interconnections, risk assessments, financial stability, external stability, the legal framework, and traction. Of particular note, the Board found that the analysis of external spillovers for the five biggest systemic economies, undertaken for the first time in 2011, had contributed in a useful way to Fund surveillance and recommended that the exercise be repeated prior to further evaluation. The Fund also set out to develop a work plan for financial sector surveillance to lay out the strategic and operational priorities for the Fund's work in this area. In the area of external stability, the Board agreed to continue work to broaden analysis beyond exchange rates to include multilaterally consistent staff assessments of external balances. In terms of the Fund's legal framework for surveillance, the Executive Board began work toward updating the existing legal framework to enable more effective conduct of surveillance, and it was expected that the Board would take this up further in FY2013.

The Fund also issued a new Consolidated Multilateral Surveillance Report in October 2011 and April 2012 to foster discussion among policymakers and strengthen the role of the International Monetary and Financial Committee (IMFC). Executive Directors agreed that the Fund could increase the attention given in its surveillance to inclusive growth, employment, and other social issues that have significant macroeconomic impacts, drawing from the expertise of other institutions. The Fund also focused its work on several broader core areas, including capital flows, modernizing the fiscal framework and debt sustainability analysis, and managing policy challenges for low-income countries in the face of commodity price shocks.

The IMF made further efforts to sharpen its economic risk assessments. In conjunction with the Early Warning Exercise, the Fund continued to strengthen its analytic frameworks tailored to assessing vulnerabilities and emerging risks in advanced economies, emerging markets, and low-income countries. Prepared in collaboration with the Financial Stability Board (FSB) and presented twice a year to the IMFC, the Early Warning Exercise aims to 
identify (1) low-probability but high-impact risks to the global economy, (2) policy actions to mitigate risks and reduce vulnerabilities, and (3) suggestions for further analysis in subsequent rounds of the exercise.

Building on increased awareness, in the wake of the global crisis, of the crucial role played by data in crisis preparedness and prevention, the IMF in FY2012 continued its ongoing efforts to strengthen the quality of data provided by its members and to increase the accessibility of the data it produces and manages. The Eighth Review of the Fund's Data Standards Initiatives was completed in February 2012, and increasing and improving online access was a particular focus during the year.

\section{TECHNICAL ASSISTANCE AND TRAINING}

Amid heavy demand, generous donor contributions enabled the IMF to deliver about 17 percent more technical assistance (TA) in the field in FY2012 than in the previous financial year, serving nearly all of its member countries. As a core function of the IMF, technical assistance reinforces member capacities in the fiscal, legal, monetary/financial markets, and statistics areas. Efforts this financial year focused on helping countries manage the near-term implications of weak world growth, turbulence in Europe, and continued volatility in financial markets. More fundamentally, technical assistance was directed at strengthening policy frameworks and institutions to support sustained growth. TA delivery increased across all areas during the year, with demand for TA on fiscal issues particularly high.

Following a report by a task force charged with assessing the Fund's TA strategy, the IMF announced in early 2012 the decision to merge two existing operational units, the IMF Institute and the Office of Technical Assistance Management, to create the new Institute for Capacity Development. The new department, which began operating in May 2012, provides technical assistance and training to help member countries build capacity and develop key economic and financial institutions.

\section{REFORMING THE FUND TO MEET THE CHANGING PROFILE OF MEMBER COUNTRIES}

As noted on many occasions by the IMF's governing bodies and management, the implementation of approved governance reforms is crucial to ensure an institution that is representative, legitimate, and credible. During FY2012, the Executive Board closely monitored progress in members' acceptance of the quota and governance reform package approved by the Board of Governors in 2010, emphasizing the importance of moving rapidly to ensure implementation of the reforms by the 2012 Annual Meetings. They also initiated a review of the Fund's quota formula, which determines members' quotas.
Ensuring the sufficiency of the IMF's resources to meet potential increases in member needs has been an ongoing concern since the beginning of the global crisis, and Fund efforts in this area continued during FY2012. Resources available through the expanded New Arrangements to Borrow (NAB) were augmented (to nearly SDR 370 billion, ${ }^{3}$ or US\$574 billion, as of the end of the financial year), and the expanded NAB was reactivated twice to ensure ready access to its resources when needed. Member countries pledged, bilaterally, an additional US $\$ 430$ billion in resources in FY2012. Fundraising to boost resources available for assisting low-income countries also continued during the year, and the Executive Board endorsed the use of a portion of the windfall profits from the IMF's recent gold sales, as part of a strategy to raise additional funds to subsidize the interest rate on concessional financing arrangements provided to low-income members.

There were several changes in the Fund's management during the financial year. In late June 2011, the Executive Board selected Christine Lagarde - the first woman named to the top IMF post since the institution's inception in 1944-to serve as IMF Managing Director and Chair of the Executive Board for a five-year term starting that July. Shortly thereafter, David Lipton was appointed as First Deputy Managing Director to replace John Lipsky, and Min Zhu was appointed to the position of Deputy Managing Director.

\section{COLLABORATION AND OUTREACH}

The IMF continued to collaborate with other organizations during the year. Its ongoing work with the Group of Twenty (G-20) advanced and emerging market economies remained of particular significance, and its collaborative efforts with regional financing arrangements, especially in Europe, took on increasing importance in the face of ongoing financial instability. The Fund worked closely with the FSB on risk assessments and data provision issues, and with the World Bank on a day-to-day basis on low-income country issues and financial sector assessments. Also noteworthy was the collaboration between the IMF and the International Labour Organization on issues related to employment creation and social protection floors.

In this spirit, the Fund also continued to place great importance on outreach and engagement with outside stakeholders. Fund outreach provides an opportunity to communicate to the membership the strategic vision for the organization and its key policy priorities; to increase support for policymakers in undertaking national reforms with domestic and global benefits; to strengthen Fund analysis and policy advice by engaging key stakeholders in member countries on issues of concern to them; and to emphasize to members, especially those hard hit by the crisis, the Fund's commitment to providing needed support. 


\title{
2
}

\author{
GLOBAL ECONOMIC AND \\ FINANCIAL DEVELOPMENTS
}

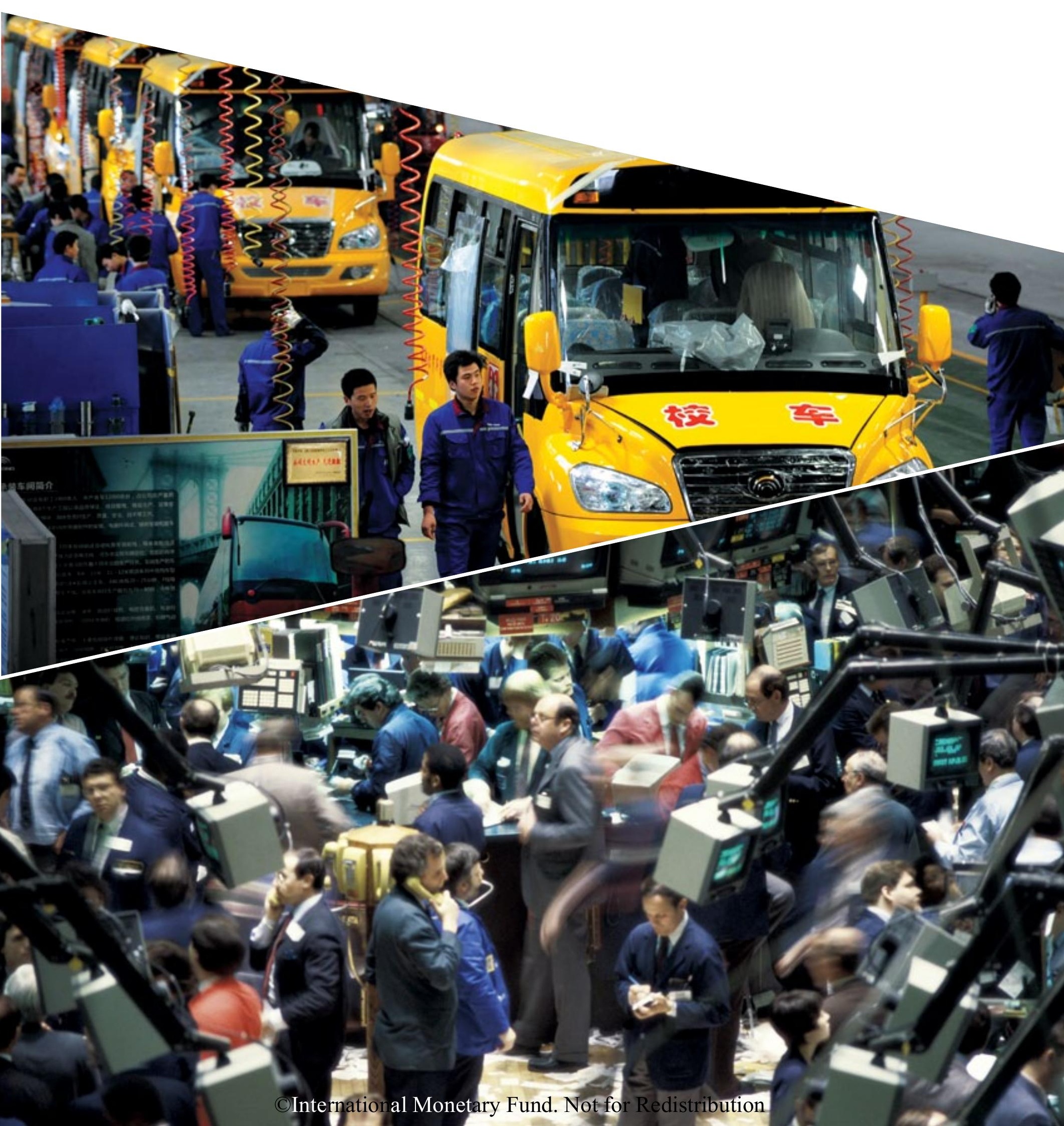




\section{GLOBAL ECONOMIC AND FINANCIAL DEVELOPMENTS}

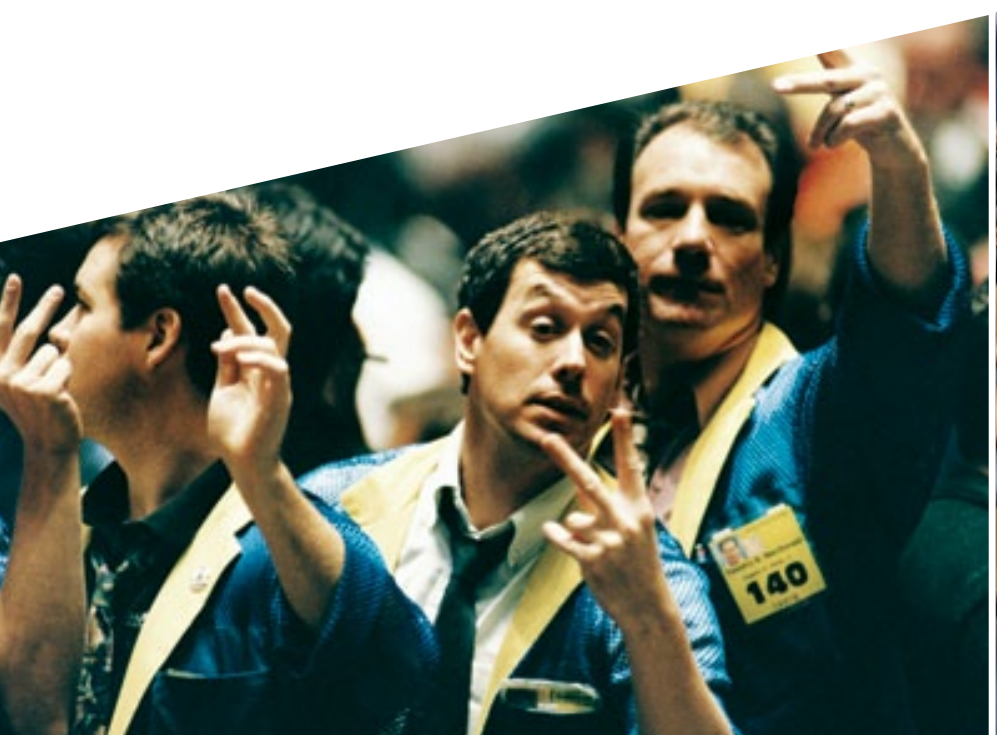

After a major setback in late 2011, global economic prospects gradually improved in early 2012, but concerns over the strength of the recovery resurfaced in the second quarter. Stronger activity in the United States and policies in the euro area in response to its deepening economic crisis helped to address the sharp deterioration in financial conditions and boost market confidence in the first few months of 2012 . However, downside risks remained elevated at the end of FY2012, and markets were jittery as concerns about sovereign debt in parts of Europe and pressure on the European banking sector resurfaced.

With markets volatile, the outlook remained fragile as FY2012 closed. Policymakers needed to continue implementing the fundamental fiscal and structural reforms required to achieve healthy and sustainable growth over the medium term. The challenge for advanced economies was how to do this while supporting still-weak growth in the near term. In the euro area, further progress was needed to create a stronger currency union, including steps to intensify fiscal coordination and ex ante fiscal risk sharing, strengthen banking systems, and reduce the dependency linkages between banks and sovereign financing. Emerging market and developing economies faced the challenge of calibrating macroeconomic policies to counter global downside risks and support growth while, in some cases, efforts were needed to keep overheating pressures from reaching excessive levels.

\section{TWO STEPS FORWARD, ONE STEP BACK}

The world economy rebounded gradually during the first quarter of 2012 after suffering a major setback in late 2011. Concerns about financial stability in the euro area and intense market stress threatened to pitch Europe, and possibly all advanced economies, into another deep recession. However, a more robust policy response in Europe helped to stabilize markets, and activity in the United States continued to improve. In addition, most emerging market economies and low-income countries maintained solid growth rates. However, ongoing economic and financial difficulties in the euro area, combined with political uncertainties there, continued to pose a critical source of vulnerability to the global recovery as of the end of FY2012.

Indeed, the financial market turbulence during FY2012 highlighted the risk of adverse, self-fulfilling shifts in market sentiment. These can push fragile economies rapidly into a bad equilibrium of rising yields, a bank funding squeeze, and tighter credit growth, with adverse feedback to the real economy. With decisive action by the European Central Bank to provide large amounts of long-term liquidity to banks, fiscal adjustment and structural reforms by key euro area members, improvements in European Union governance structures, and agreement on the details of the European emergency financing facilities, the policy response in Europe strengthened in the early part of 2012. Other central banks also took policy steps to ease monetary conditions, and credit risks retreated. However, 
risks to global financial stability remained elevated. Bank lending standards had tightened, broader financial conditions had deteriorated, and bond markets remained fragile and volatile.

This was (and is) the legacy of the Great Recession and the financial crisis. As suggested by historical experience, the process of deleveraging takes time and tends to dampen economic activity. The close of FY2012 found many economies still weighed down by high debt burdens across multiple sectors, so balance sheet repair extended across governments, corporations, and households, often simultaneously. In addition, many countries with large external debts confronted the challenge of rebalancing in the face of serious competitiveness problems and subdued external demand. Policymakers needed to design a careful and sophisticated mix of financial, macroeconomic, and structural policies that would ensure a smooth deleveraging process, support growth, and facilitate rebalancing.

Against this background, the overall outlook remained fragile at the end of FY2012. In the April 2012 World Economic Outlook, global growth was projected to drop from about 4 percent in 2011 to $3 \frac{1}{2}$ percent in 2012 , ticking up slowly to 4 percent again in 2013. The euro area was projected to go into a mild recession in 2012 as a result of the sovereign debt crisis, the effects of bank deleveraging on the real economy, and the impact of fiscal consolidation. In the advanced economies as a group, output was expected to expand by only $1 \frac{1}{2} 2$ percent in 2012 and 2 percent in 2013. Job creation in these economies would, it was thought, remain sluggish, and unemployment was expected to remain near 8 percent.

In emerging market and developing economies, real gross domestic product (GDP) growth was projected to slow slightly to $53 / 4$ percent in 2012 , from 6.2 percent in 2011 , before rebounding to 6 percent in 2013. As FY2012 was winding down, these economies continued to reap the benefits of strong macroeconomic frameworks and earlier structural reform, although domestic vulnerabilities had been gradually building after a decade of strong growth supported by rapid credit growth or high commodity prices.

Risks to the outlook remained firmly on the downside. First, ongoing concerns about the euro area debt crisis continued to undermine financial market stability and remained the single biggest source of risk to the world economy. A sharp escalation in the crisis could trigger a generalized flight from risk that would have a very negative global impact. Excessive deleveraging in European banks, for example, could expose vulnerabilities in emerging markets, triggering renewed portfolio outflows and upsetting domestic financial stability. Second, geopolitical uncertainty could raise oil prices sharply and undermine world growth. Over the medium term, risks relating to persistently weak activity and high public debts and deficits in advanced economies could undercut support for fiscal adjustment and trade and financial integration.

\section{GETTING TWO STEPS AHEAD}

Looking ahead from the vantage point of the end of FY2012, governments would need to strengthen policies to solidify the weak recovery and contain the downside risks. This would involve further efforts to address the euro area crisis, a measured approach to fiscal consolidation in response to weaker activity, continued accommodative monetary policies, and ample liquidity to the financial sector. Over the medium term, the challenge would be to improve the weak growth outlook in the major advanced economies.

Starting with the euro area, the authorities needed to build on the important measures taken in FY2012 to strengthen the crisis response mechanism. Fiscal consolidation needed to continue steadily but be structured to avoid an excessive decline in demand in the near term. There could be room for further monetary easing, and the banks would need to be recapitalized, with a focus on avoiding destructive deleveraging of the banking system to promote an adequate flow of credit to the private sector. Over the medium term, changes were needed to remedy weaknesses in the design of the currency union that contributed to the crisis: a better mechanism to deliver responsible and consistent fiscal policies, including the possibility of having EU institutions actively involved in national budgetary plans; expansion in fiscal risk sharing to ensure that problems in one country do not develop into a costly financial crisis in another; a more integrated euro area financial system that includes common supervision and regulation, deposit insurance, and bank resolution; and measures across the region to narrow the structural reform gap, including in labor markets.

In other advanced economies, there remained an urgent need for strong, sustainable fiscal consolidation plans over the medium term that would put public debt on a clear sustainable path, particularly in Japan and the United States. Medium-term fiscal plans needed to involve strengthening fiscal institutions and reforming entitlement programs, for example, linking retirement age to life expectancy or improving cost incentives in the health care sector. Articulating plans to tackle these issues would demonstrate policymakers' willingness and ability to act, thereby helping to rebuild market confidence in the sustainability of public finances early in the process. At the same time, given the weak growth prospects, those with fiscal policy room, in terms of the strength of their fiscal accounts and credibility with markets, could reconsider the pace of consolidation so that growth was not adversely affected. Others could let automatic stabilizers operate freely for as long as they could readily finance higher deficits.

Aside from fiscal policy, the most important priorities remained, as of the end of FY2012, the regulation and supervision of the global financial sector, and productivity-enhancing reforms to boost potential output. In the United States, a more forceful approach might be needed to address problems in real estate markets, and accelerate the repair of household balance sheets. 
Unemployment remained unacceptably high. More than 200 million people worldwide were out of work at the end of FY2012, and in some countries in southern Europe, half of all young people were unable to find a job. Structural reforms needed to include income support and training for the unemployed to help raise productivity and increase labor force participation. Measures that would encourage bank lending to small and medium-sized enterprises, which account for a large share of employment, would also help. The challenge for emerging market and developing economies was how to manage macroeconomic policies to address, in some cases, the downside risks from weak growth in advanced economies and financial market volatility, while in other cases keeping overheating pressures in check. Depending on the specifics of each case, this could involve measures to respond to lower domestic and external demand, preparing to cope with adverse spillovers from advanced economies and capital outflows, rebuilding fiscal buffers and reserves, removing monetary accommodation, and strengthening prudential policies and frameworks. In low-income countries, fiscal policy needed to contain the damage to public balance sheets by targeting subsidies only to the most vulnerable households.

The final months of FY2012 confirmed that the successful international cooperation that drove the coordinated policy response in the early days of the financial crisis was still needed to secure lasting growth. Fiscal consolidation alone could not treat the economic malaise and could, in the face of low growth, lead perversely to a worsening of debt ratios in the short term. The drop in consumption among countries with large external deficits had not been offset by stronger consumption in surplus countries, so the world had experienced a net loss of demand and growth. Countries with high saving rates needed to seek to address distortions that suppress consumption, while countries with excess credit-driven growth needed to rein in credit growth and demand. Supported-as appropriate-by more marketdetermined exchange rates, this would help sustain growth prospects in these countries and the rest of the world.

Policy cooperation was also important to ensure a safe and stable financial system that served the interests of households and business. At the global level, new regulations needed to be implemented consistently across borders. Further efforts were also essential to resolve problems in connection with institutions considered too big or too complex to fail, the shadow banking system, and cross-border issues related to bank resolution and collaboration between bank supervisors. Bank regulation and supervision had become a global exercise that could only be pursued collaboratively, lest institutions engage in regulatory arbitrage, as they had done in the past, and undermine the prudential controls and safeguards embodied in new regulations.

\section{CInternational Monetary Fund. Not for Redistribution}




\section{(2) SUPPORTING GLOBAL (b) RECOVERY}

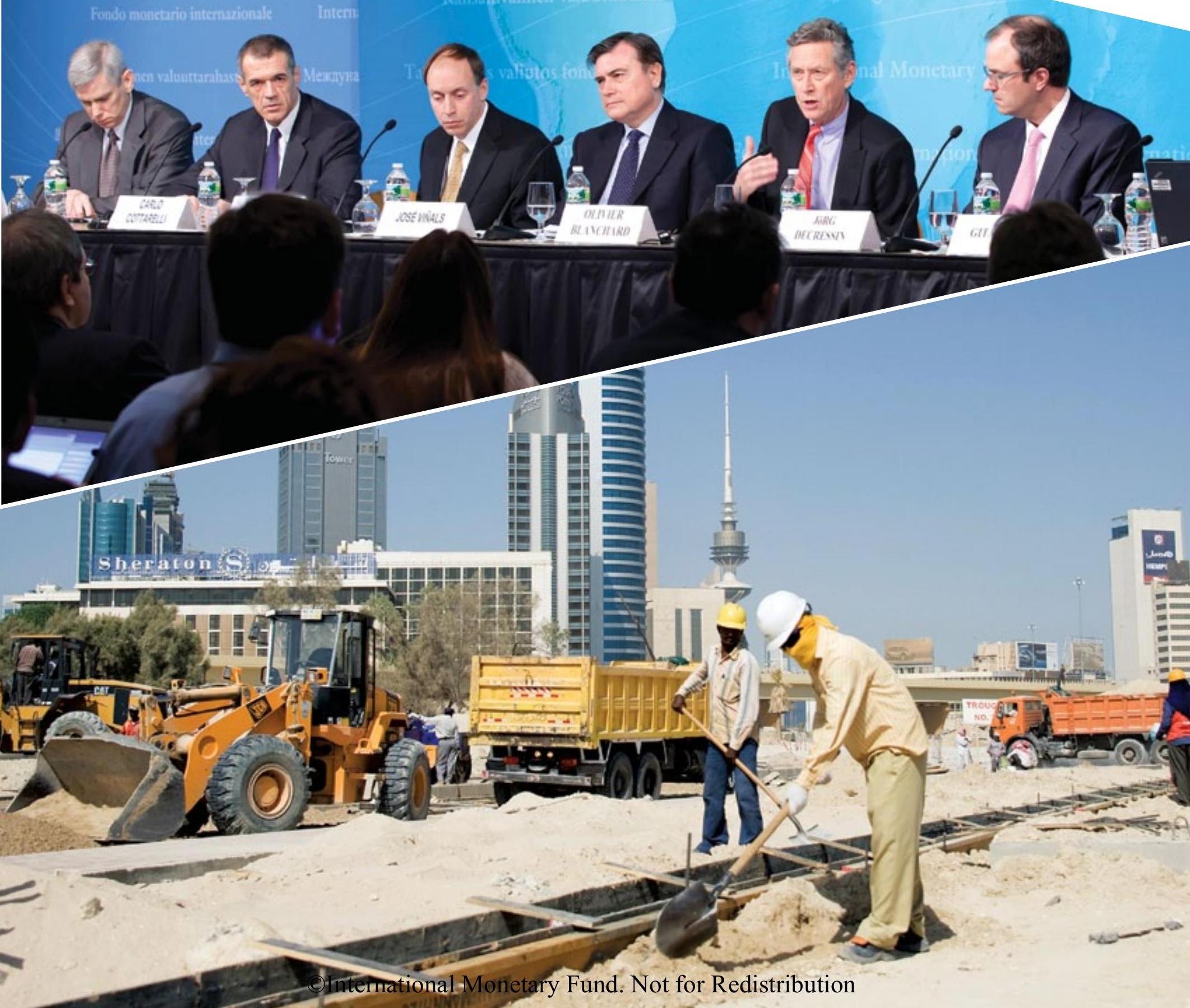




\section{SUPPORTING GLOBAL RECOVERY

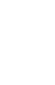

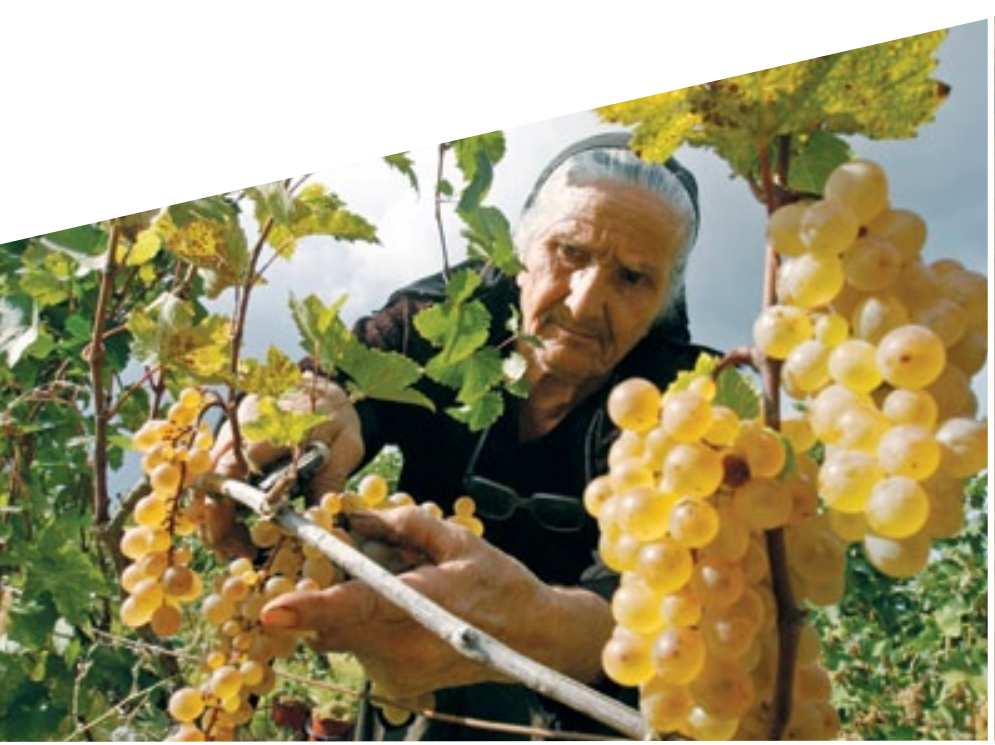

\section{FINANCIAL SUPPORT TO COUNTRIES DURING THE CRISIS}

\section{Global safety net}

Financing activities in 2012

The IMF continued in FY2012 to respond flexibly to members' financing needs in an environment of heightened global uncertainty. The demand for Fund resources remained strong and commitments increased further, although at a slower pace compared to the previous year.

In January 2012, the Executive Board reviewed the adequacy of the IMF's resources for providing financing to members. ${ }^{4}$ Following the Board's discussion, the Managing Director observed that it had provided an opportunity to assess whether the Fund's resources were sufficient to fulfill its mandate and to play a full and constructive role in securing global stability. She noted that in the discussion, many Executive Directors had stressed the necessity and urgency of collective efforts to contain the debt crisis in the euro area and protect economies around the world from spillovers and excessive output/income contractions. In this context, Executive Directors welcomed the recently announced commitment of European members to contribute to the Fund's resources, while stressing the importance of European firewalls and other policies being sufficiently strong to respond to the crisis in the euro area.
Going further, during the 2012 Spring Meetings, members committed to take the necessary actions to secure global financial stability. Together with the G-20, the IMFC reached agreement to enhance IMF resources for crisis prevention and resolution. A significant number of countries made firm commitments to increase IMF resources by more than US $\$ 430$ billion (see Chapter 5) in addition to the quota increase under the 2010 quota and governance reform. These resources will be available for the full membership of the IMF, and not earmarked for any particular region. The commitments, coming after national and regional structural, fiscal, and monetary actions were put in place in the early months of 2012, showed the international community's commitment to safeguarding global financial stability and putting the global economic recovery on a sounder footing.

Member countries may request IMF financial assistance to meet their net balance of payments needs and maintain adequate reserve buffers. IMF financing is usually provided under an "arrangement," in support of a member's economic program that includes adjustment policies and measures the member has committed to implementing to resolve its balance of payments problem. Over the years, the IMF has approved various policies setting forth financing instruments and facilities, some of which are flexible enough to assist with addressing any type of balance of payment need, whereas others are tailored to address the specific circumstances of its diverse membership. Low-income countries may borrow on concessional terms through a number of facilities; during FY2012, most IMF concessional financing carried an interest rate of zero, which will be in effect until the end of 2013. Nonconces- 
sional financing is also provided, through additional instruments and facilities; all nonconcessional instruments and facilities are subject to the IMF's market-related interest rate, known as the "rate of charge" (based on the SDR interest rate, which is revised weekly), ${ }^{5}$ and large amounts financed (above certain limits) carry a surcharge. Depending on the nature of a member's balance of payments need, an arrangement can be approved on a precautionary basis (which is not followed by an immediate disbursement) or as a disbursing one (under which the approved financing is generally released in phased installments as the program is implemented). ${ }^{6}$ An IMF member's access to Fund resources is determined in terms of its quota (see Chapter 5) and is subject to "access limits" (see Table 3.1).

By far the largest share of transactions between the IMF and its membership are handled through the General Resources Account (GRA), a pool of currencies and reserve assets built up from members' quotas and from bilateral and multilateral borrowing arrangements. For arrangements through the GRA, access limits may be exceeded in exceptional circumstances ("exceptional access"), provided the substantive criteria set forth in the exceptional access policy are met, and subject to early Board involvement. For arrangements through the PRGT, access to Trust resources in excess of normal limits is subject to special procedures, most notably, early Board involvement.

\section{Nonconcessional financing}

In FY2012, the Executive Board approved seven arrangements under the Fund's nonconcessional financing facilities, for a gross total of SDR 52.60 billion $^{7}$ (US\$81.62 billion). More than 90 percent of the new gross commitments in FY2012 (SDR 47.5 billion, or US\$73.36 billion) was for two arrangements under the Extended Fund Facility (EFF) for Greece and Portugal (see Box 3.1). Four Stand-By Arrangements (SBAs) were also approved, of which one (for St. Kitts and Nevis) involved exceptional access and two (for Serbia and Georgia) ${ }^{8}$ were treated, upon approval, as precautionary. In addition, a new SDR 3.87 billion (US\$6.22 billion) arrangement under the Flexible Credit Line was approved for Colombia, succeeding an earlier FCL arrangement with lower access that expired in May 2011.

\section{Box 3.1}

\section{Fund engagement in the euro area}

The IMF's involvement in the euro area continued in FY2012 with new arrangements approved for Greece and Portugal and ongoing policy efforts under the existing extended arrangement under the Extended Fund Facility (EFF) for Ireland.

Long-standing structural problems - including low productivity, weak competitiveness, and high private debt-have severely undermined growth in Portugal and given rise to large external and fiscal imbalances. In May 2011, the Executive Board approved a three-year extended arrangement of approximately SDR 23.7 billion ( $€ 26$ billion) under the EFF for Portugal in support of the authorities' economic adjustment and growth program. The arrangement for Portugal, part of a three-year, $€ 78$ billion cooperative package of financing with the European Union, entails exceptional access to IMF resources, amounting to 2,306 percent of Portugal's quota. The authorities' program focuses on structural reforms to boost growth and employment; an ambitious but balanced fiscal stabilization path, supported by structural fiscal reform; and safeguards to ensure financial stability and prevent a protracted credit contraction. The third review of Portugal's performance under the extended arrangement was completed successfully in April 2012; total disbursements under the arrangement through the end of FY2012 were approximately SDR 15.9 billion ( $€ 18.6$ billion).

A second new program in the euro area during the financial year was supported by the four-year, SDR 23.7853 billion ( $€ 28.0$ billion) extended arrangement under the EFF for Greece approved in March 2012, upon cancellation by the Greek authorities of an earlier three-year Stand-By Arrangement (SBA). Like the arrangement for
Portugal, that for Greece also entails exceptional access to IMF resources, amounting to 2,158.8 percent of Greece's quota. The Greek authorities' economic program aims, over time, at restoring competitiveness, growth, and fiscal sustainability and securing financial stability. While building on progress made under the SBA, the authorities recalibrated their program strategy to place additional emphasis on the implementation of structural reforms to accelerate economic growth and employment. Official sector support for the Greek program entails $€ 130$ billion in new financing through 2014 , in addition to the remainder of the financing support under an earlier program of $€ 34$ billion, and an additional $€ 8$ billion from the IMF in 2015 and the first quarter of 2016. The first disbursement, in an amount equivalent to SDR 1.3991 billion ( $€ 1.65$ billion), was made upon the program's approval in March. The Fund's peak exposure will remain broadly unchanged relative to that under the SBA.

Ireland's program implementation (now in its second year) continues to be strong. The Irish authorities have advanced wide-ranging reforms to restore the health of the country's financial system so it can support economic recovery. Major progress in downsizing the country's banking system has been made, and fiscal consolidation remains on track. The Executive Board completed the fifth review under Ireland's extended arrangement under the EFF in February 2012, enabling the disbursement of SDR 2.8 billion ( $€ 3.2$ billion), bringing total disbursements under the arrangement to SDR 13.8 billion (about $€ 16.1$ billion). The three-year, SDR 19.5 billion (about $€ 22.6$ billion) arrangement for Ireland, which was approved in December 2010, is a part of an $€ 85$ billion financing package also supported by Ireland's European partners and Ireland's own contributions. 
Table 3.1

\section{IMF financing facilities}

$\begin{array}{llc}\begin{array}{l}\text { Credit facility } \\ (\text { year adopted })^{1}\end{array} & \text { Purpose } & \text { Conditions }\end{array}$

\section{CREDIT TRANCHES AND EXTENDED FUND FACILITY³}

Stand-By

Arrangements (1952)

Flexible Credit Line

(FCL) (2009)

Extended Fund

Facility (EFF) (1974)

(Extended

Arrangements)

Precautionary and

Liquidity Line (PLL)

(2011)
Medium-term assistance for countries with balance of payments difficulties of a short-term character.

Flexible instrument in the credit tranches to address all balance of payments needs, potential or actual.

Longer-term assistance to support members' structural reforms to address balance of payments difficulties of a long-term character.

Instrument for countries with sound economic fundamentals and policies.
Adopt policies that provide confidence that the member's balance of payments difficulties will be resolved within a reasonable period.

Very strong ex ante macroeconomic fundamentals, economic policy framework, and policy track record.

Adopt up to four-year program, with structura agenda, with annual detailed statement of policies for the next 12 months.

Strong policy frameworks, external position, and market access, including financial sector soundness.
Quarterly purchases (disbursements) contingent on observance of performance criteria and other conditions.

Approved access available up front throughout the arrangement period, subject to a midterm review after one year.

Quarterly or semiannual purchases (disbursements) contingent on observance of performance criteria and other conditions.

Large front-loaded access, subject to semiannual reviews (for one- to two-year PLL).

\section{SPECIAL FACILITIES}

Rapid Financing Instrument (RFI) (2011)
Rapid financial assistance to all member countries facing an urgent balance of payments need.
Efforts to solve balance of payments difficulties (may include prior actions).
Outright purchases without the need for full-fledged program or reviews.

FACILITIES FOR LOW-INCOME MEMBERS UNDER THE POVERTY REDUCTION AND GROWTH TRUST

Extended Credit Facility (ECF) (2010)

Medium-term assistance to address protracted balance of payments problems.

Standby Credit Facility (SCF) (2010)

Rapid Credit Facility (RCF) (2010)
To resolve short-term balance of payments and precautionary needs.

Rapid assistance for urgent balance of payments needs where an upper-credit-tranche-quality program is not needed or feasible.
Adopt three-year ECF arrangements. ECF-supported programs are based on a Poverty Reduction Strategy Paper (PRSP) prepared by the country in a participatory process and integrating macroeconomic, structural, and poverty reduction policies.

Adopt 12- to 24-month SCF arrangements.

No review-based program necessary or ex post conditionality.
Semiannual (or occasionally quarterly) disbursements contingent on observance of performance criteria and reviews.

Semiannual (or occasionally quarterly) disbursements contingent on observance of performance criteria and reviews (if drawn).

Usually in a single disbursement.

\footnotetext{
1 Except for that financed by the Poverty Reduction and Growth Trust, the IMF's lending is primarily financed from the capital subscribed by member countries; each country is assigned a quota that represents its financial commitment. A member provides a portion of its quota in foreign currencies acceptable to the IMF-or Special Drawing Rights (SDRs) - and the remainder in its own currency. An IMF loan is disbursed or drawn by the borrower's purchasing foreign currency assets from the IMF with its own currency. Repayment of the loan is achieved by the borrower's repurchasing its currency from the IMF with foreign currency. ECF, RCF, and SCF concessional lending is financed by a separate Poverty Reduction and Growth Trust.

2 The rate of charge on funds disbursed from the General Resources Account (GRA) is set at a margin over the weekly interest rate on SDRs. The rate of charge is applied to the daily balance of all outstanding GRA drawings during each IMF financial quarter. In addition, a one-time service charge of 0.5 percent is levied on each drawing of IMF resources in the GRA, other than reserve tranche drawings. An up-front commitment fee ( 15 basis points on committed amounts of up to 200 percent of quota; 30 basis points for amounts in excess of 200 percent and up to 1,000 percent of quota; and 60 basis points for amounts in excess of 1,000 percent of quota) applies to the amount that may be drawn during each (annual) period under a Stand-By, Flexible Credit Line, Precautionary and Liquidity Line, or Extended Arrangement; this fee is refunded on a (1) proportiona interest rate mechanism was established in 2009 linking the concessional interest rates to the SDR interest rate and regular reviews. At these reviews, the applicable interest rates are set as follows: if the average SDR interest rate observed in the most recent 12-month period is less than 2 percent, the interest rate for ECF and RCF loans shall be set at 0 percent per year, and at 0.25 percent per year for SCF loans; if the average SDR interest rate is 2 percent or more, up to 5 percent, the interest rate for ECF and RCF
}

\section{CInternational Monetary Fund. Not for Redistribution}


Annual: $200 \%$ of quota; cumulative: $600 \%$ of quota.

No preset limit.

Annual: $200 \%$ of quota; cumulative: $600 \%$ of quota.

$250 \%$ of quota for six months; $500 \%$ of quota available upon approval of one- to two-year arrangements; total of $1,000 \%$

of quota after 12 months of

satisfactory progress.
Rate of charge plus surcharge (200 basis points on amounts above $300 \%$ of quota; additional 100 basis points when outstanding credit remains above $300 \%$ of quota for more than three years). ${ }^{4}$

Same as above.

$31 / 4-5$

Quarterly

Same as above.

$41 / 2-10$

Semiannua

Same as above.
Quarterly

$31 / 4-5$
$3 \frac{1}{1} 4-5$

Quarterly

$31 / 4-5$

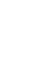

Quarterly


Figure 3.1

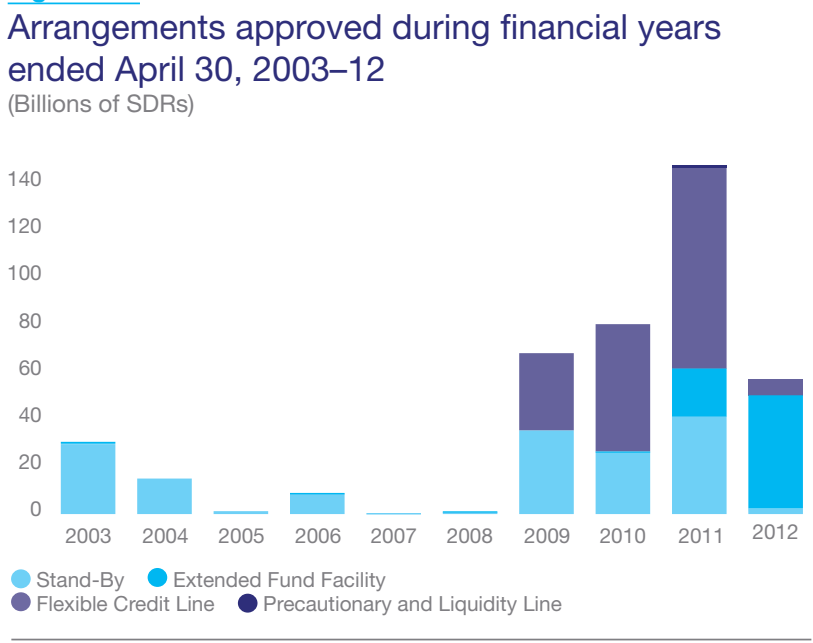

Source: IMF Finance Department.
Figure 3.2

Nonconcessional financing outstanding, FY2003-12 (Billions of SDRs)

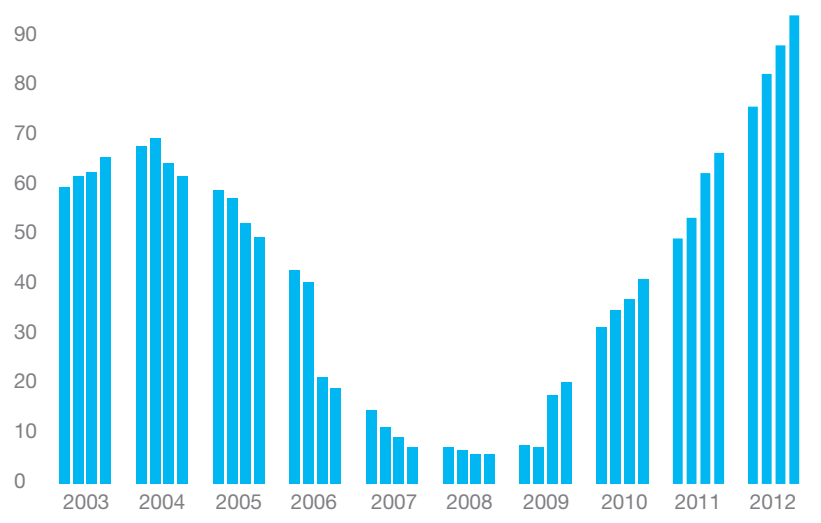

Source: IMF Finance Department.
In total, by end-April 2012, purchases $^{9}$ from the GRA reached SDR 32.2 billion (US $\$ 49.9$ billion), with purchases by the three euro area program countries (Greece, Ireland, and Portugal) accounting for more than 95 percent of the total. Repurchases for the period amounted to SDR 3.6 billion.

Box 3.2

\section{Support to Arab transition countries}

The Arab countries in transition are undergoing historic changes that offer opportunities for a more prosperous future but also pose significant economic challenges in the near term. The IMF is supporting these countries through policy advice, capacity building, and financial assistance.

The IMF has been tailoring its policy advice to focus on issues of importance to the region. In addition to the IMF's focus on macroeconomic and financial stability, this includes greater emphasis on promoting inclusive growth, with a focus on topics such as tackling unemployment and improving social protection. Given the IMF's core macroeconomic expertise, it is cooperating with other international organizations, such as the World Bank and the International Labour Organization, which have greater expertise in these areas.

IMF capacity-building efforts in the region have been refocused on promoting strong institutions, producing good data, and
Table 3.1 provides general information about the IMF's financing instruments and facilities, and Table 3.2 and Figure 3.1 detail the arrangements approved during the year, with Figure 3.2 offering information on financing amounts outstanding over the last 10 years. making fiscal policies more equitable. To those ends, efforts under way have included, for example, technical assistance in Egypt to improve tax equity, in Jordan to reform fuel subsidies, in Libya to improve public financial management, in Morocco and Tunisia to strengthen the financial sector, and in Yemen to improve customs administration. The Middle East Technical Assistance Center provides hands-on training and facilitates peer discussions in these areas. The new IMF-Middle East Center for Economics and Finance in Kuwait provides training on the formulation and implementation of macroeconomic policies.

With regard to financial assistance, the IMF has upgraded its lending toolkit in part to address the region's needs, approved a US $\$ 93.75$ million Rapid Credit Facility purchase for Yemen in April 2012, has been in discussions with Egypt on a possible Stand-By Arrangement, and is engaging with other countries on financing needs and possible support.

\section{CInternational Monetary Fund. Not for Redistribution}


Table 3.2

Arrangements under main facilities approved in FY2012

(Millions of SDRs)

\begin{tabular}{lllr} 
Member & Type of arrangement & Effective date & Amount approved \\
\hline NEW ARRANGEMENTS & & \\
Colombia & 24-month Flexible Credit Line & May 6, 2011 & $3,870.0$ \\
Portugal & 36-month Extended Fund Facility & May 20, 2011 & $23,742.0$ \\
St. Kitts and Nevis & 36-month Stand-By & July 27, 2011 & 52.5 \\
Serbia & 18-month Stand-By & September 29, 2011 & 935.4 \\
Greece & 48-month Extended Fund Facility & March 15, 2012 & $23,785.3$ \\
Georgia & 24-month Stand-By & April 11, 2012 & 125.0 \\
Kosovo & 20-month Stand-By & April 27, 2012 & 91.0 \\
& & &
\end{tabular}

Total

$52,601.2$

Source: IMF Finance Department

resources involves a strategy whereby members indicate to the Fund that amounts in proportion to their quota shares should be transferred by the IMF or otherwise provided for PRGT subsidies. In February 2012, the Board approved a distribution to IMF members of SDR 700 million (US\$1.1 billion) from the Fund's general reserve, subject to the Fund's receiving satisfactory assurances from members that at least 90 percent of the amount distributed (that is, SDR 630 million, or US\$977 million) will be made available for PRGT subsidy resources. As of end-April 2012, 69 of the IMF's 188 member countries, including 27 African countries, representing the aggregate amount of SDR 340.38 million (US\$527.76 million), had indicated that they would support subsidizing lending to low-income countries.

Evaluation of and modifications to the IMF's financing framework

At the start of the global crisis, the IMF embarked on a reform process to strengthen its toolkit for financing from the GRA, with the objective of increasing the usefulness of Fund instruments and facilities in meeting members' financing needs, while preserving the simplicity and coherence of the financing framework and safeguarding Fund resources. Reforms in 2009 (creation of the FCL) and 2010 (enhancement of the FCL and creation of the PCL) significantly improved the Fund's ability to provide financing for crisis prevention and resolution.

Review of Flexible and Precautionary Credit Lines and Reform of the Financing Toolkit

In November 2011, in conjunction with its first review of the FCL and PCL instruments, the Executive Board approved a set of reforms designed to bolster the flexibility and scope of the Fund's financing toolkit to provide liquidity and emergency assistance more effectively to the Fund's global membership.
These reforms are expected to enable the Fund to respond better to the diverse liquidity needs of members with sound policies and fundamentals, including those affected during periods of heightened economic or market stress - crisis bystanders (that is, countries with relatively strong fundamentals and solid policy track records for which the likelihood of an idiosyncratic crisis would normally be low) — and to address urgent financing needs arising in a broader range of circumstances than the natural disasters and post-conflict situations previously covered under special policies.

Under the reforms, and based on the outcome of the Board's review of the decision establishing it, the PCL was replaced with a more flexible Precautionary and Liquidity Line. The PLL can be used under broader circumstances than could the PCL, including through a new "short-term liquidity window." Under that window, financing (up to 250 percent of quota) is provided through a PLL arrangement of a six-month duration, available to qualifying members that have an actual or potential short-term balance of payments need such that they can be generally expected to make credible progress in addressing their vulnerabilities during the arrangement. In this window, and under exceptional circumstances in which a member is experiencing, or has the potential to experience, larger short-term balance of payments needs due to the impact of exogenous shocks, including heightened regional or global stress conditions, access is subject to a higher limit: 500 percent of quota, net of scheduled PLL repurchases, per arrangement, as insurance against future shocks and as a short-term liquidity window. The Fund's existing policies for emergency assistance (Emergency Natural Disaster Assistance and Emergency Post-Conflict Assistance) were consolidated and replaced with a new Rapid Financing Instrument, which can be used to support a full range of urgent balance of payments needs, including those arising from exogenous shocks. Box 3.3 provides the essentials of these two new financing instruments.

\section{CInternational Monetary Fund. Not for Redistribution}


Box 3.3

\section{Key elements of the new instruments}

Precautionary and Liquidity Line

-Qualification criteria remain the same as under the PCL. A member must be assessed as having sound economic fundamentals and institutional policy frameworks, having a track record of implementing sound policies, and remaining committed to maintaining such policies in the future.

-A member can seek support when it has either a potential or an actual balance of payments need at the time of approval of the arrangement (rather than only a potential need, as was required under the PCL).

-Under the liquidity window, allows for approval of six-month arrangements to meet short-term balance of payments needs. Access under a six-month arrangement would not exceed 250 percent of a member's quota, which could be augmented to a maximum of 500 percent in exceptional circumstances, as decided by the Executive Board on a case-by-case basis.

-Under the standard window, allows for approval of a 12- to 24-month arrangement, with maximum access upon approval equal to 500 percent of a member's quota for the first year and up to 1,000 percent of quota for the second year (the latter of which could also be brought forward to the first year where needed, following a Board review). As under the PCL, arrangements of these durations include Executive Board reviews every six months.

\section{Rapid Financing Instrument}

- Broadens coverage of urgent balance of payments needs beyond those arising from natural disasters and post-conflict situations and can also provide a framework for policy support and technical assistance.

- Funds are available immediately, upon approval, with access limited to 50 percent of the member's quota annually and to 100 percent on a cumulative basis.

- Member must outline its policy plans to address its balance of payments difficulties, and the IMF must assess that the member will cooperate in finding solutions for these difficulties.
Figure 3.3

\section{Concessional financing outstanding, FY2003-12 (Billions of SDRs)}

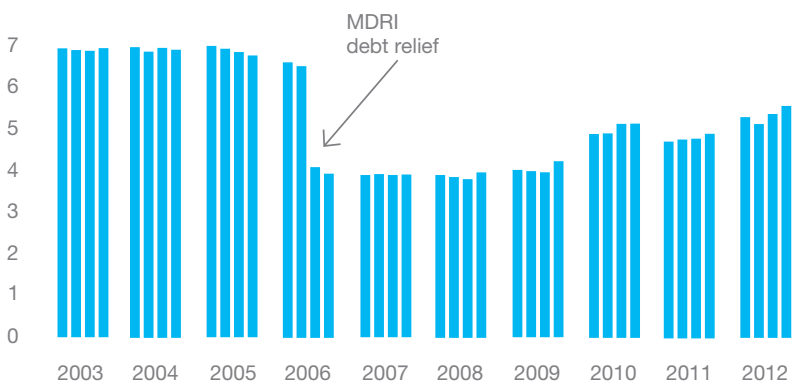

Source: IMF Finance Department

Note: MDRI: Multilateral Debt Relief Initiative.

In their November 2011 discussion, most Executive Directors endorsed the main findings of the IMF staff's review of the FCL and PCL. ${ }^{15}$ Executive Directors supported the staff's proposals to enhance transparency in the assessments of access under FCL and PLL arrangements, which would facilitate comparison and evenhandedness across arrangements. They saw merit in linking the assessment of balance of payments needs in each case more closely with adverse scenarios, which would help guide reserve use assumptions - carefully anchored on measures of reserve needs that are relevant for the particular country.

Executive Directors generally supported the greater focus proposed by the staff on qualitative and forward-looking factors embedded in the FCL/PLL qualification frameworks. They noted that access under the FCL and PLL instruments is a temporary supplement to reserves during periods of heightened risks. They reaffirmed the normal expectation of reduced access under successor FCL arrangements whenever improvements in official and private financing prospects have reduced the member's potential or actual balance of payments needs in a sustained manner by the time the successor arrangement is requested, and agreed that the same expectation would apply to successor PLL arrangements.

Executive Directors underlined the importance of appropriate ex ante and ex post conditionality in regard to the PLL. They welcomed procedures for early Board involvement that would be applicable to all PLL arrangements, irrespective of access or duration. They noted the staff's assessment that the proposed reforms might increase up-front calls on Fund resources, but that the net effect was likely to be relatively limited. 
Table 3.3

Arrangements approved and augmented under the Poverty Reduction and Growth Trust in FY2012 (Millions of SDRs)

\begin{tabular}{|c|c|c|}
\hline Member & Effective date & Amount approved \\
\hline \multicolumn{3}{|c|}{ NEW THREE-YEAR EXTENDED CREDIT FACILITY ARRANGEMENTS } \\
\hline Afghanistan & November 14, 2011 & 85.0 \\
\hline Bangladesh & April 11, 2012 & 640.0 \\
\hline Burundi & January 27, 2012 & 30.0 \\
\hline Côte d'Ivoire & November 4, 2011 & 390.2 \\
\hline Guinea & February 24, 2012 & 128.5 \\
\hline Kyrgyz Republic & June 20, 2011 & 66.6 \\
\hline Mali & December 27, 2011 & 30.0 \\
\hline Niger & March 16, 2012 & 79.0 \\
\hline Subtotal & & $1,449.3$ \\
\hline \multicolumn{3}{|c|}{ AUGMENTATIONS OF EXTENDED CREDIT FACILITY ARRANGEMENTS ${ }^{1}$} \\
\hline Burundi & July 13, 2011 & 5.0 \\
\hline Djibouti & February 6, 2012 & 9.5 \\
\hline Kenya & December 9, 2011 & 162.8 \\
\hline Lesotho & April 9, 2012 & 8.7 \\
\hline Liberia & June 27, 2011 & 8.9 \\
\hline Mali & June 13, 2011 & 25.0 \\
\hline Subtotal & & 219.9 \\
\hline \multicolumn{3}{|c|}{ NEW STANDBY CREDIT FACILITY ARRANGEMENTS } \\
\hline Georgia & April 11, 2012 & 125.0 \\
\hline Solomon Islands & December 6, 2011 & 5.2 \\
\hline Subtotal & & 130.2 \\
\hline \multicolumn{3}{|c|}{ DISBURSEMENTS UNDER RAPID CREDIT FACILITY² } \\
\hline Côte d'lvoire & July 19, 2011 & 81.3 \\
\hline Dominica & January 19, 2012 & 2.1 \\
\hline St. Vincent and the Grenadines & August 3, 2011 & 1.2 \\
\hline Yemen & April 17, 2012 & 60.9 \\
\hline Subtotal & & 145.5 \\
\hline
\end{tabular}

\begin{tabular}{ll}
\hline Total & $1,944.9$
\end{tabular}

Source: IMF Finance Department.

1 For augmentation, only the amount of the increase is shown.

2 Rapid Credit Facility resources are provided as outright disbursements without an arrangement.
Amendment of the Extended Financing Facility

In March 2012, the Executive Board approved an amendment to the Extended Fund Facility to allow extended arrangements to be approved for up to a maximum of four years from the outset. ${ }^{16}$ Previously, the policy allowed approval only for up to three years, with the possibility of subsequently extending the arrangement to a maximum of four years. Consistent with the spirit of the reforms of the IMF lending toolkit since 2009, which have injected substantial flexibility and allowed better tailoring to countries' varying circumstances and needs, the use of the EFF over time has broadened from low- and middle-income countries with prolonged balance of payments needs to more-developed countries facing larger financing needs, such as those that have arisen in the euro area crisis. Purchases under extended arrangements would be expected to be evenly phased, consistent with normal Fund practice. Implications of this change to the EFF for the design of blended EFF-PRGT financing, it was noted, would be considered in a subsequent review of facilities for low-income countries.

\section{Policy Support Instruments}

The Policy Support Instrument (PSI) supports low-income countries that do not wish-or need-to access Fund financial assistance but seek to consolidate their economic performance with IMF monitoring and support. This nonfinancial instrument is a valuable complement to the IMF's financing facilities under the PRGT. The PSI helps countries design and implement effective economic programs that, once approved by the Executive Board, deliver clear signals to donors, multilateral development banks, and markets regarding the Fund's endorsement of the strength of a member's policies.

Left Farmers view information about local government systems in Mwaro Province, Burundi. Right Villagers extract jute fiber near the India-Bangladesh border.
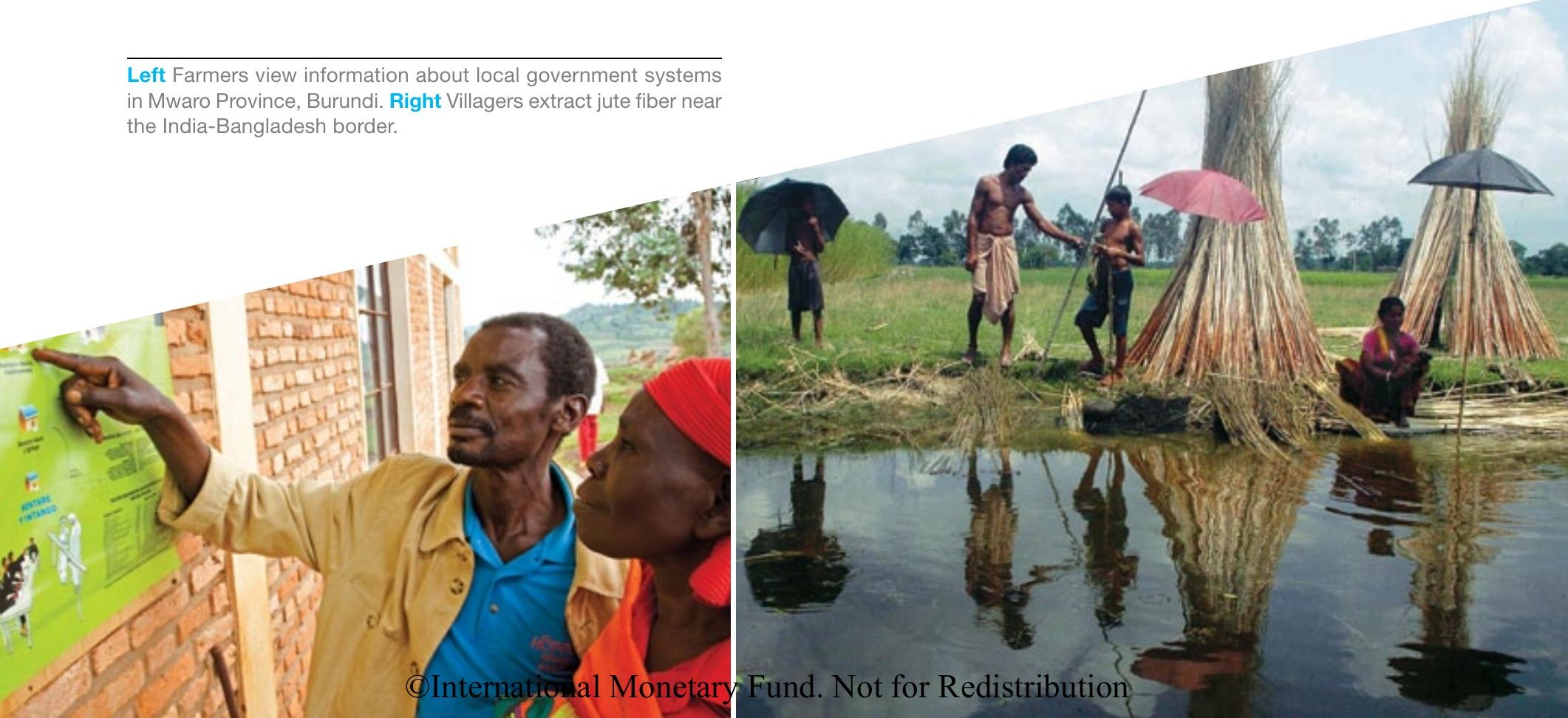
To date, the Board has approved PSIs for seven members: Cape Verde (2006 and 2010), Mozambique (2007 and 2010), Nigeria (2005), Rwanda (2010), Senegal (2007 and 2010), Tanzania (2007 and 2010), and Uganda (2006 and 2010). No new PSIs were approved in FY2012.

Macroeconomic and operational challenges in countries in fragile situations

Discussing macroeconomic and operational challenges in countries in fragile situations in July 2011, ${ }^{17}$ Executive Directors were heartened that, overall, IMF engagement with those countries had focused on the Fund's areas of expertise and helped strengthen macroeconomic frameworks, build up institutional and human capacity, and secure debt relief. However, Executive Directors noted that program implementation had been uneven, owing in part to overly ambitious program targets in some cases. Against this background, they saw merit in considering some changes to the modalities of the Fund's engagement, but stressed that - to be effective-efforts should remain focused on the Fund's core mandate and continue to be closely coordinated with the international community.

Most Executive Directors supported, or were open to considering, more flexible use of the Rapid Credit Facility for low-income countries in fragile situations as a stepping stone to upper-credittranche arrangements. ${ }^{18}$ Nevertheless, given the protracted balance of payments needs typically faced by countries in fragile situations, it was felt that upper-credit-tranche arrangements should remain the main vehicle of Fund engagement.

Executive Directors generally welcomed the call for greater flexibility in program design to better reflect the limited implementation capacity in states in fragile situations. At the same time, they underlined that the conditionality standards applicable to different financing facilities should be maintained. They agreed that IMF financing should taper out over the medium term, and that the long-term financing needs of countries in fragile situations should largely be met using concessional donor resources.

Executive Directors stressed the importance of technical assistance in lifting countries out of fragile situations. In this regard, they saw the need for grounding it in realistic and adequately supported medium-term plans, including reliance on resident advisors and continued training of country officials.

Systemic crises, financial linkages, and the role of global financial safety nets

In a June 2011 discussion on the analytics of systemic crises and the role of global financial safety nets, ${ }^{19}$ Executive Directors noted that the growing complexity of linkages among countries carries with it the risk of systemic instability, raising the odds of severe economic and financial distress and widespread contagion. They observed that the unprecedented policy response during the recent global crisis was commensurate with the scale of the crisis, which helped mitigate - and subsequently reverse - the loss of output and market confidence. More broadly, Executive Directors recognized that major central banks had played a crucial role in providing hard-currency liquidity during several systemic events, complementing efforts by the Fund and other international financial institutions. Although monetary policy decisions, in the context of the recent financial crisis, remained governed by central banks' domestic mandates and objectives, it was observed that these objectives happened to coincide with global interests. Going forward, it was noted, greater predictability and coordination of policy responses to systemic events would be desirable.

Most Executive Directors saw scope for exploring further enhancements to the global financial safety nets to provide timely and adequate liquidity to crisis bystanders, and, more generally, to foster greater global cooperation, particularly involving regional financing arrangements. Executive Directors underscored that strengthening the global financial safety net goes hand in hand with efforts to better identify the buildup of systemic risks and improve crisis prevention.

Subsequent to this discussion, in November 2011, the Board approved a set of reforms to the Fund's financing toolkit to better address liquidity and urgent balance of payment needs of the membership, as discussed earlier in the chapter.

\section{STRONGER SURVEILLANCE TO SUPPORT A RETURN TO SUSTAINABLE GLOBAL GROWTH}

\section{Strengthening surveillance}

The IMF is mandated, by its Articles of Agreement, to oversee the international monetary system and monitor the economic and financial policies of its 188 member countries, an activity known as "surveillance." As part of this process, which takes place both at the global level (multilateral surveillance) and in regard to individual countries (bilateral surveillance), the IMF highlights possible risks to stability and advises on needed policy adjustments. In this way, it helps the international monetary system serve its essential purpose of facilitating the exchange of goods, services, and capital among countries, thereby sustaining sound economic growth.

\section{Multilateral surveillance}

The IMF's key instruments of multilateral surveillance are three publications, the World Economic Outlook (WEO), the Global Financial Stability Report (GFSR), and the Fiscal Monitor (FM). These twice-yearly publications, along with the Regional Economic Outlook reports (see "Engagement with External Stakeholders" in 
Chapter 5), constitute the IMF's World Economic and Financial Surveys; they aid the Fund in its examination of economic and financial developments among the membership. Interim updates for the WEO, GFSR, and FM are issued twice a year.

The WEO provides detailed analysis of the state of the world economy and evaluates economic prospects and policy challenges at the global and regional levels. It also offers in-depth analysis of issues of pressing interest. The September 2011 issue of the WEO focused on rising risks with the slowdown in global economic growth. It included chapters on the appropriate monetary policy response to the inflationary effects of commodity price movements, and how changes in taxes and government spending affect an economy's external balance. The April 2012 issue examined the dangers remaining as growth resumed, with an analysis of how government policies can reduce the economic costs in the aftermath of housing busts, and a discussion of what policies commodity exporters should implement to handle price swings. The GFSR provides an up-to-date assessment of global financial markets and prospects and addresses emerging market financing issues in a global context. Its purpose is to highlight vulnerabilities that could pose risks to financial market stability. The main topic covered in the September 2011 issue was the legacies of the crisis; analytical chapters explored whether changes in investor behavior pose downside risks for global financial stability and offered guidelines for operationalizing macroprudential policies. The quest for lasting stability was the theme of the April 2012 GFSR, with an analysis of the role of safe assets as a cornerstone of financial stability and an assessment of the financial impact of longevity risk. The FM surveys and analyzes the latest public finance developments, updates reporting on fiscal implications of the global economic situation and medium-term fiscal projections, and assesses policies to put public finances on a sustainable footing. The September 2011 issue of the FM considered the topic of addressing fiscal challenges as a means of reducing economic risks, with analyses of fiscal devaluation, privatization episodes, debt monitoring, and stock-flow adjustments; the April 2012 edition examined ways of balancing fiscal policy risks, and included discussions of analytical work on fiscal multipliers, fiscal adjustment plans, and crisis impacts on subnational government finances. A survey of the issues covered in the WEO, GFSR, and FM in FY2012 is presented in Chapter 2.

As the global crisis underlined the need for more analysis of linkages between sectors (for example, real, financial, and fiscal) and countries, the IMF has taken a number of actions to help make its surveillance as interconnected as the global economy. Pilot "spillover reports" were prepared for the first time in 2011, assessing the impact of economic policies in the world's five largest systemic economies-China, the euro area, Japan, the United Kingdom, and the United States - on their partner economies. ${ }^{20}$ In September 2011, the IMF began preparing a new Consolidated Multilateral Surveillance Report, which highlights the top-line messages from the IMF's multilateral surveillance products (the WEO, GFSR, FM, and spillover reports); a second report was issued the following April. In 2012, the Executive Board held its first joint discussions on the WEO, GFSR, and FM, first in an informal session in January, and then in a formal Board meeting in April.

\section{Bilateral surveillance}

The centerpiece of the IMF's bilateral (or individual-country) surveillance is the Article IV consultation (see Web Box 3.2), normally held regularly with each member of the Fund in accordance with Article IV of the Fund's Articles of Agreement. In these consultations, the IMF conducts a thorough assessment of relevant economic and financial developments, prospects, and policies for each of its members, and provides candid policy advice based on its analysis. A total of 122 Article IV consultations were completed during FY2012 (see Web Table 3.1). In the vast majority of cases (for FY2012, 107, or 88 percent; see Web Table 3.1), the staff report and other analysis accompanying the consultation are also published on the IMF's website. The Executive Board reviews the implementation of the Fund's bilateral surveillance every three years, as part of its Triennial Surveillance Review.

\section{Triennial Surveillance Review}

In October 2011, the Executive Board concluded a comprehensive review of the IMF's surveillance activities - the Triennial Surveillance Review-and of the legal framework for surveillance. ${ }^{21}$ Executive Directors broadly agreed with the main conclusions of the IMF staff's review, in particular, that significant progress had been made in the way surveillance is conducted since the 2008 TSR, but that important gaps remained. They concurred with the staff that six areas of work deserve particular attention: interconnections, risk assessments, financial stability, external stability, the legal framework, and traction. They broadly endorsed the action plan described in the Managing Director's statement on strengthening surveillance, ${ }^{22}$ while noting differences of views on a number of points. They also endorsed the corresponding operational priorities for 2011-14 as proposed by the staff.

Interconnections. Executive Directors saw merit in strengthening the link between global and country-level analyses to inform policy recommendations at the bilateral level. They agreed that the analysis of outward spillovers, such as that employed in the spillover reports for five systemic economies (see "Multilateral Surveillance" earlier in the chapter), had been a useful contribution to Fund surveillance and should be repeated for those economies before taking stock in FY2013. Executive Directors strongly supported further use of cross-country analysis.

Risk assessments. Executive Directors agreed on the need to pay more attention, in bilateral and multilateral surveillance, to risks and their transmission channels, while not paying less attention to the baseline. In this regard, they generally supported the staffs proposals, including those in regard to better drawing on the results of existing risk assessment tools. 

Executive Directors shared the IMF staff's view that, for the Fund to better assess risks and understand cross-border financial linkages in an increasingly integrated global environment, more granular data are needed. Financial data on a residence basis, disaggregated by country, sector, instrument, maturity, and currency denomination, would facilitate, it was observed, the identification of interest rate and exchange rate risks, maturity mismatches or funding gaps, and the potential for spillovers. Executive Directors therefore encouraged the staff to continue to work to close the data gaps that had been identified.

Most Executive Directors also encouraged the staff to continue to work closely with the FSB Secretariat to finalize the data template for global systemically important financial institutions, develop statistical guidance, and establish an appropriate mechanism for data sharing among relevant official institutions. At the same time, Executive Directors emphasized that confidentiality rules and legal limitations on sharing firm-specific data in some jurisdictions would need to be addressed.

Executive Directors welcomed initiatives to improve the availability of data, including the Coordinated Portfolio Investment Survey and the Coordinated Direct Investment Survey. They encouraged the staff to further explore ways of reducing the reporting burden on member countries. They broadly supported efforts to expand the currency and country coverage of the Currency Composition of Foreign Exchange Reserves (COFER) database, while preserving current confidentiality arrangements. They welcomed the proposal to initiate bilateral consultations before implementing any changes. They also generally supported exploring the possibility of generating less-aggregated data for COFER, securities held in foreign exchange reserves, and instruments held in foreign exchange reserves, to facilitate better understanding of global capital flows and financial interconnections.

Executive Directors welcomed proposed enhancements of the Bank for International Settlements (BIS) International Banking Statistics, noting that this would help close important data gaps essential to the Fund's surveillance work.

The Executive Board also met informally in March 2012 to take up the topic of interconnectedness in the context of the Fund's work to enhance surveillance. In that informal discussion, Board members considered a staff paper that proposed a conceptual framework for better understanding the direct and indirect linkages of countries. Work on this important topic is ongoing.

Macroprudential policy development

Following an Executive Board discussion in April 2011 on an organizing framework for macroprudential policy, work proceeded in FY2012 on research for and development of the framework. The Board met informally to discuss two papers. The first analyzed institutional arrangements for macroprudential policy, set out criteria for assessing different models, and examined their strengths and weaknesses. The second analyzed country experiences with the use of macroprudential tools and assessed their effectiveness, concluding that most of the macroprudential instruments were effective in dampening procyclicality in the financial sector.

Anti-money laundering and combating the financing of terrorism

In their June 2011 discussion of an IMF staff paper on the effectiveness of the Fund's anti-money laundering and combating the financing of terrorism (AML/CFT) program, ${ }^{26}$ Executive Directors noted that the IMF's work had significantly contributed to the international community's response to money laundering and the financing of terrorism. (See Box 3.4 for highlights of AML/CFT efforts in two countries with IMF-supported programs.) They saw merit in exploring ways to strengthen AML/CFT assessments, including the possibility of conducting targeted, risk-based assessments. They agreed that, under a framework for risk-based assessments, the first AML/CFT assessment for a member would be comprehensive, while subsequent assessments would focus on those areas that presented the greatest risk of money laundering and/or terrorist financing taking place without being detected or sanctioned. They also agreed that a shift to targeted and risk-based AML/CFT Reports on the Observance of Standards and Codes ${ }^{27}$ would need to be agreed upon with the Financial Action Task Force (FATF) the standard setter-and other stakeholders. In particular, the methodology for conducting such assessments and criteria for the selection of issues to be assessed with respect to specific countries needed to be developed in cooperation with the FATF and the FATF-style regional bodies, along with other stakeholders. Most agreed to maintain the mandatory link of AML/CFT assessments with every assessment under the Financial Sector Assessment Program.

Executive Directors continued to support Fund collaboration with the FATF, including its International Cooperation Review Group process toward noncooperating jurisdictions. Consistent with guidance provided in the Board review of the Standards and Codes Initiative, ${ }^{28}$ Executive Directors agreed that the staff should continue to participate in the review group, play a "good offices" role, and provide relevant information on member countries under review with the consent of the relevant members, while refraining from participating in those aspects of the process that are coercive in nature. Executive Directors noted that staff participation in such cases should not be seen as an endorsement of possible public statements on noncooperating jurisdictions.

The majority of the Board endorsed the approach and considerations outlined in the paper for the coverage of AML/CFT issues and their related crimes in the context of modular financial stability assessments under the Financial Sector Assessment Program and bilateral surveillance. In addition, Executive Directors broadly supported the continued inclusion of AML/CFT issues in Article IV discussions on a voluntary basis. They noted that the next review of the AML/CFT program would be expected to be completed within the next five years. 
Box 3.4

Using anti-money laundering measures in Fund-supported programs: Afghanistan and Greece

Since stronger anti-money laundering controls can help prevent and mitigate the consequences of criminal behavior, ${ }^{\mathrm{a}}$ conditionality related to anti-money laundering (AML) measures is included in Fund-supported programs in Afghanistan and Greece.

In Afghanistan, the failure of Kabul Bank (the largest bank in the country as of July 2010) followed an alleged massive fraudulent and related-party lending scheme. If criminal behavior is proven, the loss, which amounts to more than US $\$ 900$ million (5 percent of GDP and more than 50 percent of government revenue for 2010), would represent one of the largest criminal bank losses relative to GDP in history. In the context of the IMF's Extended Credit Facility-supported program with Afghanistan, the authorities are, among other things, strengthening the country's legislation in the areas of banking and anti-money laundering and combating the financing of terrorism (AML/ CFT). Economic governance measures being taken include improving AML/CFT compliance, prioritizing fit and proper testing of persons who own and control financial institutions, and strengthening the supervisory framework and the independence of supervisors. Steps are also being taken to seek recovery of assets pilfered from Kabul Bank to minimize the fiscal cost of the crisis.

In October 2011, to strengthen their anti-tax evasion strategy, the Greek authorities decided to enhance the use of existing AML tools by implementing obligations on financial institutions to report, to the country's Financial Intelligence Unit, transactions suspected of being related to the proceeds of tax evasion. In March 2012, after the Financial Intelligence Unit had begun freezing assets allegedly related to the laundering of such proceeds, two AML measures designed to increase the flow of information from financial institutions and the tax administration to the Financial Intelligence Unit were introduced.

a More information on the Fund's work on AML/CFT issues can be found on the IMF's website at www.imf.org/external/np/leg/amlcft/eng/.

Work agenda for financial sector surveillance

As noted in the discussion of the 2011 Triennial Surveillance Review earlier in the chapter, one of the review's key recommendations was development of a strategic plan in regard to promoting financial stability. As a first step toward developing such a strategic plan, in April 2012, the Executive Board discussed a financial sector surveillance work agenda developed by the IMF staff. ${ }^{29}$

Executive Directors endorsed the key elements of the work agenda, which spans immediate priorities to contain the current crisis and medium-term priorities in two broad areas: enhancing systemic risk monitoring and distilling country experiences to derive best practices for resilient financial systems. They concurred with the staff that the immediate priority is to restore financial stability, notably but not only in the euro area, and limit spillovers to other regions. They stressed, however, that it is equally important for the IMF to continue engaging in all member countries and regions facing policy challenges, including emerging markets and low-income countries.

As regards medium-term priorities, Executive Directors stressed the need to understand better and monitor more effectively global systemic risk, build more resilient and growth-enhancing financial systems, and strengthen member countries' ability to prevent and manage crises. To that end, they supported efforts to refine the analysis of interconnectedness of financial sectors, understand better the linkages between the financial and real sectors, assess vulnerabilities in bank and nonbank institutions, and promote financial sector deepening. They also supported the Fund's efforts, alongside those of other stakeholders, to close data gaps and monitor risks arising from global systemically important institutions and markets.

Executive Directors agreed that it is important to engage other global stakeholders, including national authorities, on the development of a strategic plan. In doing so, it was noted, the Fund should focus on its mandate and areas of core competency, drawing on the expertise of other global stakeholders as needed. They urged that the plan contain specific actions, with clear priorities and timelines for implementation, and an assessment of the resource requirements.

\section{Fiscal policy}

\section{Modernizing the framework for fiscal policy and public debt} sustainability analysis

Noting that the recent global crisis had highlighted the need for increased focus on public debt sustainability in market access countries, especially advanced economies, in August 2011, the Executive Board discussed an IMF staff paper on modernizing the framework for fiscal policy and public debt sustainability analysis. ${ }^{30}$ Executive Directors generally supported the staff's proposals for giving greater consideration to several elements, such as the realism of baseline assumptions, the level of public debt as one of the triggers for further in-depth study, the analysis of fiscal risks, vulnerabilities associated with the debt profile, 
gaps, especially from the perspective of members and outside users, including gaps relating to the analysis of external stability. The Managing Director's April 2012 action plan calls for the IMF to bring multilateral consistency to its analysis of external stability with a new external sector report, which will examine what is driving imbalances and some of the associated risks to external stability. One important component of this report is expected to be external balance assessments, and an interdepartmental working group began developing the methodology for these assessments (the successor to the Consultative Group on Exchange Rates methodology), which will focus on current accounts, exchange rates, and net foreign assets. An informal Board meeting was held in March 2012 regarding the methodology and process for the external sector report, with a formal Board discussion expected in FY2013.

\section{Capital flows}

The Executive Board in FY2012 continued its earlier work toward formulating a comprehensive, flexible, and balanced approach for the management of capital flows, drawing on country experiences. Previous work focused on the policies of recipient countries and addressed the circumstances in which capital flow management measures would be appropriate.

\section{Multilateral aspects of policies affecting capital flows}

In November 2011 the Executive Board discussed an IMF staff paper on the multilateral aspects of policies affecting capital flows. ${ }^{32}$ Noting that policies of both source and recipient countries play a role in reaping the benefits of capital flows while limiting their risks, Executive Directors concurred with the staff that national policymakers should pay more attention to the multilateral transmission of their policies, including with respect to prudential frameworks and monetary policy. They agreed that improved national prudential frameworks benefit all countries and the global system as a whole. They noted that completing and fully implementing the national and international regulatory and supervisory reforms underway and developing new macroprudential frameworks would help reduce arbitrage opportunities and mitigate cross-border risks.

Most Executive Directors noted that, given the complicated transmission process, the case for major central banks to proactively consider the multilateral effects of their monetary policy is limited. Most agreed that the renewed interest in capital flow management measures suggested that their multilateral implications warrant attention, as capital flow management measures could transmit multilaterally by increasing or decreasing capital flows to countries with similar characteristics. Most also agreed that a moderate use of capital flow management measures has few implications for the overall riskiness of capital flows and global stability, noting, however, that such measures, if they proliferated or intensified, would have escalating global costs.

\section{Liberalizing capital flows and managing outflows}

In an April 2012 Executive Board meeting on liberalizing capital flows and managing outflows, Executive Directors concurred with IMF staff observations that full liberalization is not an appropriate goal for all countries at all times and that a country's appropriate degree of liberalization depends on its specific circumstances, notably the stage of its institutional and financial development. ${ }^{33}$ They noted that there is no single best approach to capital flow liberalization. They emphasized the need for a cautious approach to liberalization, paying attention to the institutional and market capacity to absorb capital flows and manage risks in an increasingly financially integrated world. Most Executive Directors considered 
the approaches proposed by staff for liberalizing capital flows and on the use of capital flow management measures to manage outflows as providing a broadly appropriate basis for developing a comprehensive institutional approach to inform policy discussions with member countries.

Most Executive Directors stressed that close attention should be paid to the multilateral effects of capital flow liberalization. It was observed that liberalization by large, systemically important emerging market economies could have significant multilateral effects, including through higher gross capital flows, a diversion of capital flows to or from other countries, implications for financial stability, and greater exchange rate flexibility. Many Executive Directors stressed that appropriate macroeconomic, structural, and financial sector policies should be the first line of defense against excessive, volatile capital outflows. A number of others saw a broader role for capital flow management measures as part of the permanent toolkit, which could be used effectively where macroeconomic or other policies are constrained.

Executive Directors acknowledged that the proposals discussed in the meeting would need to be reviewed periodically as the understanding of the underlying issues advanced. It was noted that a subsequent staff paper requested by the IMFC would articulate a comprehensive, balanced, and flexible approach for the management of capital flows, drawing on country experiences.

\section{Risk assessment and management}

The IMF has sharpened its risk assessments in the wake of the financial crisis. In 2009, the IMF introduced the Early Warning Exercise-to identify and assess low-probability but highimpact risks to the global economy-and has also developed analytic frameworks tailored to assessing vulnerabilities and emerging risks in advanced economies, emerging markets, and low-income countries. The exercise is typically conducted (in collaboration with the FSB) twice each year; following discussions at the Executive Board and with the FSB, the exercise's findings are presented to senior officials during the Spring and Annual Meetings. Closely connected to the Early Warning Exercise is the Early Warning List, a distillation of the key risks, vulnerabilities, and trends observed in work associated with that exercise that is shared with the IMF's Executive Board and members of the FSB.

The IMF's Vulnerability Exercises for Advanced Economies and Emerging Economies are a critical component of the broader research and analysis that feeds into the Early Warning Exercise's quantitative results. These Vulnerability Exercises use information from various models as an input to assess regional and global vulnerabilities to different types of shocks. Given their countryspecific nature, the results inform the Early Warning Exercise but are not circulated to the IMF's Executive Board or FSB members.

\section{Role of the SDR}

In October 2011, the Executive Board discussed criteria for broadening the SDR currency basket, a key element of the work program on SDR valuation and the reform of the international monetary system. ${ }^{34}$ Most Executive Directors were of the view that the existing criteria for SDR basket selection remained appropriate. Executive Directors stressed that the bar for SDR basket inclusion should not be lowered. They welcomed as a useful step indicators put forward by the IMF staff for the freely usable criterion ${ }^{35}$ in the context of the regular review of SDR basket valuation. They emphasized that the indicators should not be used mechanistically and that ultimately, the determination of free usability would need to rely importantly on judgment, framed by the definition of freely usable currency set out in the Articles of Agreement. A number of Executive Directors also stressed the importance of allowing changes in the basket to keep pace with developments in the international monetary system.

Most Executive Directors agreed that there continues to be an important role for a size-related criterion for SDR basket selection. While agreeing that augmenting the existing exports criterion with financial inflows would, in principle, be desirable, most Executive Directors preferred to maintain exports as the sole size criterion for the time being, pending further improvements in financial accounts data.

The Executive Board reviews the SDR basket, including candidate currencies for the basket and their weights, every five years. The next such review is expected to take place by 2015 . 


\section{BUILDING CAPACITY FOR SUSTAINED GROWTH}

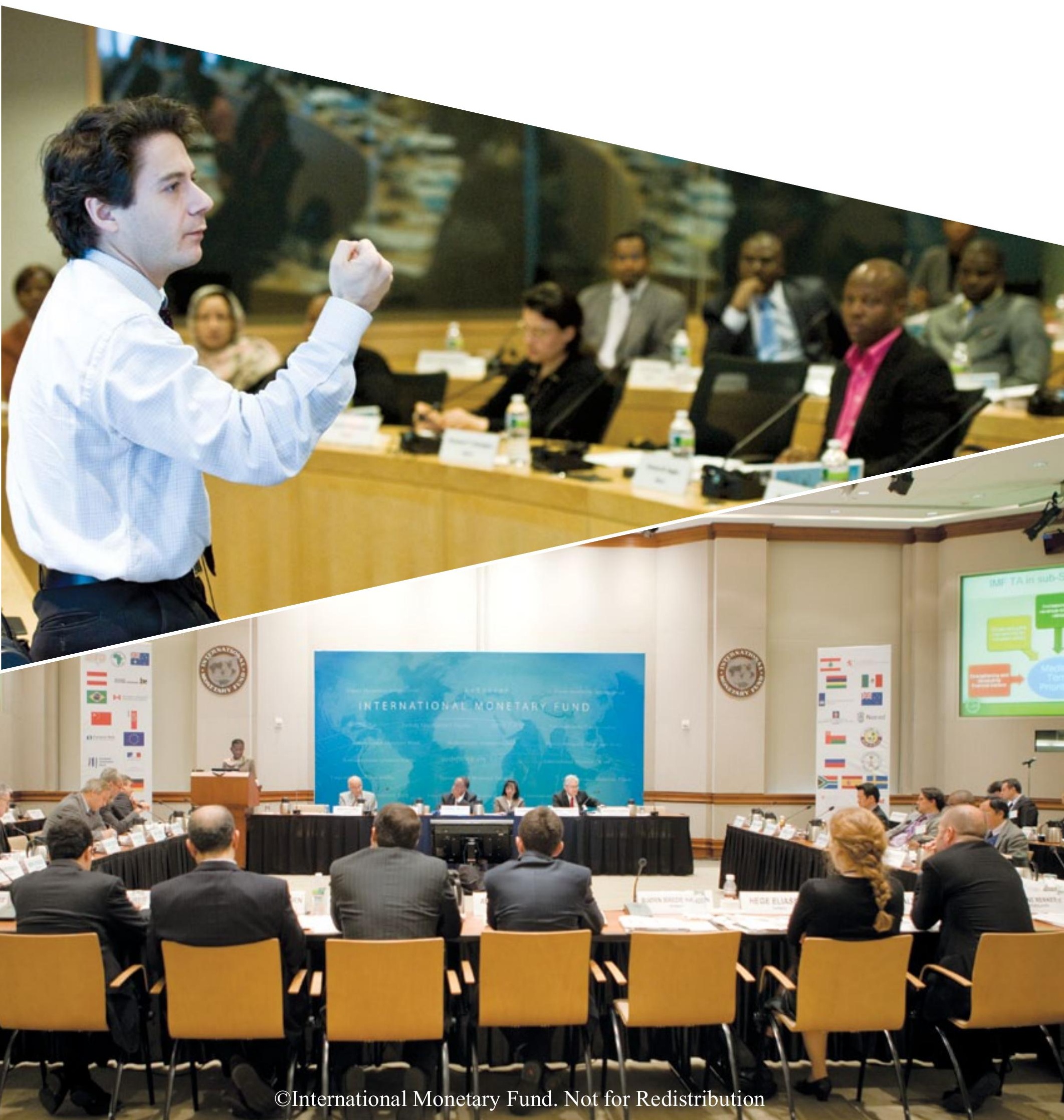




\section{BUILDING CAPACITY FOR SUSTAINED GROWTH}

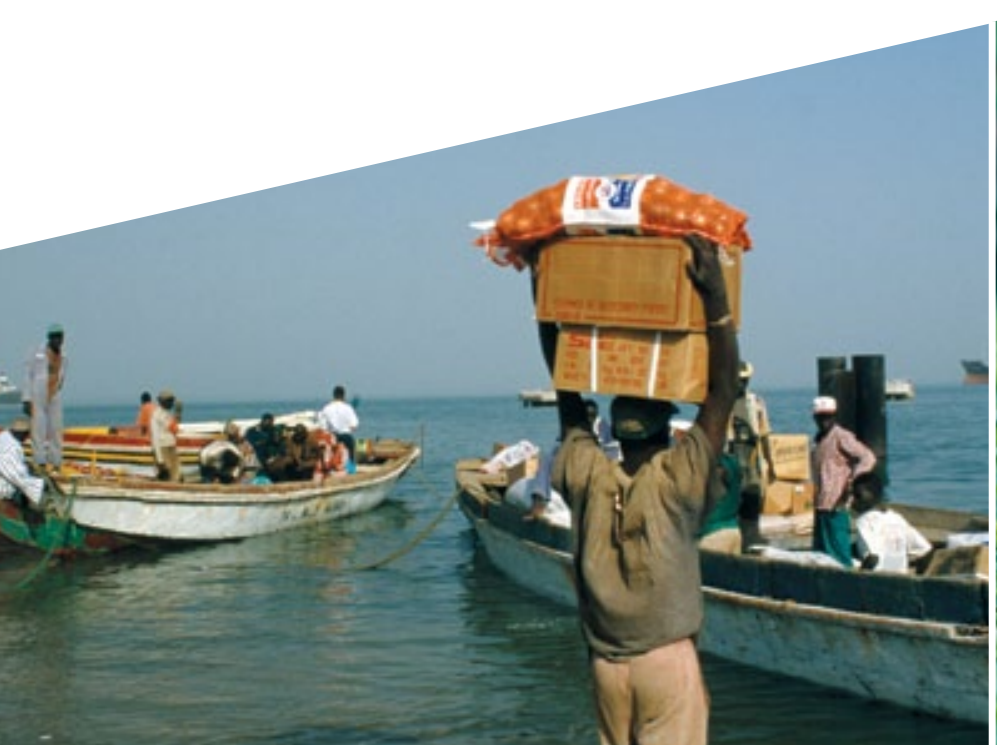

\section{SUPPORT FOR LOW-INCOME COUNTRIES}

Faced with lower fiscal buffers than before the onset of the crisis in 2008, and given uncertain prospects for donor assistance in the future, low-income countries remained highly exposed during FY2012 to global shocks. The IMF worked on several fronts to help low-income countries deal with these and other ongoing challenges they face. In addition to the concessional financing the Fund provided to low-income countries during the year, and the additional concessional resources it secured through use of windfall gold sale profits (see Chapter 3), as well as new borrowing agreements signed to support financing for low-income countries (see Chapter 5), the Executive Board took up a number of issues particularly pertinent to low-income countries during the year. Debt issues were addressed in Board reviews of the HIPC Initiative and MDRI, as well as of the IMF-World Bank debt sustainability framework for low-income countries. Additionally, the Board examined ways of managing global growth risks and commodity price shocks in these countries.

\section{Heavily Indebted Poor Countries and Multilateral Debt Relief Initiatives}

The joint IMF-World Bank comprehensive approach to debt reduction is designed to ensure that no poor country faces a debt burden it cannot manage. The two organizations launched the Heavily Indebted Poor Countries Initiative in 1996. Since then, the international financial community, including multilateral organizations and governments, has worked together to reduce to sustainable levels the external debt burdens of the most heavily indebted poor countries.

To be considered for HIPC Initiative assistance, a country must fulfill certain criteria, including that it must (1) be eligible for PRGT financing (see Chapter 3), (2) face an unsustainable debt burden that cannot be addressed through traditional debt relief mechanisms, (3) have established a track record of reform and sound policies through a Fund-supported program, and (4) have developed a poverty reduction strategy through a broad-based participatory process in the country. If a country satisfies all eligibility criteria and meets certain conditions, the Executive Boards of IMF and World Bank formally decide on its eligibility for debt relief, and the international community commits to reducing debt to a level that is considered sustainable. This first stage under the HIPC Initiative is referred to as the decision point. Once a country reaches its decision point, it may immediately begin receiving interim relief on its debt service falling due.

To receive the full and irrevocable reduction in debt available under the HIPC Initiative, a country must meet additional requirements, including that it must (1) maintain good performance under a Fund-supported program, (2) implement satisfactorily key reforms agreed to at the decision point, and (3) adopt a Poverty Reduction Strategy Paper and implement its 
poverty reduction strategy for at least one year. Once a country has met all these requirements, it can reach its completion point, which allows it to receive the full debt relief committed to at decision point.

As of April 30, 2012, of the 39 countries eligible or potentially eligible for HIPC Initiative assistance, 36 had reached their decision points; of these, 32 countries had reached their completion points. In total, through the Poverty Reduction and Growth-Heavily Indebted Poor Countries Trust, ${ }^{36}$ debt relief of SDR 2.5 billion has been provided under the HIPC Initiative for these 36 countries, 30 of which are in Africa.

In 2005, to help accelerate progress toward the UN Millennium Development Goals, the HIPC Initiative was supplemented with the Multilateral Debt Relief Initiative. The MDRI allows for 100 percent relief on eligible debts from three multilateral institutions - the IMF, the World Bank, and the African Development Fund - for countries eligible for PRGT assistance with annual per capita income below US $\$ 380$ and outstanding debt to the IMF at the end of 2004; in the case of counties that are eligible or potentially eligible for HIPC Initiative assistance, they must also have reached the HIPC completion point. In 2007, the Inter-American Development Bank also decided to provide additional debt relief to the five heavily indebted poor countries in the Western Hemisphere. All countries that reach the completion point under the HIPC Initiative, and those with per capita income below US\$380 and outstanding debt to the Fund at end-2004, are eligible for debt relief from the IMF under the MDRI. The Executive Board also requires that, to qualify for MDRI debt relief, these countries must be current on their obligations to the IMF and demonstrate satisfactory performance in macroeconomic policies, implementation of a poverty reduction strategy, and public expenditure management.

MDRI relief covers the full stock of debt owed to the IMF at end-2004 that remains outstanding at the time the country qualifies for such relief. There is no provision for relief of debt resulting from disbursements after January 1, 2005. In total, the IMF has provided debt relief of SDR 2.3 billion under the MDRI, including debt relief to two non-HIPCs. Although they have reached the completion point under the HIPC Initiative, Afghanistan, Haiti, and Togo had no MDRIeligible debt with the Fund and therefore did not receive debt relief from the IMF under this initiative. ${ }^{37}$

Proposals for the future of the HIPC Initiative and MDRI

In November 2011, the Executive Board discussed the status of implementation of the HIPC Initiative and the MDRI, as well as proposals for their future. ${ }^{38}$ Executive Directors considered that the objectives of the initiatives had been largely achieved. It was observed that most HIPCs had qualified for debt relief and reached the completion point. Nevertheless, it was also observed that many HIPCs continued to face other challenges in meeting the Millennium Development Goals, and several were still at high risk of debt distress.

Executive Directors noted that some issues required continued attention in order to implement the initiatives fully. Sustained efforts were needed to bring the remaining seven countries, ${ }^{39}$ particularly those that had not yet reached the decision point, to the completion point. Full participation of all creditors - particularly a number of smaller multilateral, non-Paris Club bilateral, and private creditors-had yet to be secured. Limiting the incidence and impact of commercial creditor litigation against HIPCs remained important. Finally, additional funds would need to be mobilized to ensure that there were adequate resources for debt relief to all remaining HIPCs, including those having protracted arrears to international financial institutions.

Executive Directors supported a proposal to streamline reporting of progress under the HIPC Initiative and MDRI. Most agreed that the annual status-of-implementation report should be discontinued. Executive Directors agreed that the core information-on debt service and poverty-reducing expenditure, the cost of debt relief, creditor participation rates, and litigation against HIPCs - should continue to be made available and updated regularly on the IMF and World Bank websites.

Executive Directors welcomed a proposal to enhance the monitoring of, and reporting on, the debt situation in all low-income countries, including HIPCs, through a periodic report, drawing on annual debt sustainability analyses and other pertinent information. They considered this important, in view of the significant share of low-income countries with elevated debt distress ratings and the increasing use of nonconcessional borrowing in a number of them. In this context, Executive Directors stressed the need for continued concessional financing to support countries' development agendas.

Executive Directors agreed to add an end-2010 indebtedness criterion for eligibility for assistance under the HIPC Initiative, as well as to ring-fence further the list of eligible or potentially eligible countries based on that criterion. In supporting this proposal, most Executive Directors considered that this limited change would reduce moral hazard and bring a further sense of closure to the HIPC Initiative. Executive Directors generally agreed with a proposal not to include remittances in considering the repayment capacity of HIPCs. They noted that such a change could possibly disqualify from assistance countries that would be eligible under current rules, or lower the amount of assistance to future HIPCs relative to what previous post-completion-point HIPCs had received. 


\section{Review of the Joint IMF-World Bank Debt Sustainability Framework for Low-Income Countries}

In a February 2012 review of the joint IMF-World Bank debt sustainability framework for low-income countries, ${ }^{40}$ Executive Directors noted that experience with the framework to date had suggested that it had performed relatively well and fulfilled its main objectives. They agreed nevertheless that some modest improvements were necessary in light of changing circumstances in low-income countries, to ensure that the framework remained robust and relevant.

Most Executive Directors agreed that the indicative policydependent thresholds used in the framework remained broadly valid. Executive Directors emphasized the need to exercise judgment when considering cases in which remittances should be included and when interpreting breaches of external debt thresholds more broadly. They endorsed a proposal to maintain all other thresholds at their then-current values and recommended that revisions to the framework be explained to country authorities and communicated carefully to the public.

Noting the growing role of domestic debt in some low-income countries, Executive Directors generally saw scope for strengthening the analysis of total public debt and fiscal vulnerabilities, including those from contingent liabilities. Most Executive Directors supported proposed benchmarks for total public debt to help determine when to conduct deeper analysis, including in the discussions with country authorities, while cautioning that such benchmarks should not be used mechanically. Executive Directors agreed that country-specific information should be taken into account more systematically when assessing the risk of debt distress and broadly supported more consistent use of judgment in this regard. They welcomed a plan to develop clearer guidance for staff and supported analytical work on alternative approaches to complement the current methodology.

Executive Directors generally welcomed efforts to simplify the debt sustainability analysis template, which would allow country authorities to produce their own debt sustainability analyses more easily, gradually building up their capacity and enhancing the policy dialogue on debt issues. They also supported a proposal to produce full joint debt sustainability analyses every three years, with lighter updates in the interim years, while maintaining the flexibility to prepare full analyses if warranted by circumstances, including those prompting a request for use of Fund resources.

\section{BUILDING CAPACITY IN MEMBER COUNTRIES}

Capacity building, consisting of technical assistance and training, is one of the Fund's three core activities, integrated with the other two, surveillance and financing. It supports the Fund's strategic priorities, reinforcing member capacities in the fiscal, legal, monetary and financial markets, and statistics areas.

Following an Executive Board discussion in November 2011 of a report by the Task Force on the Fund's Technical Assistance Strategy, the IMF announced in early 2012 that it planned to merge two existing Fund organizational units, the IMF Institute and Office of Technical Assistance Management, to create a new department focused on helping member states build capacity and develop their key economic and financial institutions. The new Institute for Capacity Development, which became operational at the beginning of FY2013, will help to further refine and update the Fund's capacity-building strategy, combined with periodic reviews for the Board; enhance partnerships with donors and other key stakeholders; explore and use synergies between regional training centers and regional technical assistance centers; design and deliver training that reflects member countries' and the Fund staff's needs; expand the use of innovate training methods; and engage in more effective outreach.

\section{Technical assistance}

Demand for IMF technical assistance was again heavy in FY2012, and thanks to donor contributions, the IMF was able to deliver about 17 percent more TA in the field than in FY2011, serving most of its member countries. More than 60 percent of the year's TA was delivered to low- and lower-middle-income countries (see Figure 4.1), but the effects of the global financial crisis also increased demand among upper-middle-income countries. Countries with IMF-supported programs also saw increased TA needs (see Figure 4.2), and TA to fragile states rose substantially, accounting for almost 20 percent of total IMF TA.

Although TA delivery increased across all areas, demand for TA on fiscal issues was particularly high, with more than half of FY2012 technical assistance being delivered in this area (see Figures 4.3 and 4.4). Among regions, Africa continued to be the largest recipient of IMF TA, accounting for almost 40 percent.

\section{TA advice}

In FY2012, TA in the fiscal area responded to new crisis-related demands while continuing to support reforms initiated earlier to help crisis countries implement their adjustment programs. Fund TA also supported the transformation of fiscal regimes and institutions, in particular in response to continuing economic problems in Europe and geopolitical developments in the Middle East, even as demand for TA on traditional fiscal issues held steady.

For fiscal TA in traditional areas, the demand for advice on tax policy was particularly heavy, notably for natural resource fiscal regimes and tax gap analysis. A revenue administration fiscal information tool was introduced, as one element in a revenue 


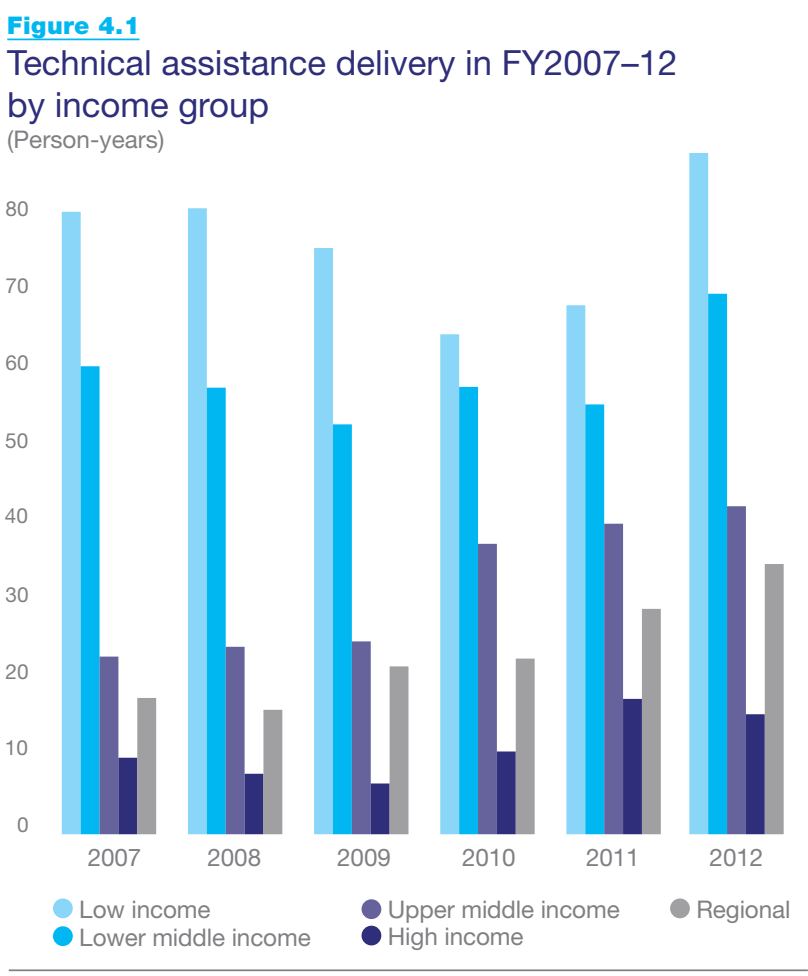

Source: IMF Institute for Capacity Development.

administration diagnostic toolkit being developed by the Fund. The tool is designed to support revenue administration benchmarking for 100 countries, mainly those of low and lower-middle income. Another toolkit element, gap analysis, was used during the year for value-added tax gap analysis in member countries. Demand was also high for assistance in rationalizing government expenditures, reinforcing pension systems, setting up medium-term fiscal frameworks to tighten budget execution and expenditure controls and improve cash and debt management, and strengthening tax and customs administrations.

In the areas of monetary and financial policy, the crisis also continued to spur new TA demands, including from advanced economies. Significant TA interventions focused on the development of regulatory reform, deposit insurance schemes, macroprudential policy frameworks, systemic liquidity management, crisis resolution and exit strategies, and managing public sector balance sheet risks.

The core traditional area of TA on monetary and financial sectors was in advising central banks on monetary operations and policy and developing financial supervision and regulation. In particular, strengthening banking supervisory capacity and frameworks underpinned the TA objectives for two multiyear regional projects as well as more than 20 individual country projects. Substantial TA was also provided toward improving financial stability frameworks, particularly in Africa.
Figure 4.2

Technical assistance delivery in FY2007-12

by country status

(Person-years)

200

150

100

50 2007

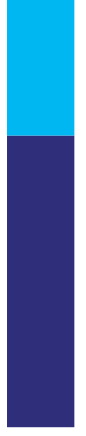

2008

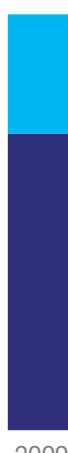

2009

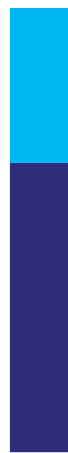

2010

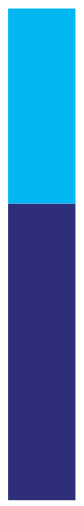

2011

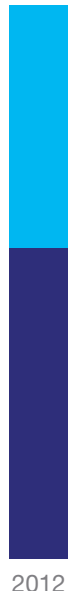

2012
Source: IMF Institute for Capacity Development.

Note: Data do not include training delivered by the IMF Institute.

\section{Figure 4.3}

Technical assistance delivery during FY2012 by subject and region

(Person-years)

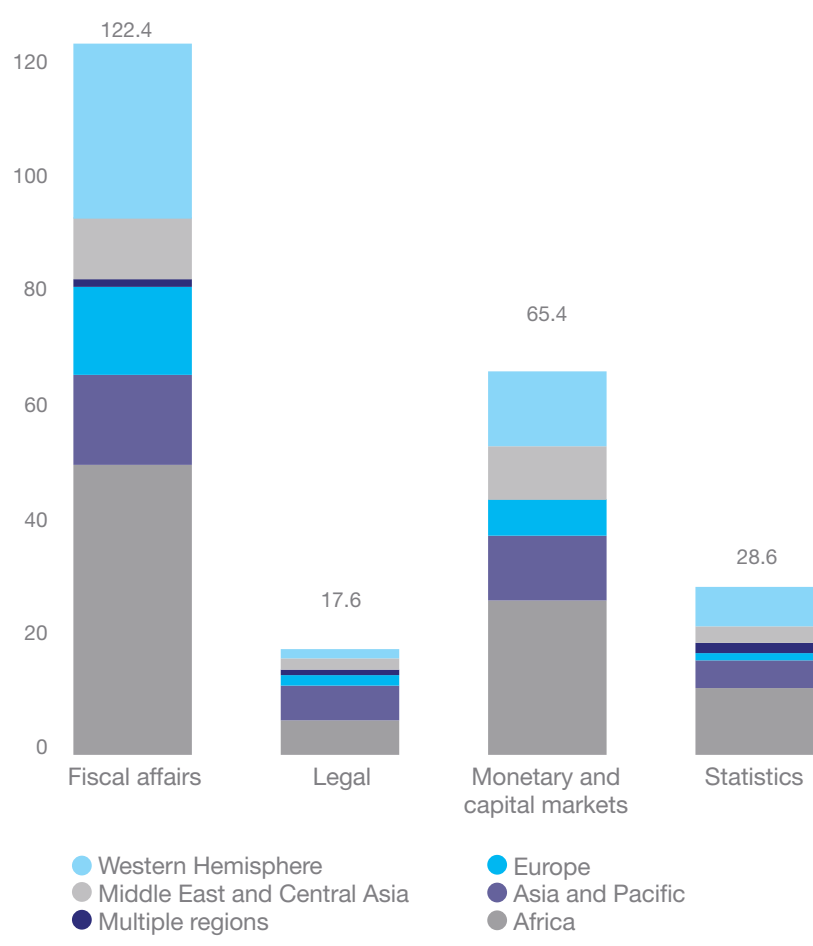

Source: IMF Institute for Capacity Development. 
Figure 4.4

Technical assistance delivery in FY2007-12 by subject and topic

(Person-years)
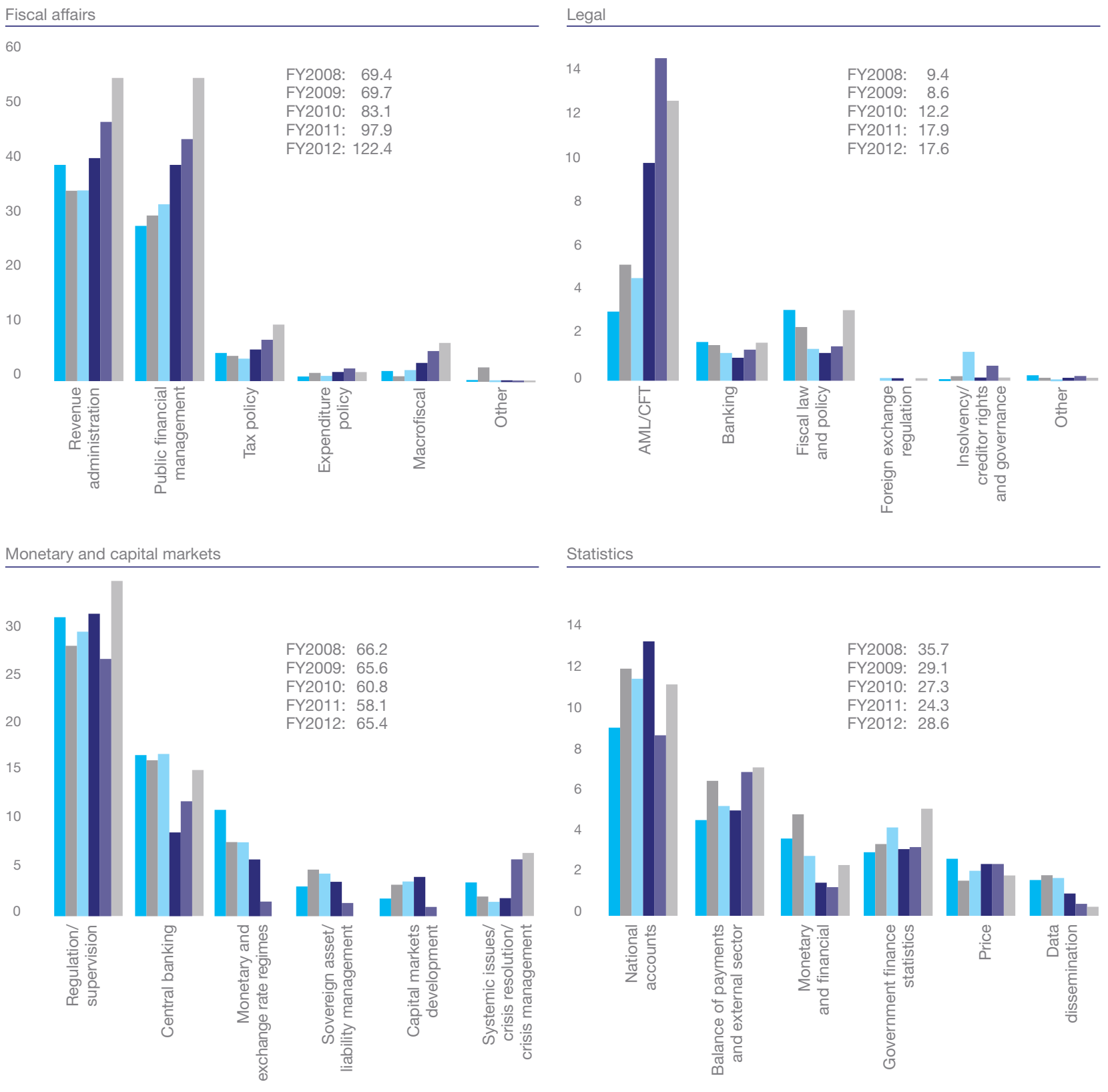
TA on legal issues focused in the areas of anti-money laundering/combating the financing of terrorism, financial sector and banking, and taxation. Demand for AML/CFT technical assistance, delivered primarily through the corresponding topical trust fund, exceeded staff resources for the fourth straight year. Financial sector TA focused on central banking legislation, bank regulation and supervision, payment systems, derivatives market regulation, and foreign exchange. Fiscal sector TA focused on budget law issues and a broad range of tax and tax procedure issues in several countries.

Work continued in FY2012 to help countries improve the compilation and dissemination of macroeconomic and financial statistics. Three new projects sponsored by the Japan Administered Account for Selected IMF Activities were launched in FY2012, for improving the compilation of real sector statistics in nine Eastern European countries, improving the compilation of government finance statistics in Asia and the Pacific, and helping interested countries improve data dissemination practices and participate in the IMF's General Data Dissemination System. Progress continued on a project sponsored by the United Kingdom's Department for International Development that aims at promoting better economic data in Africa, with three African countries releasing quarterly GDP data to the public for the first time at the end of 2011. TA under this project was also instrumental in Mauritius's subscription to the IMF's Special Data Dissemination Standard (see "The IMF's Standards for Data Dissemination" later in the chapter). Meanwhile, two new courses at the Singapore Training Institute were introduced in the area of statistics to develop member countries' capacity for understanding financial linkages.

\section{Fundraising in support of IMF TA}

Donor contributions have allowed the IMF to respond effectively to rising demand for TA during a period when its own resources have been constrained (see Figure 4.5). In FY2012, externally financed TA exceeded US\$107 million (US\$74 million in FY2011), accounting for some 40 percent of the IMF's budget for capacity development and more than 70 percent of field delivery. The number of donors, including recipient countries contributing to regional technical assistance centers, increased from 50 in FY2008 to more than 75 in FY2012. The largest donors for TA activities, with commitments of about US\$30 million or more over a five-year period, are Japan, the United Kingdom, Canada, the European Union, Switzerland, and Australia.
Bilateral partnerships

In bilateral partnerships, donors finance country-specific or multicountry projects. Japan is the largest donor to IMF TA (see Box 4.1), contributing close to 46 percent of external financing over FY1990-2012. In FY2012 cooperation with the European Union via bilateral agreements intensified, as did the strategic partnership more generally. Meanwhile, the IMF continues to cooperate closely with other long-time supporters, such as Norway, the Netherlands, France, Belgium, and New Zealand, which have continued to support IMF TA during difficult times despite fiscal pressures. The IMF is also working to deepen relations with donors like Korea and build partnerships with new donors like China.

Leveraging donor resources

In recent years two major initiatives - regional technical assistance centers (RTACs) and topical trust funds (TTFs) — have made it possible for the IMF to pool resources from multiple donors to bring its expertise closer to users, through the RTACs, and to zero in on specialized areas, through the TTFs.

RTACs allow the IMF to tailor TA to meet a region's unique needs, coordinate more closely with other assistance providers, and respond faster as new needs emerge. There are now eight RTACs, half in Africa and the remainder in the Caribbean, Central America, the Pacific, and the Middle East.

\section{Figure 4.5}

Technical assistance delivery in FY2008-12 by financing source (Person-years)

200

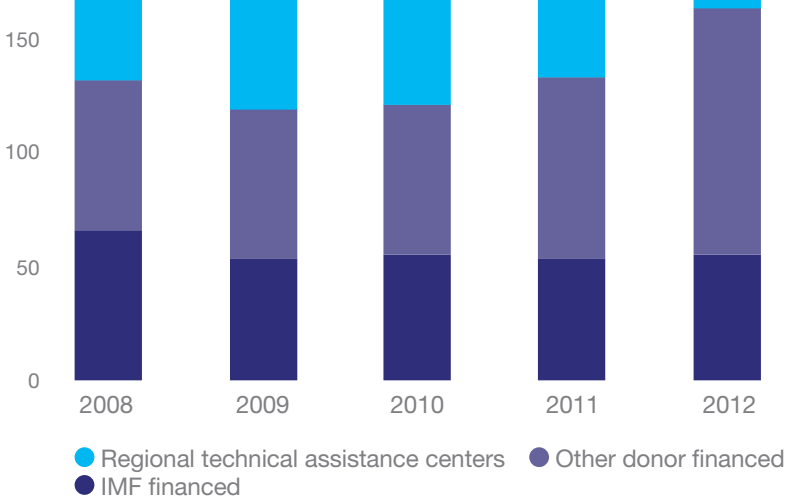

Source: IMF Institute for Capacity Development. Note: Data do not include training delivered by the IMF Institute. 


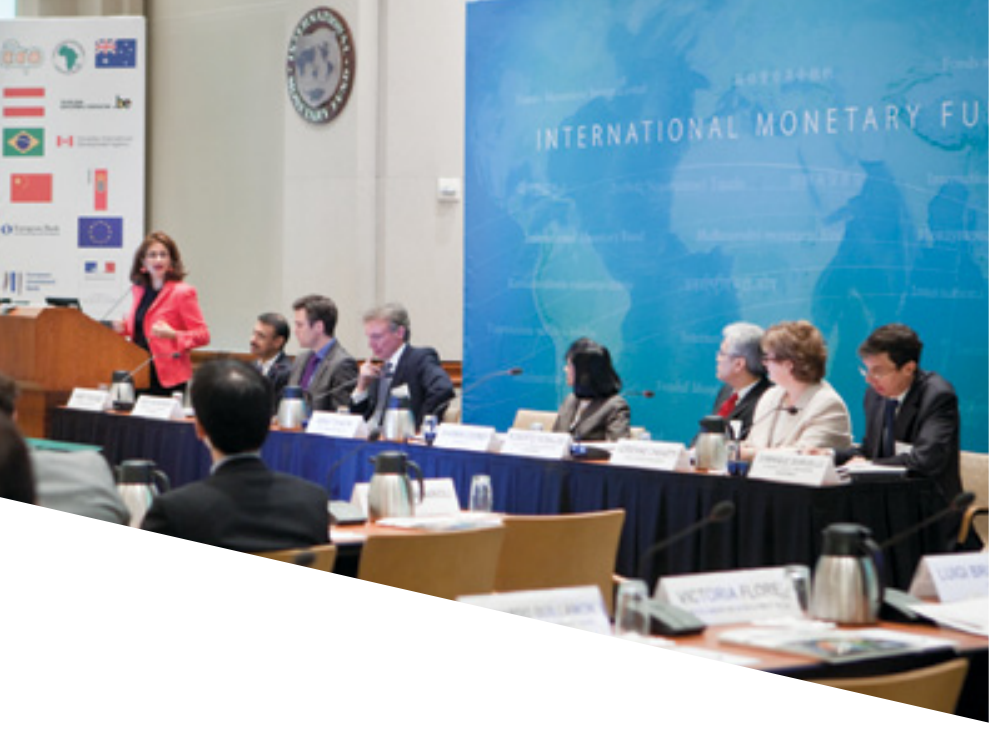

Left Deputy Managing Director Nemat Shafik addresses the Donor Consultative Group meeting at the 2012 Spring Meetings in Washington, D.C. Right Deputy Managing Director Min Zhu (left) and African Department Director Antoinette Sayeh (center left) join Bank of Mauritius Governor Rundheersing Bheenick (center right) and Vice Prime Minister and Minister of Finance and Economic Development Xavier-Luc Duval (right, cutting ribbon) to inaugurate AFRITAC South at the Bank of Mauritius.

With very strong donor support, the RTACs have achieved a great deal in the regions they serve. The East Africa Regional Technical Assistance Center (East AFRITAC), the first RTAC in Africa, celebrated its tenth anniversary in FY2012. The IMF was also able to expand its network of RTACs in FY2012. AFRITAC South opened in Mauritius in June 2011, serving countries in southern Africa, with early support from the African Development Bank, Australia, Brazil, Canada, the United Kingdom, the European Investment Bank, the European Union, Mauritius as host country, and some recipient countries. Another RTAC (AFRITAC West 2) is expected to open in West Africa in 2013 to serve nonfrancophone countries in the region; this will complete RTAC coverage of sub-Saharan Africa. Funding drives are underway to support the continuing activities of the current RTACs in response to increasing TA demand.

Box 4.1

\section{Japan's contribution to IMF technical assistance}

Since 1990, Japan has consistently been the IMF's leading partner in the financing of the IMF's technical assistance (TA) program and the largest single contributor to IMF TA and training activities. Contributions by Japan in FY1990-FY2012 amounted to about US\$433.5 million, with US\$30.8 million in FY2012 alone, including US\$22.9 million for TA projects and programs, US\$2.7 million for activities of the Regional Office for Asia and the Pacific, and US\$5.2 million for two scholarship programs. The Japan Subaccount under the Framework Administered Account for Selected Fund Activities is the current vehicle for Japan's contributions.
The three existing TTFs complement the RTACs, bringing specialized IMF expertise to bear to help members combat money laundering and the financing of terrorism, improve tax policy and administration, and manage natural resource wealth. The first TTF, on AML/CFT, began operations in May 2009 and is delivering assistance to improve members' AML/CFT regimes. The IMF's Legal Department provides most AML/CFT technical assistance, and the lead donors for the trust fund are Switzerland, Norway, Canada, and the United Kingdom. A recent external evaluation concluded that the management of the AML/ CFT topical trust fund has achieved a great deal in a short time with results that are far better than could be expected only two and a half years into the program. Recommendations included suggestions on project and program design and management and monitoring, including information management systems and results-based management.

Recognizing that capacity building takes time, in FY2010, Japan decided to replace the conventional project approach with a programmatic approach. As a result, programs funded through the Japan Subaccount now typically span three years and usually cover multiple countries and TA topics. Eighteen ongoing programs were being funded by the end of FY2012with a combined budget of US\$55.3 million-with the expectation of more substantial and lasting results for recipients. 
The second and third TTF deliver TA on tax policy administration and managing natural resources wealth. The former, which began operations in May 2011, works mainly with low- and lower-middle-income countries to mobilize domestic resources to support development and reduce aid dependency. The latter, which also started in May 2011, targets 51 countries that have substantial current or prospective hydrocarbon and mineral resources. Many donors support both TTFs; major donors are Australia, Belgium, the European Union, Germany, Kuwait, Luxembourg, the Netherlands, Norway, Oman, and Switzerland.

The IMF also is conducting fundraising for three additional trust funds that are planned: those for South Sudan, sustainable debt strategy, and training for Africa.

Donor Consultative Group meeting

Responding to strong donor interest in enhanced coordination and strategic consultation, the IMF hosted the first Donor Consultative Group meeting during the 2012 Spring Meetings. Participants included nearly 50 representatives from almost 30 current and potential donor agencies and other development partners. The meeting centered on the IMF's capacity development strategy, regional priorities in Africa and the Middle East, performance measurement, the IMF's planned trust fund for debt strategies, and fundraising activities. Donor representatives welcomed the IMF's recent progress toward introducing a results-based management framework for planning and monitoring the effectiveness of capacity-building initiatives. Participants agreed that it would be advisable for donors and the IMF to meet at least every other year, and possibly annually, to discuss strategic issues.

Donor survey

The IMF staff conducted a donor survey in September 2011. Donors were found to view IMF TA as generally effective and of high quality, and a majority rated IMF TA experts to be of higher quality than those of other providers. However, they also identified scope to improve TA follow-up, better coordinate with other providers, become more results oriented, and raise the visibility of donors.

Improving TA effectiveness and increasing its visibility

Review of the Fund's TA strategy

In November 2011, the Executive Board reviewed the Fund's TA strategy. An IMF staff paper was presented that recommended a FINE model: TA must be focused on the Fund's core macro mandate, integrated with IMF surveillance and program responsibilities, nimble, as the global crisis clearly demonstrated the importance of quick response, and effective in providing outcome-focused, cutting-edge advice to meet members' evolving needs. A number of areas in which significant change is needed were also identified-such as more flexible human resources policies, greater outreach on TA to members and the public at large, and exploitation of synergies between TA and training.

\section{TA seminar}

To increase visibility for the Fund's TA work, the first interdepartmental seminar on IMF TA was held during the September 2011 Annual Meetings. To illustrate how IMF TA and training can help tackle crises and build institutions for the future, IMF staff members presented examples of their work on capacity building, and high-level speakers and panelists from recipient countries recounted their experiences with IMF TA.

\section{Training}

Training for member country officials is an integral part of the IMF's capacity-building efforts. Courses and seminars are designed to share the expertise of the IMF staff on a wide array of topics that are critical to effective macroeconomic and financial analysis and policymaking, including courses on the compilation of macroeconomic statistics and various fiscal, monetary, and legal issues. Most of the training is provided through a program organized by the IMF Institute (in collaboration with other departments), ${ }^{41}$ delivered mainly at IMF headquarters, at seven regional training centers around the world, and through distance learning.

A key medium-term goal has been to rebuild the volume of training with donor support, following cuts in FY2009 owing to the IMF's restructuring exercise. This was achieved in FY2012, with the support of external donors and training partners. A record amount of training-almost 10,000 participant-weeks - was delivered through the IMF Institute program (see Table 4.1), and 4,750 officials attended the training (a 13 percent increase from the previous year). Training for Arab League countries received a substantial boost with the launch of the new IMF-Middle East Center for Economics and Finance in Kuwait in May 2011. The IMF Institute further strengthened the evaluation of training, providing additional feedback to donors (see Box 4.2).

The training curriculum is continually adapted to the IMF's priorities and the evolving needs of member countries; to this end, additional training was provided in FY2012 on topics such as macroeconomic diagnostics and financial sector issues. 
Box 4.2

Evaluating the effectiveness of IMF Institute training

The IMF Institute (now part of the Institute for Capacity Development) utilizes a variety of monitoring and evaluation techniques to ensure that its programs are meeting the training needs of member countries. These include (1) quantitative and qualitative evaluations of training from the participants at the end of every course, (2) input from the Institute's partners at the regional training centers, (3) brainstorming meetings with senior country officials, (4) triennial surveys of participants' sponsoring agencies, and (5) follow-up surveys one year to eighteen months after a sample of courses, to assess whether benefits from the training are sustained. Surveys are conducted by an internationally known, independent market research firm to ensure anonymity of the responses. In FY2012, the Institute launched its first tracer study to determine the longer-term impact of training courses on participants' work, careers, and agencies. The feedback obtained through all these evaluation channels during FY2012 was very positive.

The latest triennial survey was conducted in early 2012 by Harris Interactive. Harris reported that 98 percent of responding agencies expressed satisfaction with Institute training-the highest approval ever-with 77 percent of respondents expressing "strong" satisfaction (Harris considers "strong satisfaction" of more than 67 percent to be particularly significant). Moreover, 92 percent of respondents said that their staff values IMF training more than training by other providers on similar topics. The majority of agencies surveyed expected their need for IMF

\section{DATA AND DATA STANDARDS INITIATIVES}

\section{The IMF's standards for data dissemination}

Data dissemination standards help enhance the availability of timely and comprehensive statistics, which contributes to the pursuit of sound macroeconomic policies. Among the steps the IMF has taken to enhance transparency and openness is the establishment and strengthening of data dissemination standards to guide countries. The Special Data Dissemination Standard (SDDS), established in March 1996, is intended to guide members in the provision of their economic and financial data to the public. The General Data Dissemination System (GDDS), established the following year, provides a framework to help countries develop their statistical systems to produce comprehensive and accurate statistics for policymaking and analysis. Participation in the SDDS and GDDS is voluntary; many countries use participation in the GDDS as a step toward subscription to the SDDS. ${ }^{42}$

The former Yugoslav Republic of Macedonia, Mauritius, and West Bank and Gaza subscribed to the SDDS during FY2012, bringing the number of subscribing economies to $71 .{ }^{43}$ Burundi, Djibouti, training courses to increase further over the subsequent five years (2012-16). The survey also indicated robust demand across topic areas.

Follow-up surveys were conducted during the year to assess whether benefits from training are being sustained. Questionnaires were sent to training participants, and to the managers in their agencies who had sponsored their participation in the training. The surveys included several questions about how IMF training contributes to building capacity in member countries. Participants and their sponsors in the eight follow-up surveys overwhelmingly confirmed that the training has helped participants do their jobs better (98 percent) and improved the way they formulate and implement policy (95 percent). In addition, respondents confirmed that the knowledge gained has been shared with colleagues (96 percent), and that participants' career opportunities have increased as a result of their Institute training ( 90 percent). The most positive feedback on most questions came from participants' managers.

The inaugural tracer study was conducted among officials who had attended more than one course at the Joint India-IMF Training Program. The response rate was impressive, and officials confirmed overwhelmingly that their job performance has improved as a result of the training they received and that they have shared what they learned with colleagues. Many participants provided specific examples of how the training has contributed directly to their job or institution.

Guyana, Maldives, Montenegro, Papua New Guinea, and the Solomon Islands all joined the GDDS between June 2011 and February 2012,44 bringing to 103 the number of GDDS participants (excluding the economies that have graduated from the GDDS to the SDDS). Comprehensive information on the statistical production and dissemination practices of all of these countries appears on the IMF's Dissemination Standards Bulletin Board, which provides access to the SDDS, GDDS, and Data Quality Reference sites. ${ }^{45}$

As part of the Eighth Review of the IMF's Data Standards Initiatives (see next section), the Executive Board approved creation of the "SDDS Plus," which is open to all SDDS subscribers but is aimed at economies with systemically important financial sectors. The SDDS Plus includes standards for nine additional data categories that an interested country commits to fully observe by the end of 2019. These data categories refer to the four macroeconomic sectors: real (sectoral balance sheets), fiscal (general government operations and general government gross debt), financial (other financial corporations survey, financial soundness indicators, and debt securities), and external (Coordinated Portfolio Investment Survey, Coordinated Direct Investment Survey, and COFER). Adhering to the SDDS Plus is voluntary, but once a 


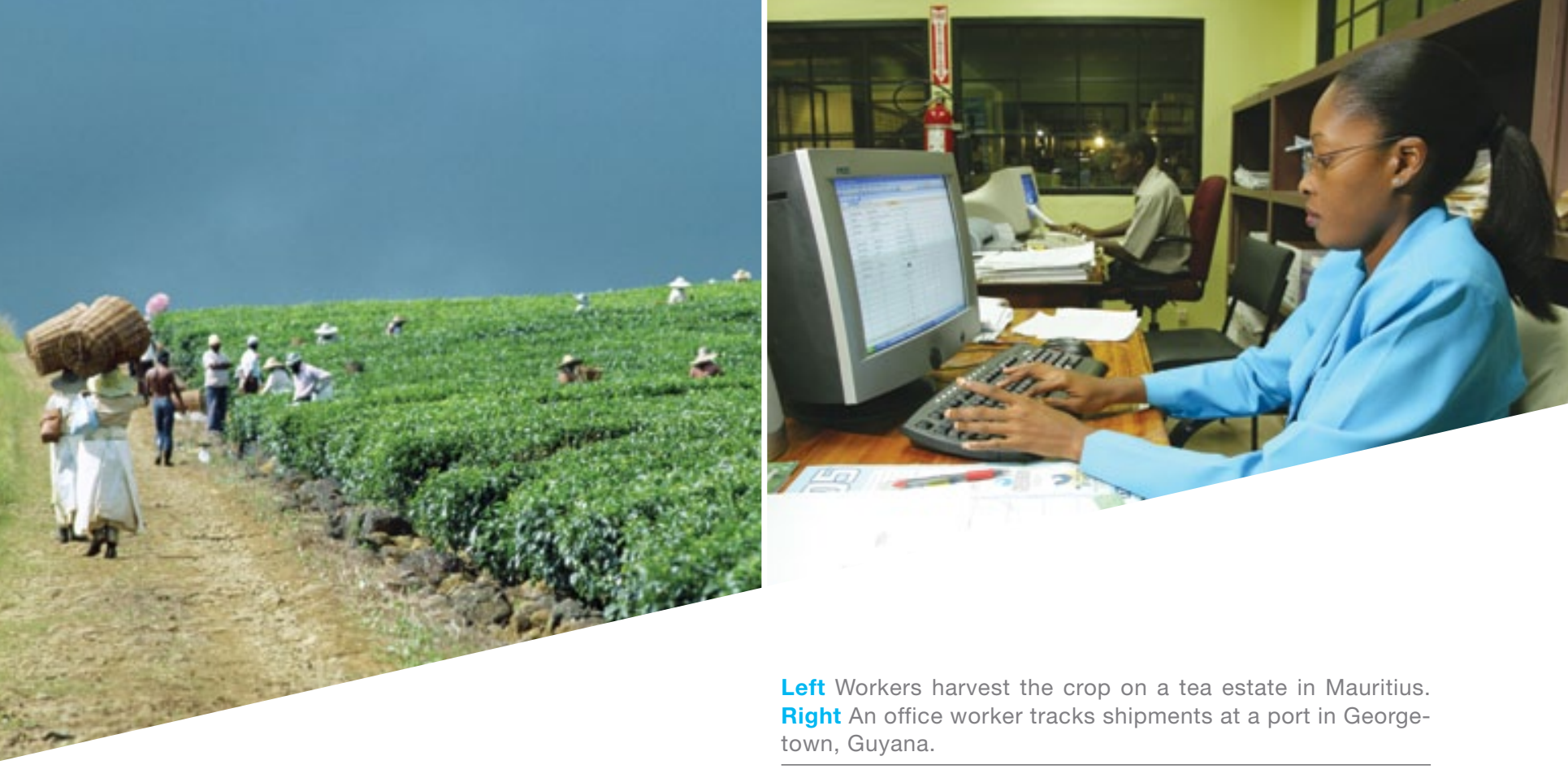

Table 4.1

IMF Institute training program, FY2008-12

$2008 \quad 2009 \quad 2010 \quad 2011$

2012

\begin{tabular}{lrrrrr}
\hline HEADQUARTERS & & & & & \\
$\begin{array}{l}\text { Course-weeks } \\
\text { Participant-weeks }\end{array}$ & 78 & 54 & 58 & 50 & 60 \\
& 2,813 & 1,974 & 1,992 & 1,861 & 2,271 \\
\hline REGIONAL TRAINING & CENTERS & & & & \\
Course-weeks & 172 & 158 & 163 & 178 & 195 \\
Participant-weeks & 5,280 & 4,737 & 5,067 & 5,329 & 5,819
\end{tabular}

OVERSEAS

\begin{tabular}{lrrrrr} 
Course-weeks & 35 & 42 & 36 & 36 & 46 \\
Participant-weeks & 1,071 & 1,211 & 1,012 & 1,012 & 1,239 \\
& & & & & \\
\hline $\begin{array}{l}\text { DISTANCE LEARNING } \\
\text { Course-weeks }\end{array}$ & 18 & 16 & 18 & 21 & 18 \\
Participant-weeks & 675 & 570 & 646 & 796 & 601 \\
& & & & & \\
\hline TOTAL & 303 & 270 & 275 & 284 & 319 \\
Course-weeks & 9,838 & 8,491 & 8,717 & 9,003 & 9,930 \\
Participant-weeks & & & & &
\end{tabular}

Source: IMF Institute for Capacity Development.

country adheres, it undertakes to meet the most rigorous data dissemination and data quality standards within the Fund's data standards initiatives.

\section{Eighth Review of the Fund's Data Standards Initiatives}

The Eighth Review of the Fund's Data Standards Initiatives was completed in February 2012. ${ }^{46}$ In their discussion, Executive Directors considered proposals for further enhancing the SDDS and the creation of the SDDS Plus as a new tier under these initiatives, given the need to fill data gaps to help prevent and mitigate financial crises. They expressed broad satisfaction with developments in the data standards initiatives since the Seventh Review in December 2008.

Executive Directors broadly supported proposed enhancements to the SDDS. They looked forward to the graduation of additional countries from the GDDS to the SDDS as national statistical systems strengthened, while recognizing that progress in this area was likely to proceed at a measured pace. In this regard, they highlighted the importance of continued outreach efforts and well-prioritized technical assistance.

Executive Directors broadly supported concrete proposals on the data categories and modalities of the SDDS Plus developed since the Interim Report for the Eighth Review in February 2011. They were encouraged to note that the proposed data categories and the modalities were developed in collaboration with other international institutions and capital markets and were guided by feedback from SDDS subscribers and some GDDS participants.

Executive Directors underscored the importance of continuing close collaboration with national authorities and relevant international bodies - in particular the FSB, the BIS, and the Inter-Agency Group on Economic and Financial Statistics-for the resolution of any procedural and operational issues that might arise in the future. Executive Directors generally agreed that the next review of the Fund's Data Standards Initiatives should take place in about two years.

\section{Other data-related activities}

The global crisis highlighted the crucial role played by data in crisis preparedness and prevention. In FY2012, the IMF continued its ongoing efforts to strengthen the quality of data provided by its members and increase the accessibility of the data it produces and manages (including, for the first time, a mobile application for IMF statistical data; see Box 4.3).

\section{CInternational Monetary Fund. Not for Redistribution}


Box 4.3

Mobile applications for IMF statistical data

As part of the Fund's effort to make statistical data more accessible, the IMF released a new mobile application (app) in the fall of 2011 that allows users of handheld devices (such as iPad, iPhone, iTouch, and Android) to access a broad range of IMF statistical data. The free app, IMF eLibrary, is integrated with social networking tools, enabling users to share data reports and comments with one another.

The app gives users access to a broad range of statistical data sets, including a selection from the International Financial Statistics. In addition, it provides access to the latest editions of nonstatistical IMF publications such as the World Economic Outlook, Global Financial Stability Report, Fiscal Monitor, and Regional Economic Outlook reports.

Considerable attention was devoted during the year to increasing or improving online access. Box 4.4 notes the inclusion of an online version in the release of Public Sector Debt Statistics: Guide for Compilers and Users. In July 2011, the IMF released the results of the second annual Financial Access Survey through the online survey database, which disseminates key indicators of geographic and demographic outreach of financial services, as well as the underlying data. ${ }^{47}$ About 140 countries participated in the 2011 survey, which included new data on outstanding deposits and loans of households, and the survey website now contains annual data for about 160 respondents covering a seven-year period (2004-10), including data for all G-20 countries. The supporting software tools were also upgraded. Also in July 2011, the IMF released, as an online database, expanded results from its
Users can easily access key indicators from a range of databases the IMF maintains, including International Financial Statistics, Direction of Trade Statistics, Government Finance Statistics, International Reserves, Coordinated Portfolio Investment Survey, Currency Composition of Official Foreign Exchange Reserves, Coordinated Direct Investment Survey, and Financial Soundness Indicators. Data access is available in the form of standard reports, and the data can be presented as tables and visualizations.

The app relies on the Statistical Data and Metadata Exchange standards for accessing the underlying data.

2009 Coordinated Direct Investment Survey, a worldwide survey of bilateral foreign direct investment positions; the following December, it released results from the 2010 survey. ${ }^{48}$ Country participation and geographical detail are being broadened over time, and the July 2011 release expanded the survey data to Azerbaijan, Bhutan, China, Ghana, Israel, Jordan, Kuwait, Mauritius, Moldova, Paraguay, the Russian Federation, and Samoa; new survey participants for the December 2011 release were Aruba, Brazil, FYR Macedonia, Georgia, India, Montenegro, Seychelles, and Uruguay. The survey website was also redesigned, for the December release, to facilitate user access to data reports, through enhanced navigation, data selection, and display features. Metadata coverage was also enhanced in terms of both information detail and number of metadata reporters.

Box 4.4

\section{Public Sector Debt Statistics: Guide for Compilers and Users}

With the heightened interest in public sector debt statistics, the IMF has developed a coordinated program involving a statistical guide, a database, regional seminars, and technical assistance to help improve these statistics. In December 2011, the IMF, in collaboration with the multiagency Task Force on Finance Statistics, published Public Sector Debt Statistics: Guide for Compilers and $U_{\text {sers, }}$ with an online version also available; ${ }^{\mathrm{a}}$ translations are also in production. The Guide is intended to help standardize classification of public sector debt liabilities and achieve more internationally comparable public sector debt data. It complements the World Bank-IMF Public Sector Debt Statistics database, which offers free access to public sector debt statistics for 54 countries.

The Guide is an important reference for national compilers and users, providing a comprehensive conceptual framework for the measurement of gross and net debt of the public sector and all its components. This guidance can be applied across the different components of the public sector and across various liabilities that constitute public sector debt. The Guide provides a structure for classifying debt liabilities by instrument and by sector of the counterpart to the debt instrument. It also offers valuable advice on practical problems in recording public sector debt, including numerical examples.

The Task Force on Finance Statistics is an interagency effort chaired by the IMF and including as members the Bank for International Settlements, the Commonwealth Secretariat, the European Central Bank, the Statistical Office of the European Communities (Eurostat), the Organisation for Economic Co-operation and Development, the Paris Club Secretariat, the United Nations Conference on Trade and Development, and the World Bank. 
In November 2011, the results of the 2010 Coordinated Portfolio Investment Survey-covering positions in equity and debt securities as of end-2010 for 73 participating economies-were published, and for the first time, a new online database that leverages current technologies for data and metadata dissemination replaced the previous spreadsheet format. ${ }^{49}$ Along with the launch of the improved database, the survey website was redesigned to offer enhanced navigation features, in line with other specialized IMF databases. Dynamic data selection and display features allow faster user access to data reports.

At the beginning of May 2011, the IMF's Statistics Department and the World Bank's Development Economics Data Group cohosted a global conference to promote and broaden implementation of Statistical Data and Metadata Exchange (SDMX) standards. ${ }^{50}$ The conference brought together more than 200 senior officials, statisticians, and information technology professionals from 90 countries to share SDMX implementation strategies and to participate in a capacity-building workshop aimed at national agencies that have not yet implemented SDMX. During the conference, the IMF launched a new iPhone and iPad application that relies on SDMX standards to display data tables and charts from the Principal Global Indicators website. ${ }^{51}$

At the end of April 2012, the IMF finalized agreement on the sectoral accounts data template as part of the implementation of the 2008 System of National Accounts for G-20 and advanced economies, which will come to fruition beginning in 2014 .

\section{COLLABORATION WITH GROUP OF TWENTY AND OTHER ORGANIZATIONS}

The IMF collaborates with a number of other organizations that are also involved in global economic issues. Of particular significance are its work with the G-20 advanced and emerging market economies and its collaborative efforts with regional financing arrangements, most notably in Europe.

\section{IMF collaboration with the G-20}

The IMF's collaboration with the G-20 has increased since the onset of the global financial crisis, when collective action by the G-20 was critical in avoiding even greater economic difficulties. At the request of G-20 leaders, the IMF provides technical analysis in support of the multilateral Mutual Assessment Process (MAP), through which G-20 countries identify objectives for the global economy, the policies needed to reach them, and the progress toward meeting these shared objectives. The IMF staff-with input from other international institutions - initially was tasked with analyzing whether policies pursued by individual G-20 countries were collectively consistent with the G-20's growth objectives. Subsequently, the staff has provided technical support to help develop indicative guidelines (benchmarks against which selected indicators would be assessed) to evaluate external imbalances and has also provided an assessment of progress achieved toward the common objectives.

Collaborative work with the G-20 extends beyond the MAP into other areas, including the G-20 Data Gaps Initiative, which works on ways to address gaps in data identified by the global crisis, and a G-20 report on effects of regulatory reforms on emerging market and developing economies.

Board review of experience with the Fund's involvement in the MAP

The Executive Board reviewed the IMF's role in the MAP in June $2011 .^{52}$ Executive Directors supported the continuation of Fund engagement in this work, which they observed has significant

Left A fisherman casts his net near Villeta, Paraguay. Right A worker at a plant in Yekaterinburg, Russia, which refines precious metals for use in industry.

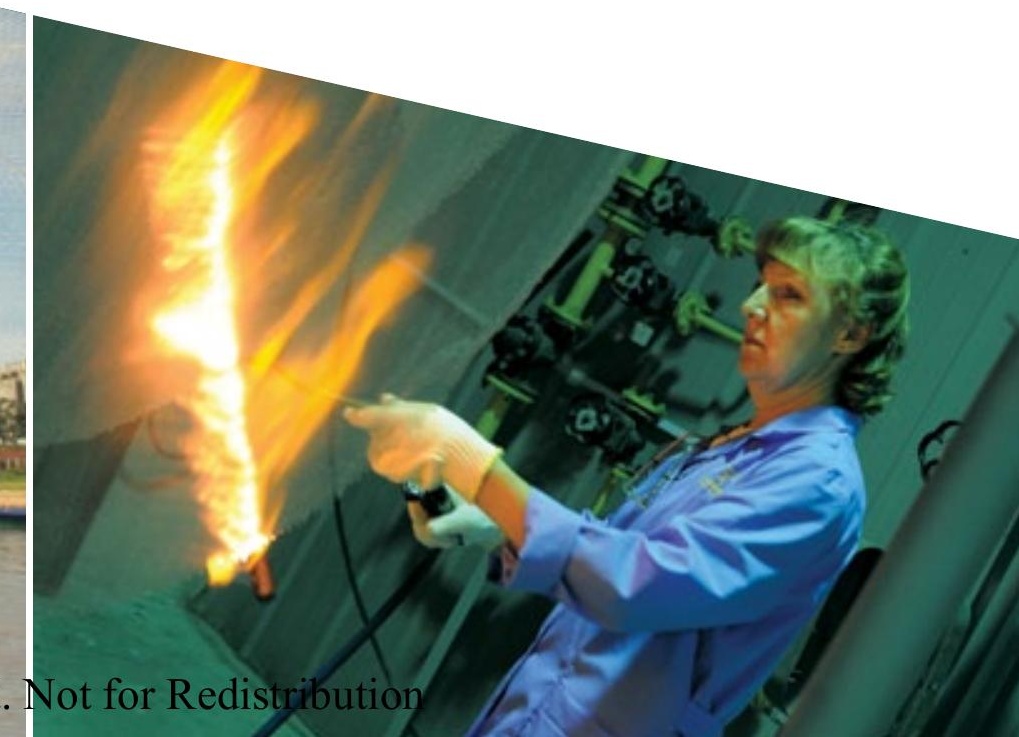


synergies with the Fund's surveillance, most notably at the multilateral level. Executive Directors considered it important to review the implications of broader G-20/IMF collaboration for the Fund's surveillance as part of the October 2011 Triennial Surveillance Review.

Executive Directors agreed that, while the MAP has evolved, the Fund's input into the exercise has remained within the framework set in December 2009. In this context, they took note that the legal nature of the Fund's involvement as technical assistance had not changed. Executive Directors concurred with the observation, in the IMF staff report that formed the basis for the discussion, that Executive Board involvement in this work should be consistent with G-20 ownership of the MAP and preserve the independent nature of IMF staff analysis and input. They appreciated timely briefings by the staff on their work in this regard.

Executive Directors considered resource implications of the Fund's involvement in the MAP. Most noted that any additional cost, which has in part been met through reprioritization and reallocation of existing resources, should be seen in light of the benefits of this work for the Fund's membership at large, including the synergies with the Fund's surveillance.

\section{Participation in regional financing arrangements}

IMF participation, early in the global financial crisis, in financing for EU members facing balance of payments needs (Hungary, Latvia, and Romania) led to an extension of the IMF's collaboration with EU institutions, in particular with the European Central Bank, later in the crisis, when euro area countries (Greece, Ireland, and Portugal) requested IMF support (see Box 3.1). This enhanced cooperation among the IMF, the European Commission, and the European Central Bank in program countries has become known as the "Troika." Although the IMF coordinates closely with the other members of the Troika, Fund decisions on financing and policy advice are ultimately taken, independently of the Troika process, by the Executive Board. Building on the recent experience of financing in cooperation with EU institutions, the IMF is exploring the scope for greater collaboration with other regional financing arrangements.

\section{Collaboration with other organizations}

The IMF is also a member of the Financial Stability Board, which brings together government officials responsible for financial stability in the major international financial centers, international regulatory and supervisory bodies, international standard-setting bodies, committees of central bank experts, and international financial institutions. The two groups collaborate on twice-yearly Early Warning Exercises and the Early Warning List (see "Risk Assessment and Management" in Chapter 3). In addition to being a member of the FSB, the IMF is also represented on its Steering
Committee and participates in various working groups, the Standing Committee on the Assessment of Vulnerabilities, and the Standing Committee on Standards Implementation, which draws on the IMF's work on the Financial Sector Assessment Program and Reports on the Observance of Standards and Codes. It also works with the FSB in connection with the G-20 Data Gaps Initiative; in FY2012, the two organizations jointly issued a progress report on implementation of previously identified measures to close information gaps revealed by the global crisis. ${ }^{53}$

The IMF and the World Bank collaborate regularly and at many levels to assist member countries. Through the HIPC Initiative and MDRI (discussed earlier in this chapter), they work together to reduce the external debt burdens of the most heavily indebted poor countries. Via the two organizations' shared Poverty Reduction Strategy Paper approach-a country-led plan for linking national policies, donor support, and the development outcomes needed to reduce poverty in low-income countriesthey cooperate to alleviate poverty. Their collaborative Global Monitoring Report assesses progress toward achieving the Millennium Development Goals; the 2012 edition had food prices and nutrition as a central theme. The two organizations also work together to make financial sectors in member countries resilient and well regulated, via the Financial Sector Assessment Program. A joint IMF-World Bank technical assistance program funded by the Canadian International Development Agency is underway in Caribbean countries.

Collaboration between the IMF and the United Nations covers a number of areas of mutual interest, including cooperation on tax issues and statistical services of the two organizations, as well as reciprocal attendance and participation at regular meetings and specific conferences and events. In recent years, the IMF has worked with the International Labour Organization on issues related to employment, as well as social protection floors, the UN Children's Fund on fiscal issues and social policy, the UN Environment Programme on the green economy, and the World Food Program on social safety nets and early assessments of vulnerability.

The IMF participates in the Deauville Partnership of Arab countries in transition, regional partner countries, the Group of Eight, and regional and international financial institutions, launched in May 2011. The regional and international financial institutions participating in the partnership agreed in September 2011 to establish a dedicated Deauville Partnership coordination platform to ensure effective support for the partner countries; facilitate information sharing, mutual understanding, and the operational dialogue with the partner countries; coordinate monitoring and reporting of joint actions in support of the partnership; and identify opportunities for collaboration on financial assistance, technical assistance, and policy and analytical work. 


\section{GOVERNANCE, FINANCES, AND ACCOUNTABILITY}

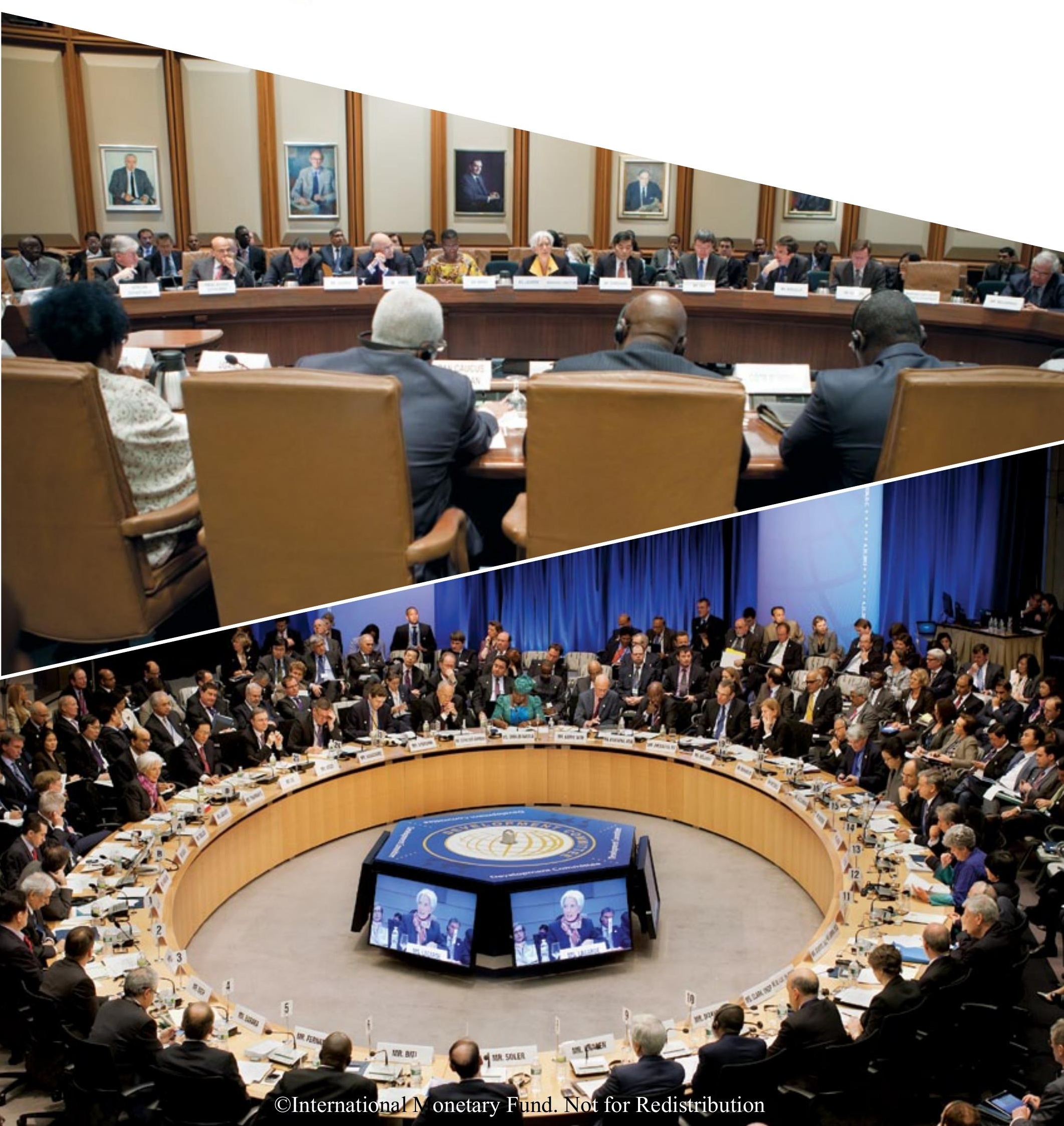




\section{GOVERNANCE, FINANCES, AND ACCOUNTABILITY}

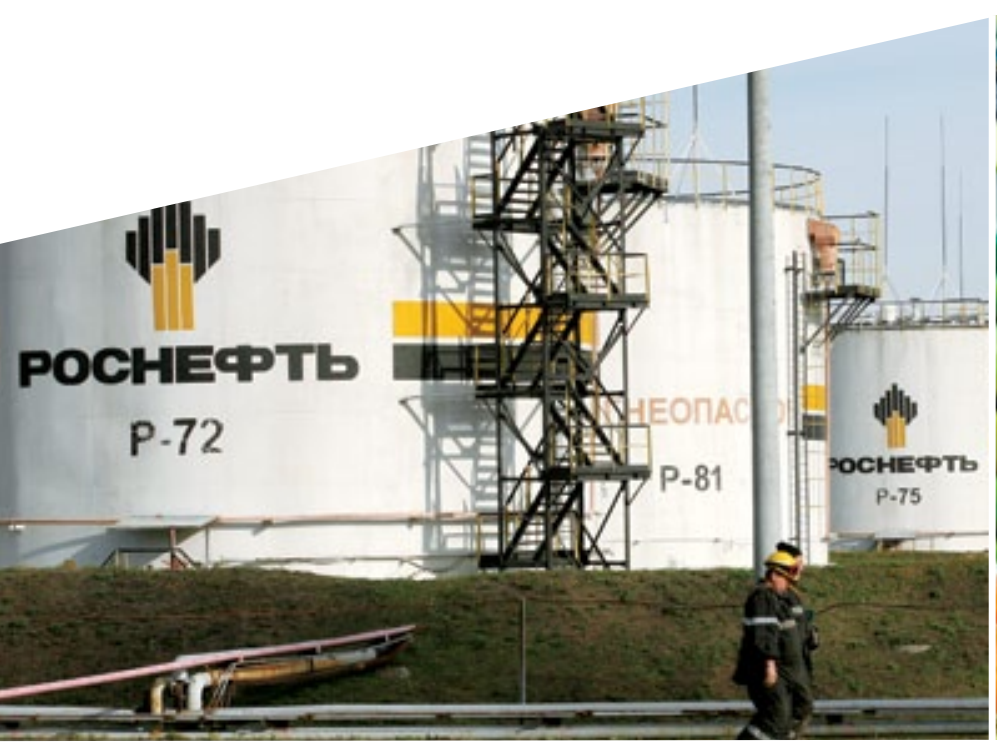

QUOTA AND GOVERNANCE REFORM

Quota subscriptions (see Web Box 5.1) are a major source of the IMF's financial resources. The IMF's Board of Governors conducts general quota reviews at regular intervals (at least every five years), allowing the IMF to assess the adequacy of quotas in terms of members' financing needs and its own ability to help meet those needs, and to modify members' quotas to reflect changes in their relative positions in the world economy, thus ensuring that the decision-making mechanism of the international financial system evolves with the changing structure of the global economy. The most recent of these reviews, the Fourteenth General Review of Quotas, was concluded in December 2010.

\section{Progress on the 2010 quota and governance reform}

In December 2010, the Board of Governors approved a quota and governance reform in connection with the completion of the Fourteenth General Review and a proposed amendment of the IMF's Articles of Agreement on the reform of the Executive Board. The reform package, once accepted by the membership, will double quotas to approximately SDR 476.8 billion (about US $\$ 739.0$ billion), shift more than 6 percent of quota shares to dynamic emerging market and developing economies and from overrepresented to underrepresented countries (exceeding the 5 percent target set by the IMFC in 2009), and protect the quota shares and voting power of the poorest members. With this shift, Brazil and India will be among the Fund's 10 largest shareholders, which would also include the United States, Japan, China, France, Germany, Italy, the Russian Federation, and the United Kingdom. In addition, the 2010 reform will lead to an all-elected Executive Board, the combined representation of advanced European economies on the Board will decrease by two Executive Director positions, and there will be further scope for appointing second Alternate Executive Directors to enhance representation of multicountry constituencies. A comprehensive review of the quota formula will be completed by January 2013, and completion of the Fifteenth General Review of Quotas will be moved up to January 2014. A comparative table of quota shares before and after implementation of the reform is available on the IMF's website. ${ }^{54}$

For the quota increases to become effective, two conditions must be met: (1) the proposed amendment to reform the Executive Board must enter into force, which requires acceptance of the amendment by three-fifths of members having 85 percent of the Fund's total voting power, and (2) members holding not less than 70 percent of total quotas as of November 5, 2010, must consent to the increase. When it approved the reform, the Executive Board endorsed a timeline that called for the quota increase and realignments and the proposed amendment on Executive Board reform to take effect by the 2012 Annual Meetings. 
In December 2011 and March 2012, the Executive Board reviewed progress toward implementation of the 2010 quota reform package. Executive Directors were informed at both reviews that the necessary legal thresholds required for effectiveness of the reforms had not yet been reached. That remained the case at the end of FY2012: 100 members having 57.93 percent of quotas as of November 5, 2010, had consented to their proposed quota increases under the Fourteenth General Review; 75 members having 46.85 percent of the total voting power had accepted the proposed amendment to reform the Executive Board. During the progress reviews, the Managing Director urged the remaining countries to complete the necessary legislative steps and other legal measures quickly to implement this important agreement within the agreed-upon timeframe.

\section{Review of the quota formula}

As noted previously, the 2010 quota and governance reform called for a comprehensive review of the quota formula by January 2013 and completion of the Fifteenth General Review of Quotas by January 2014. As a first step toward these goals, in March 2012, the Executive Board initiated formal discussions on the review of the formula for determining members' quotas. ${ }^{55}$

Executive Directors stressed the importance of agreeing on a quota formula that better reflects members' relative positions in the global economy for future discussions on the Fifteenth General Review. Most Executive Directors agreed that the principles that underpinned the 2008 reform of the quota formula remain broadly relevant: that the formula should be simple and transparent, be consistent with the multiple roles of quotas, produce results that are broadly acceptable to the membership, and be feasible to implement statistically based on timely, high-quality, and widely available data.

Executive Directors generally concurred that GDP is the most comprehensive measure of economic size and should continue to have the largest weight in the quota formula. ${ }^{56} \mathrm{~A}$ range of views were expressed on the relative importance of market versus purchasing power parity GDP in the GDP blend variable. Many Executive Directors noted that openness is a measure of members' integration into the world economy and should remain an important variable in the quota formula. Many of these Executive Directors saw merit in further exploring options for better capturing financial openness.

Executive Directors took note of the IMF staff's finding that there is little empirical evidence of a relationship between variability of current receipts and net capital flows and potential demand for Fund resources. Most Executive Directors considered that reserves remain an important indicator of a member's financial strength and ability to contribute to the Fund's finances. Many Executive Directors supported, or could support, further work on the scope for capturing members' financial contributions to the Fund in the quota formula, either instead of, or as a complement to, reserves. Other Executive Directors viewed the inclusion of voluntary financial contributions in the formula as inconsistent with the Fund's role as a quota-based institution.

Recognizing the difficult compromise in 2008 on the use of compression ${ }^{57}$ to moderate the role of size in the formula and better protect the voice of smaller members and low-income countries, many Executive Directors supported retaining the compression factor.

\section{RESOURCES, INCOME, AND BUDGET}

\section{Borrowing agreements}

New Arrangements to Borrow

To supplement its quota resources, the IMF has two standing sets of credit lines, the General Arrangements to Borrow (established in 1962) and the New Arrangements to Borrow (established in 1998). Under these arrangements, a number of member countries or their institutions stand ready to lend additional funds to the IMF, through activation of the arrangements.

The NAB was expanded and enlarged with new participants in FY2011 to increase available resources for providing financing. In FY2012, the National Bank of Poland joined the NAB, with a commitment of SDR 2.5 billion (US $\$ 3.9$ billion). Total resources available under the NAB as of April 30, 2012, amounted to nearly SDR 370 billion (US\$574 billion).

After the expansion was ratified by NAB participants, the expanded NAB became effective in March 2011, and it was activated for the first time in April 2011, for the maximum six-month period permitted. ${ }^{58}$ With that activation approaching its termination date, the Board approved another six-month activation period in September 2011, with the activation to begin October 1, 2011, and subsequently approved another six-month activation period beginning April 1, 2012. Between the initial activation and April 30, 2012, SDR 53 billion (US\$82.15 billion) was committed under Fund-supported programs, and actual drawings under the NAB, including bilateral claims folded in, amounted to SDR 39.8 billion (US\$61.69 billion).

\section{Proposed rollback of the NAB}

In the context of the agreement in December 2010 to double the IMF's quota resources under the Fourteenth General Review, it was agreed that there should be a corresponding rollback of the NAB, resulting in a shift in the composition of the Fund's lending resources from the NAB to quotas, while not reducing the overall lending capacity. The rollback required Executive Board approval, which was given in December 2011; that approval included necessary technical decisions for implementing the 
rollback. The rollback now requires the consent of participants representing 85 percent of total credit arrangements under the $\mathrm{NAB}$, including each participant whose credit arrangement is being reduced. Once the required consents are obtained, the rollback would become effective for each NAB participant on the same day as the quota increase for the relevant member under the Fourteenth General Review.

\section{Bilateral agreements}

As part of an international effort to strengthen the adequacy of the global resources available to prevent and fight crises and to promote global economic stability, a number of IMF member countries, including those in the euro area, pledged additional support in FY2012 via bilateral loans and note purchase agreements. Euro area members pledged $€ 150$ billion (about US $\$ 200$ billion) in December 2011; ${ }^{59}$ additional pledges in April 2012 from Japan (US\$60 billion), the Republic of Korea (US\$15 billion), Saudi Arabia (US\$15 billion), the United Kingdom (US\$15 billion), Sweden (at least US\$10 billion), Switzerland (US $\$ 10$ billion), Norway (SDR 6 billion, about US\$9.3 billion), Poland (€6.27 billion, about US\$8 billion), Australia (US\$7 billion), Denmark's Nationalbank ( $€ 5.3$ billion, about US\$7 billion), ${ }^{60}$ Singapore (US $\$ 4$ billion), and the Czech Republic ( $€ 1.5$ billion, about US $\$ 2$ billion), along with pledges from China, Russia, Brazil, India, Indonesia, Malaysia, Thailand, and other countries, brought the total to US $\$ 430$ billion by the end of the financial year. ${ }^{61}$ Should it become necessary to use these resources, once they are available, adequate risk mitigation features and adequate burden sharing among official creditors would apply, as approved by the Executive Board.

Agreements in support of financing for low-income countries

In 2009, following a reform of its concessional financing facilities, the IMF launched a fundraising campaign seeking additional bilateral loan resources and subsidy contributions to support concessional financing under the PRGT. Loan agreements or note purchase agreements with 12 members were signed in FY2010 and FY2011. In FY2012, the IMF signed an additional bilateral loan agreement with the Saudi Arabian Monetary Authority to provide SDR 500 million (US\$775 million), bringing total additional resources secured for concessional financing to SDR 9.46 billion as of the close of FY2012.

\section{Income, charges, remuneration, and burden sharing}

Review of the Fund's charges and maturities

Income

Since its inception, the IMF has relied primarily on its lending activities to fund its administrative expenses. A reform of the Fund's income model approved by the Board of Governors in
May 2008 allows the IMF to diversify its sources of income through the establishment of an endowment funded within the Investment Account with the profits from a limited sale of the Fund's gold holdings (see "Gold Sales" later in the chapter), a broadening of the IMF's investment authority to enhance returns on investments, and resumption of the practice of reimbursing the Fund for the cost of administering the PRGT.

Broadening the Fund's investment authority required an amendment of the Articles of Agreement, and in February 2011, the amendment became effective, following ratification by the membership with the required majorities. The amendment provides authority to expand the range of instruments in which the IMF may invest, in accordance with rules and regulations to be adopted by the Executive Board. Currencies in an amount equivalent to the gold sale profits of SDR 6.85 billion were transferred from the General Resources Account to the Investment Account in March 2011 and invested. The endowment envisioned in the IMF's revised income model is expected to be established following adoption by the Executive Board of new rules and regulations for the expanded investment authority authorizing such an endowment.

Charges

The main sources of IMF income continue to be its financing activities and investments. As noted in Chapter 3, the basic rate of charge (the interest rate on IMF financing) comprises the SDR interest rate plus a margin expressed in basis points. For FY2013 and FY2014, the Executive Board agreed to keep the margin for the rate of charge unchanged from FY2012, at 100 basis points. The margin was adopted under a new rule for setting the basic rate of charge adopted by the Executive Board in December 2011. ${ }^{62}$ The new rule, effective for FY2013 onward, is an important step in fully implementing the revised income model, under which the margin is set so as to cover the IMF's lending-related intermediation costs and allow for a buildup of reserves. In addition, the new rule includes a cross-check to ensure that the rate of charge maintains a reasonable alignment against long-term credit market conditions. Consistent with the Board-endorsed principle that the margin should be stable and predictable, the margin is set for a period of two financial years starting with FY2013-14.

Surcharges of 200 basis points are levied on the use of large amounts of credit (above 300 percent of a member's quota) in the credit tranches ${ }^{63}$ and under extended arrangements; these are referred to as "level-based surcharges." The IMF also levies "time-based surcharges" of 100 basis points on the use of large amounts of credit (with the same threshold as above) that remains outstanding for more than 36 months.

In addition to periodic charges and surcharges, the IMF also levies service charges, commitment fees, and special charges. A service charge of 0.5 percent is levied on each drawing from the General Resources Account. A refundable commitment fee is charged on 
amounts available under GRA arrangements, such as Stand-By Arrangements, as well as Extended, Flexible Credit Line, and Precautionary and Liquidity Line arrangements, during each twelve-month period. Commitment fees are levied at 15 basis points on amounts available for drawing up to 200 percent of a member's quota, 30 basis points on amounts in excess of 200 percent and up to 1,000 percent of quota, and 60 basis points on amounts more than 1,000 percent of quota. The fees are refunded when credit is used, in proportion to the drawings made. The IMF also levies special charges on overdue principal payments and on charges that are past due by less than six months.

\section{Remuneration and interest}

On the expenditure side, the IMF pays interest (remuneration) to members on their creditor positions in the GRA (known as "reserve tranche positions"). The Articles of Agreement provide that the rate of remuneration shall be not more than the SDR interest rate, nor less than 80 percent of that rate. The rate of remuneration is currently set at the SDR interest rate, which is also the current interest rate on IMF borrowing.

In 2009, the Executive Board agreed to boost the IMF's financing capacity, via borrowings, as part of its near-term response to the global financial crisis. As of April 30, 2012, the IMF had SDR 40.05 billion in borrowings outstanding under bilateral loans and note purchase agreements and under the enlarged and expanded NAB (see also "Borrowing Agreements" earlier in the chapter).

\section{Burden sharing}

The IMF's rates of charge and remuneration are adjusted under a burden-sharing mechanism established in the mid-1980s that distributes the cost of overdue financial obligations equally between creditor and debtor members. Quarterly interest charges that are overdue (unpaid) for six months or more are recovered by increasing the rate of charge and reducing the rate of remuneration (burdensharing adjustments) to make up for the lost income. The amounts thus collected are refunded when the overdue charges are settled.

In FY2012, the adjustments for unpaid quarterly interest charges averaged less than 1 basis point, reflecting the rise in IMF credit outstanding owing to the effects of the global crisis on members and a similar increase in member reserve tranche positions. The adjusted rates of charge and remuneration averaged 1.30 percent and 0.30 percent, respectively, in FY2012.

Net income

The IMF had net income in FY2012 of SDR 1.5 billion, reflecting primarily income from the high levels of financing activity. Investment income was SDR 169 million, representing returns net of fees of 126 basis points.

\section{Gold sales}

As noted earlier in the chapter, the revised income model for the IMF approved in 2008 includes the establishment of an endowment in the IMF's Investment Account funded from the profits of the sale of a limited portion of the Fund's gold holdings, with the objective of investing these resources and generating returns to contribute support to the IMF's budget while preserving the endowment's long-term real value. The Executive Board agreed in July 2009 that in addition to funding the endowment, part of the gold sale proceeds would also be used to increase the IMF's resources for concessional financing to low-income countries. The Board approved the sale of 403.3 metric tons of gold in September 2009, representing one-eighth of the institution's total holdings.

The gold sales were initiated in October 2009 and concluded in December 2010, generating total proceeds of SDR 9.54 billion. Of this amount, SDR 2.69 billion represented the gold's book value and SDR 6.85 billion represented profits. All sales were based on market prices, which were higher than assumed at the time the revised income model was endorsed. Funding the endowment with gold profits at the level assumed at that time, and increasing resources for concessional financing to the levels agreed upon in July 2009, would have required an average sales price of US\$935 per ounce. The actual average sales price was US $\$ 1,144$ per ounce, resulting in additional "windfall" profits from the gold sales.

Use of gold sale profits

In a preliminary discussion on the use of the gold sale profits in FY2011, ${ }^{64}$ the Executive Board agreed that at least SDR 4.4 billion (US\$6.8 billion) of the profits would be used to fund the endowment within the IMF's Investment Account, as mentioned earlier. Executive Directors also affirmed their support for a strategy to use part of the profits to generate SDR 0.5-0.6 billion, in end-2008 net present value terms, in resources for subsidies for the PRGT. For this purpose, in February 2012, the Board approved a distribution to all IMF members of SDR 0.7 billion (US $\$ 1.1$ billion) in reserves attributed to a portion of the windfall profits from the gold sales (see "Concessional Financing" in Chapter 3), with the expectation that the recipient member countries would contribute the distributed resources to the PRGT. ${ }^{65}$

In September 2011, the Executive Board held a follow-up discussion focused on options for using the remaining windfall profits of SDR 1.75 billion (US $\$ 2.7$ billion), which had been placed in the general reserve. ${ }^{66}$ Many Executive Directors continued to support using resources linked to the remaining gold windfall profits as part of a strategy to assist low-income countries. In particular, many were in favor of, or open to, using these resources as part of a strategy to bolster the PRGT's capacity to provide concessional assistance to low-income countries. Many Executive Directors supported, or were willing to consider, counting the remaining windfall profits toward the Fund's precautionary balances, in light of the Fund's elevated 
credit exposure. A number of Executive Directors supported, or were willing to consider, adding the remaining windfall profits to the Fund's endowment, which would help ensure a sustainable and diversified income base, as envisaged under the revised income model, particularly given the uncertain prospects for investment returns from the endowment.

Executive Directors recognized that choosing among these main options involved trade-offs in financial policy implications. Some could support a combination of options, though such an approach would limit progress toward each individual objective. Given the lack of a consensus at the time of the discussion, most Executive Directors were willing to support a sequenced approach, under which the remaining windfall would remain in the Fund's general reserve and would continue to be invested on an interim basis in the Investment Account, but not be counted toward precautionary balances, on the understanding that the Board would revisit the ultimate use of the windfall profits in a year's time. This approach would allow time for greater clarity to emerge regarding the global outlook, the Fund's income position and credit risks, and the evolution of demand for concessional financing. A number of Executive Directors would have preferred to take a decision on the use of the windfall without further delay.

Executive Directors will continue to explore options on how to use the remaining windfall profits. It was decided that in the interim, the windfall profits would remain in the Investment Account and be invested in short-term deposits.

\section{Box 5.1}

\section{Building renovations}

The IMF's main capital expenditures over the medium term will be on repairs and renovation of the main headquarters (HQ1) and Concordia buildings. Following several consultations with the Committee on the Budget about renovation options for both buildings, the Executive Board approved funding for the projects, as well as project-specific governance and financial control frameworks (over and above the Fund's standard governance and control measures) that include project review teams, and in the case of HQ1, an external peer reviewer. Both of these projects were approved by the Executive Board in the context of the FY2012-14 medium-term budget.

HQ1. Studies culminating in FY2011 revealed that most of the building and its major systems, almost 40 years old, have exceeded or are reaching the end of their useful lives, and substantial investments are required to replace a number of key building systems to ensure safety, energy efficiency, and more rational use of space. After consideration of a number of alternative approaches, the least costly approach—renovating two floors at a time-was

\section{Administrative and capital budgets}

In April 2011, in the context of the FY2012-14 medium-term budget, the Executive Board authorized total net administrative expenditures for FY2012 of US\$985 million as well as a limit on gross expenditures of US $\$ 1,123$ million (see Table 5.1) ${ }^{67}$ In addition, the Board approved up to US $\$ 34$ million in carry-forward of unspent FY2011 resources. It also approved capital expenditures of US\$162 million, the bulk of which were for renovations of the Concordia building and to start detailed planning for the renovation of the aging main headquarters building (see Box 5.1).

The IMF's work during FY2012 continued to be affected by the ongoing global crisis, and the approved budget aimed to provide sufficient resources to allow the organization to meet the associated needs of the membership. Relative to the previous financial year, which represented the final year of the Fund's three-year restructuring and downsizing effort, the budget was increased by 3 percent in real terms to fund changes in the Fund's core work that will be sustained well beyond the current crisis, for example, work on crisis prevention, cross-country analysis, and financial sector surveillance. Within the authorized limit, the FY2012-14 medium-term budget also included US\$53 million in crisis-related temporary expenditures, which in FY2011 had been financed from unspent resources carried forward from FY2010 and authorized for spending in FY2011.

approved, despite its greater inconvenience to the IMF staff. In FY2012, management approved the architect's conceptual design for the renovation, which is expected to meet the IMF's business requirements and place the building in good operational condition for two decades. The repairs and renovation will be carried out over four years beginning in 2013.

Concordia facility. In accordance with the approach recommended by the IMF staff and approved in FY2011, renovations began in FY2012 on the 46-year-old Concordia building, to address structural and systems issues and bring the building up to modern standards, and the building is projected to reopen in spring 2013. The 81-year-old Bond building was put on the market and competitively sold in January 2012 for about US $\$ 22$ million; the net proceeds from the sale were credited to the General Resources Account. The two buildings were part of the Concordia extended-stay facility, used primarily to house students attending courses at the former IMF Institute (now part of the Institute for Capacity Development; see Chapter 4). 
Table 5.1

Budget by major expenditure category, FY2011-15

(Millions of U.S. dollars)

\begin{tabular}{|c|c|c|c|c|c|c|c|}
\hline & \multicolumn{2}{|c|}{ FY2011 } & \multicolumn{2}{|c|}{ FY2012 } & \multirow{2}{*}{$\begin{array}{l}\text { FY2013 } \\
\text { Budget }\end{array}$} & \multirow{2}{*}{$\begin{array}{l}\text { FY2014 } \\
\text { Budget }\end{array}$} & \multirow{2}{*}{$\begin{array}{l}\text { FY2015 } \\
\text { Budget }\end{array}$} \\
\hline & Budget & Outturn & Budget & Outturn & & & \\
\hline \multicolumn{8}{|l|}{ ADMINISTRATIVE } \\
\hline Personnel & 739 & 757 & 820 & 799 & 836 & 847 & 854 \\
\hline Travel & 104 & 94 & 112 & 105 & 118 & 121 & 122 \\
\hline Buildings and other & 169 & 169 & 181 & 178 & 181 & 180 & 182 \\
\hline Annual Meetings & - & - & - & - & 6 & - & - \\
\hline TOTAL GROSS BUDGET & 1,013 & 1,021 & 1,123 & 1,082 & 1,159 & 1,164 & 1,171 \\
\hline Receipts $^{1}$ & -122 & -104 & -138 & -136 & -161 & -168 & -169 \\
\hline TOTAL NET BUDGET & 891 & 917 & 985 & 947 & 997 & 997 & 1,002 \\
\hline Carry-forward ${ }^{2}$ & 62 & $\ldots$ & 34 & $\ldots$ & 41 & & \\
\hline CARRY-FORWARD & 953 & 917 & 1,019 & 947 & 1,038 & 997 & 1,002 \\
\hline \multicolumn{8}{|l|}{ CAPITAL } \\
\hline Facilities and information technology & 48 & 54 & 162 & 44 & 388 & 35 & 35 \\
\hline
\end{tabular}

Note: Components may not sum to totals because of rounding.

1 Includes donor-financed activities, cost-sharing arrangements with the World Bank, sales of publications, parking, and other miscellaneous revenue.

2 Resources carried forward from the previous year under established rules.

Actual net administrative expenditures in FY2012 amounted to US\$947 million, US\$38 million below the authorized level, mainly as a result of lower-than-planned expenses for personnel. New staffing positions that were authorized as part of the FY2012 budget were filled with some lags. Actual spending on capital information technology (IT) and facilities was largely as planned. Capital budget appropriations are approved for a period of three years, with proportionally lower spending typically in the first year, as most projects span a longer period. IT investments focused on improving information and data management, IT security, operational efficiencies, and replacing technology that was outdated or no longer supported.

For financial-reporting purposes, the IMF's administrative expenses are accounted for in accordance with International Financial Reporting Standards rather than on a cash basis of budgetary outlays. These standards require accounting on an accrual basis and the recording and amortization of employee benefit costs based on actuarial valuations. Table 5.2 provides a detailed reconciliation between the FY2012 net administrative budget outturn of US\$947 million and the International Financial Reporting Standards-based administrative expenses of SDR 613 million (US\$948 million) reported in the IMF's audited financial statements for the year.
In April 2012, the Executive Board approved a budget for FY2013, including net administrative expenditures of US\$997 million and a limit on gross administrative expenditures of US\$1,159 million, as well as a US\$41 million in carry-forward of unspent FY2012 resources. The limit on net administrative expenditures for FY2013 remained unchanged in real terms relative to that in the previous year. The capital budget was set at US\$388 million to finance necessary investments in facilities and IT. The Executive Board also endorsed an indicative budget for FY2014-15.

The FY2013-15 medium-term budget aims to strike a balance between continued pressures on the IMF related to its active role in the global effort to restore financial stability and the desire to preserve the gains from the completed restructuring. The budget preserves the level of temporary crisis-related resources approved in FY2012. At the same time, and to ensure that resources are not diverted from nonsystemic surveillance cases, other new demands are being met through a combination of reallocation measures involving streamlining and refocusing selected multilateral surveillance products (both focus and frequency) and other efficiency measures (for example, the merger of two departments; see "Building Capacity in Member Countries" in Chapter 4). 
Table 5.2

Administrative expenses reported in the financial statements

(Millions of U.S. dollars, unless otherwise indicated)

FY2012 NET ADMINISTRATIVE BUDGET OUTTURN

Timing differences

Pension and postemployment benefits costs

Capital expenditure-amortization of current and prior years' expenditure

\section{Amounts not included in the administrative budget}

Capital expenditure_-items expensed immediately in accordance with International Financial Reporting Standards 7

Gain on sale of fixed assets

Reimbursement to the General Department (from the Post-Catastrophe Debt Relief Trust and Special Drawing Rights Department)

MEMORANDUM ITEM

Total administrative expenses reported in the audited financial statements (millions of SDRs)

Sources: IMF Finance Department and Office of Budget and Planning.

Note: Components may not sum exactly to totals because of rounding. Conversions are based on the effective weighted average FY2012 U.S. dollar/SDR exchange rate for expenditures of about 1.55 .

Table 5.3

Arrears to the IMF of countries with obligations overdue by six months or more and by type (Millions of SDRs; as of April 30, 2012)

\begin{tabular}{lrrrr} 
& & \multicolumn{3}{c}{ By type } \\
\cline { 3 - 6 } & Total & $\begin{array}{r}\text { General Department } \\
\text { (including Structural Adjustment Facility) }\end{array}$ & $\begin{array}{r}\text { Trust Fund } \\
\text { Poverty Reduction } \\
\text { and Growth Trust }\end{array}$ \\
\hline Somalia & 232.8 & 224.6 & 8.2 & - \\
Sudan & 982.6 & 901.4 & - & - \\
Zimbabwe & 85.9 & - & - & 85.9 \\
\hline Total & $\mathbf{1 , 3 0 1 . 2}$ & $\mathbf{1 , 1 2 5 . 9}$ & $\mathbf{8 9 . 4}$ & $\mathbf{8 5 . 9}$
\end{tabular}

Source: IMF Finance Department.

\section{Arrears to the IMF}

Overdue financial obligations to the IMF fell from SDR 1,305 million at end-April 2011 to SDR 1,301 million at end-April 2012 (Table 5.3). Sudan accounted for 75.5 percent of remaining arrears, and Somalia and Zimbabwe for 17.9 and 6.6 percent, respectively. At end-April 2012, all arrears to the IMF were protracted (outstanding for more than six months); one-third consisted of overdue principal, the remaining two-thirds of overdue charges and interest. More than four-fifths represented arrears to the GRA, and the remainder to the Trust Fund and the PRGT. Zimbabwe is the only country with protracted arrears to the PRGT. The general SDR allocation in August 2009 has facilitated all protracted cases in remaining current in the SDR Department.

Under the IMF's strengthened cooperative strategy on arrears, remedial measures have been applied to address the protracted arrears. At the end of the financial year, Somalia and Sudan remained ineligible to use GRA resources. Zimbabwe will not be able to access GRA resources until it fully settles its arrears to the PRGT. A declaration of noncooperation, the partial suspension of technical assistance, and the removal from the list of PRGT-eligible countries remain in place as remedial measures related to Zimbabwe's outstanding arrears to the PRGT. In April 2012, the Executive Board decided to continue the Fund's technical assistance to Zimbabwe in targeted areas.

\section{Audit mechanisms}

The IMF's audit mechanisms comprise an external audit firm, an internal audit function, and an independent External Audit Committee (EAC) that, under the Fund's By-Laws, exercises general oversight over the annual audit.

\section{External Audit Committee}

The EAC has three members, selected by the Executive Board and appointed by the Managing Director. Members serve three-

\section{CInternational Monetary Fund. Not for Redistribution}


year terms on a staggered basis and are independent of the Fund. EAC members are nationals of different member countries and must possess the expertise and qualifications required to carry out the oversight of the annual audit. Typically, EAC members have significant experience in international public accounting firms, the public sector, or academia.

The EAC selects one of its members as chair, determines its own procedures, and is independent of the IMF's management in overseeing the annual audit. It meets in Washington, D.C., each year, normally in January or February to conduct a midyear review, in June after the completion of the audit, and in July to report to the Executive Board. The IMF staff and the external auditors consult with EAC members throughout the year. The 2012 EAC members were Arfan Ayass, Amelia Cabal (chair), and Jian-Xi Wang.

\section{External audit firm}

The external audit firm, which is selected by the Executive Board in consultation with the EAC and appointed by the Managing Director, is responsible for conducting the IMF's annual external audit and expressing an opinion on its financial statements; accounts administered under Article V, Section 2(b), of the Articles of Agreement; and the Staff Retirement Plan. At the conclusion of the annual audit, the EAC briefs the Executive Board on the results of the audit and transmits the report issued by the external audit firm, through the Managing Director and the Executive Board, for consideration by the Board of Governors.

The external audit firm is normally appointed for five years. Deloitte \& Touche LLP is currently the IMF's external audit firm. It issued an unqualified audit opinion on the IMF's financial statements for the financial year ended April 30, 2012.

Office of Internal Audit and Inspection

The IMF's internal audit function is assigned to the Office of Internal Audit and Inspection (OIA), which independently examines the effectiveness of the Fund's risk management, control, and governance processes. The OIA's audit coverage includes Fund staff, and, since 2011, the Executive Board, offices of Executive Directors, and the Independent Evaluation Office and its staff.

The OIA conducted 16 audits and reviews in FY2012 in the following areas: financial audits on the adequacy of controls and procedures to safeguard and administer the IMF's financial assets and accounts, IT audits to evaluate the adequacy of IT management and the effectiveness of security measures, and operational and effectiveness reviews of work processes, associated controls, and the efficacy of operations in meeting the Fund's overall goals. In addition, the OIA conducted five advisory and special reviews to help in streamlining business processes to facilitate the implementation of internal development projects, and to provide input and coordination support for special reviews of the Fund. It completed two investigations that started in FY2011.

Separate from its internal audit function, the OIA also serves as Secretariat to the Advisory Committee on Risk Management. In this capacity, the OIA coordinates production of an annual risk management report to the Board. OIA also provided technical and logistical assistance in FY2012 to the external panel convened to review the Fund's risk management framework (see the next subsection, "Risk Management").

In line with best practices, the OIA reports to IMF management and to the External Audit Committee, thus ensuring its objectivity and independence. The Executive Board is informed of OIA activities twice a year, via an activity report that includes information on its planned audits and reviews, as well as the results and status of audit recommendations, and all audit reports are shared with the Board. The final informal Board briefing on these matters for FY2012 took place in January 2012. No significant weaknesses in the Fund's internal control structure and financial statements were identified, while the closure level for recommendations in FY2012 lagged behind that for FY2011.

\section{Risk management}

Efforts continued in FY2012 to strengthen the IMF's risk management framework. The Advisory Committee on Risk Management provides a cross-departmental forum for discussing important incidents and risks. As noted in the previous subsection, it prepares annually a risk management report discussing key risks facing the Fund and informally briefs the Board on risk management issues. In June 2011, the Executive Board discussed the 2011 Report on Risk Management. Noting a shift in the IMF's risk profile against the backdrop of a multispeed global recovery, Executive Directors broadly concurred with the assessment of the main risks presented in the report and the proposed mitigation measures. They observed, however, that recent events had focused attention on the IMF, increasing reputational risks, and expressed interest in reviewing and discussing the findings of an external panel on risk management that had been convened.

In December 2010 a high-level external panel had been appointed to undertake an independent and comprehensive review of the IMF's risk management framework. The panel was chaired by Guillermo Ortiz and included as members Jacob A. Frenkel, Malcolm D. Knight, and Thomas O'Neill. The panel submitted its report to the Managing Director in November 2011; the report was also shared with the Executive Board. In accordance with its terms of reference the panel assessed all aspects of the framework - the processes used to identify, evaluate, and mitigate potential risks to the Fund and its operations-recognizing the Fund's unique role in the international financial system, particularly its surveillance activities and responsibilities in crisis lending. An informal briefing of Executive Directors was held 
As of April 30, 2012, the IMF had 2,007 professional and managerial staff and 468 staff at the support level. A list of the Fund's senior officers and the IMF's organization chart can be found on pages 67 and 68, respectively.

The IMF makes every effort to ensure that staff diversity reflects the institution's membership and recruits actively from all over the world (Web Tables 5.1-5.3 show the distribution of the staff by nationality, gender, and country type). ${ }^{69}$ Of the 188 member countries at end-April 2012, 156 were represented on the staff. The Fund made progress in hiring diverse staff during the year, but supply constraints and competition remain challenges: 41 percent of new staff came from underrepresented regions and 44 percent were female. The Fund's Economist Program continued to provide particularly strong diversity results: about 70 percent of the FY2012 cohort came from underrepresented regions, and 55 percent were women. Finally, policy measures introduced in 2011 resulted in the hiring of an additional four staff from East Asia and the Middle East. After meeting the original benchmarks to increase the share of women at the managerial level, the Fund revised the benchmarks in 2011 and added a recruitment benchmark to advance progress toward improved representation of women at the professional and senior levels. Regarding the regional diversity benchmarks, the target for professional and managerial staff from transition countries was met in 2011, and work continues toward meeting the benchmarks for other underrepresented regions.

\section{Management salary structure}

Management remuneration is reviewed periodically by the Executive Board; the Managing Director's salary is approved by the Board of Governors. Annual adjustments are made on the basis of the Washington, D.C., consumer price index. Reflecting the responsibilities of each management position, as of July 1, 2011, the salary structure for management was as follows:

Managing Director

US\$467,940

First Deputy Managing Director

US\$406,900

Deputy Managing Directors

US $\$ 387,530$

The remuneration of Executive Directors was US\$244,350, and the remuneration of Alternate Executive Directors was US $\$ 211,370$. The average salary in FY2012 for IMF senior officers (see page 67) was US\$312,934. Web Table 5.4 provides the salary scale for the IMF staff.

Human resources reforms

Staff survey

Early in 2012, IMF management adopted an action plan to address the challenges identified in a staff survey conducted the previous year. Nine projects with Fund-wide reach were initiated, tackling areas such as career development, performance management, leadership, and accountability. Policy design proposals were completed by the end of April 2012 and will move toward full implementation in FY2013. The next staff survey will be conducted in late 2013.

\section{Promotion reform, compensation, and benefits}

Reforms were introduced in 2011 aimed at building promotion decisions around a structured talent review process, supported by comprehensive competency frameworks and explicit limits on the number of promotion slots. A thorough comparator-based review of staff compensation was also conducted, and significant progress was made in implementing previously approved reforms to the staff retirement plan. A task force review of the 2008 Medical Benefits Plan reforms found that the reform objectives had been achieved.

\section{Modernizing human resources service delivery}

The Fund's Human Resources Department achieved efficiency savings during the year and progressed with the streamlining and automation of its activities. Areas in which specific streamlining was achieved include leave processing and administration, overseas benefits, and performance monitoring for fixed-term staff.

Board review of 2010 Diversity Annual Report

Each year, the IMF's Diversity Advisor prepares a report that provides an accounting of the institution's efforts to promote a more diverse working environment and conditions. The report is prepared in consultation with the Fund's Diversity Council, a Fund-wide representative body that provides guidance to IMF management, department heads, and departmental Diversity Reference Groups; is presented to the Executive Board; and is published on the Fund's external website. ${ }^{70}$

In May 2011, the Executive Board discussed the 2010 Diversity Annual Report. ${ }^{71}$ Executive Directors recognized the value of diversity in improving institutional quality and performance. They welcomed the important progress made in recent years in this area: in particular, building on the diversity infrastructure put in place over previous years, the share of staff from underrepresented regions had increased modestly and that of female staff had increased further in 2010, and several new initiatives had been launched to support sustained progress in subsequent years.

Executive Directors highlighted the important challenges that lay ahead in order to achieve staff diversity that adequately reflected the Fund's membership. They took the opportunity to provide IMF management with broad guidance for the organization and appointment of Fund staff, while supporting the report's recommendations. They encouraged management and staff to step up the momentum and press ahead vigorously in implementing the Fund's diversity agenda. 
Executive Directors welcomed the further increase in the share of professional staff from developing and transition countries to near 45 percent. They noted, however, that the shares of nationals from the four underrepresented regions (Africa, East Asia, the Middle East, and transition countries) remained low, including at the senior level. They supported policy measures that had recently been adopted and called for stronger efforts to raise the share of nationals from these regions, especially for the Middle East region, whose share had declined over the preceding decade.

Executive Directors considered the value of greater diversity of experience and expertise among staff in fostering an effective workforce, noting also the conclusions of the IEO evaluation of IMF performance in the run-up to the financial and economic crisis. They recommended taking into account educational, professional, linguistic, and other dimensions of diversity in recruitment and career development.

Executive Directors commended the achievement of the 20 percent benchmark for the representation of women among senior staff but noted that the Fund lagged behind most comparator international institutions in this regard. They saw a need to further improve gender diversity in core functions, such as senior and economist positions. In this regard, they encouraged the ongoing IMF initiative to reset the benchmark for women among senior staff at an appropriately ambitious level and pointed to the need for supportive working conditions.

Executive Directors supported the report's additional recommendations for further action. They stressed that sustained rapid progress toward the Fund's diversity goals required continuing strong leadership from management and close monitoring and accountability for results of managers at all levels. They called for a special effort to promote diversity among the Fund's senior personnel managers. They welcomed the diversity strategy's emphasis on training and educating staff at all levels about the business case for diversity and adapting personnel management practices to align with the Fund's diversity objectives.

\section{Management changes}

In May 2011, former Managing Director Dominique Strauss-Kahn informed the Executive Board of his intention to resign as Managing Director, with immediate effect. ${ }^{72}$ Upon the Managing Director's resignation, First Deputy Managing Director John Lipsky - who had announced that he would not seek to extend his term as First Deputy Managing Director when it expired (see Box 5.2)—took over as Acting Managing Director. The Executive Board immediately initiated the selection process for the next Managing Director, ${ }^{73}$ adopting a procedure that allowed the selection to take place in an open, merit-based, and transparent manner. Nominees were evaluated against a candidate profile that set forth the qualifications expected, to establish a short list of nominees, without geographical preferences.
Short-listed candidates were then interviewed by the Executive Board, after which the Board met to discuss their strengths, with the objective of selecting the new Managing Director by consensus, as had been the case in previous selection rounds.

In late June, the Board selected Christine Lagarde to serve as IMF Managing Director and Chairman of the Executive Board for a five-year term starting the following month. ${ }^{74} \mathrm{Mme}$. Lagarde is the first woman named to the top IMF post since the institution's inception in 1944.

A national of France, Mme. Lagarde had been the Minister of Finance of France since June 2007. Prior to that, she had served as France's Minister for Foreign Trade for two years. She also had an extensive and noteworthy career as an antitrust and labor lawyer, serving as a partner with the international law firm of Baker \& McKenzie, where the partnership elected her as chairman in October 1999. She held the top post at the firm until June 2005, when she was named to her initial ministerial post in France. She holds degrees from the Institute of Political Studies and from the Law School of University Paris X.

Shortly after beginning her term as Managing Director, Mme. Lagarde proposed the appointment of David Lipton to the position of First Deputy Managing Director, as well as the appointment of Special Advisor to the Managing Director Min Zhu to the position of Deputy Managing Director. ${ }^{75} \mathrm{Mr}$. Lipton, a U.S. national, was at the time the Special Assistant to the President and Senior Director for International Economic Affairs at the U.S. National Economic Council and U.S. National Security Council at the White House. Before taking that job, he had been Managing Director and Head of Global Country Risk Management at Citi and Managing Director of Moore Capital Strategy Group at Moore Capital Management. He had also held senior positions at the U.S. Treasury Department, and served as an economic advisor to the governments of Poland, Russia, and Slovenia during their transitions. After graduating from Harvard University in 1982, where he earned his master's degree and doctorate in economics, Mr. Lipton had served on the staff of the IMF for eight years, working on economic stabilization issues in emerging market economies and lowincome countries.

Mr. Zhu joined the IMF from the People's Bank of China in 2010, where, as Deputy Governor, he was responsible for international affairs, policy research, and credit information. Prior to his service at China's central bank, he held various positions at the Bank of China, where he served as Group Executive Vice President, responsible for finance and treasury, risk management, internal control, legal and compliance, and strategy and research. Mr. Zhu also worked at the World Bank for six years and taught economics at both Johns Hopkins University and Fudan University. 
Box 5.2

Farewell to John Lipsky

After a distinguished five-year term as the First Deputy Managing Director, John Lipsky left the IMF in November 2011, having remained for three additional months as a Special Advisor to the Managing Director. In a farewell reception at IMF headquarters, Executive Directors and IMF management and staff gathered to pay tribute to Mr. Lipsky and his important contributions to the IMF.

Addressing the gathering, Managing Director Christine Lagarde noted the many things at the IMF that "would not have existed without John Lipsky," singling out for particular mention the Early Warning Exercise, the Fund's close relationship with the Financial Stability Board, its close collaboration with the Group of Twenty, and in particular its participation in that organization's Mutual Assessment Process. Executive Board Dean A. Shakour Shaalan offered reasons Mr. Lipsky would be remembered "with great fondness" and drew attention in particular to his service as Acting Managing Director, observing that his leadership and stewardship of the institution had seen it through a very difficult time. Appearing by video, former Managing Director Rodrigo de Rato called hiring Mr. Lipsky "one of the best decisions I made" during his time at the Fund, and Staff Association President Susan George recounted particular occasions on which Mr. Lipsky had come to the support of staff. The Staff Association gave Mr. Lipsky a certificate for a donation in his name to the Staff Compassionate Fund, and the Managing Director presented Mr. Lipsky and his wife with flowers, as well as a commemorative photo album and book of Mr. Lipsky's speeches during his time as First Deputy Managing Director.

Mr. Lipsky recalled walking into the IMF for the very first time in 1973 and his service in the Western Hemisphere and Exchange and Trade Relations (forerunner to the current Strategy, Policy, and Review) Departments and as Resident Representative in Chile. He termed his time as First Deputy Managing Director "a fantastic experience," praising the IMF staff during that time as the most talented group that had ever served the institution and singling out members of his personal staff, as well as his former and current management colleagues, for particular gratitude.

\section{ACCOUNTABILITY}

\section{Transparency}

The IMF's transparency policy, enacted in 1999 and most recently revised in March 2010, states that "recognizing the importance of transparency, the Fund will strive to disclose documents and information on a timely basis unless strong and specific reasons argue against such disclosure." This principle, according to the policy, "respects, and will be applied to ensure, the voluntary nature of publication of documents that pertain to member countries."76 The Executive Board receives annual updates on the implementation of the Fund's transparency policy; these reports are part of the information the IMF makes public as part of its efforts in the area of transparency. The 2011 update is available on the IMF's website. ${ }^{77}$

\section{Independent Evaluation Office}

The Independent Evaluation Office, established in 2001, evaluates IMF policies and activities with the goal of increasing the
Fund's transparency and accountability, strengthening its learning culture, and supporting the Executive Board's institutional governance and oversight responsibilities. Under its terms of reference, the IEO is fully independent of Fund management and operates at arm's length from the Executive Board, to which it reports its findings.

Ongoing IEO evaluations include "International Reserves: IMF Advice and Country Perspectives," "The Role of the IMF as Trusted Adviser," and "Learning from Experience at the IMF: An IEO Assessment of Self-Evaluation Systems.” Full texts of completed evaluations, information on those that are in progress, issues papers, IEO Annual Reports, and other documentation are available on the IEO website. ${ }^{78}$

The IEO celebrated its first decade with a conference at IMF headquarters in December 2011. The conference was attended by Executive Directors, current and former management, senior staff, external stakeholders, and current and past IEO evaluation teams. Box 5.3 gives highlights of the conference. 
Box 5.3

The Independent Evaluation Office's tenth anniversary conference

In his opening remarks at the office's tenth anniversary conference, "Ten Years of Independent Evaluation at the IMF: What Does It Add Up To?" Independent Evaluation Office (IEO) Director Moises Schwartz observed that the IEO was created to strengthen learning and accountability at the IMF and to enhance understanding among external stakeholders of how the institution works. These goals have formed the basis of IEO evaluations. Addressing the conference, Managing Director Christine Lagarde urged the IEO to "continue to produce honest, fair, and demanding analysis." She observed that the IEO brings "ruthless truth-telling to an organization that tells the truth," emphasizing the IMF's reliance on "honesty and credibility." The Chairman of the Executive Board's Evaluation Committee, Executive Director Moeketsi Majoro, pointed to the "commendable contribution that the IEO is making in helping the Fund deliver its mandate more effectively," adding that "as a watchdog, the IEO has to tell it like it is," bringing out "both the successes and the shortcomings." He further observed that "for the IMF to remain relevant and thrive, learning better and faster is critically important . . . it is those most responsive to change [who survive]."

The conference offered an opportunity to consider recurring themes in IEO evaluations. Mr. Schwartz highlighted the following:

Executive Board reviews of IEO reports and recommendations

As noted previously, although the IEO operates at arm's length from the Executive Board, it does report its findings to the Board, which reviews the findings. In May 2011, the IEO completed and published its evaluation of the relevance and utilization of research at the IMF, which was discussed by the Executive Board the following month. The full text of the evaluation, including the Summing Up of the Executive Board discussion pertaining to it, is available on the IEO's website.

Implementation of Board-endorsed IEO recommendations

Soon after each Executive Board discussion of an IEO evaluation report, IMF management presents to the Board a forwardlooking implementation plan for those IEO recommendations that the Board endorses. The implementation plan is part of a framework, established following an external evaluation of the IEO, that seeks to ensure a more systematic follow-up and monitoring of the implementation of Board-endorsed IEO recommendations. That framework includes the Periodic Monitoring Report, established in 2007. Each Periodic Monitoring Report focuses on how the implementation of recent management implementation plans has advanced and whether outstanding recommendations from the previous report have been implemented. -the need to strengthen IMF governance and clarify roles and responsibilities - from the IMFC and the Board to management and senior staff;

-the centrality of greater evenhandedness across the membership in the application of policies and framing of advice;

- the importance of creating incentives to encourage alternative views and support staff in raising difficult issues with country authorities, even in the largest countries; and

- the imperative to better integrate analytical and operational work across departments-promoting cooperation and reducing turf battles and silo behavior.

Participants congratulated the IEO on its work, underscoring the IEO's independence and the quality of its evaluation reports as key strengths. They saw room for improvement in areas such as dissemination and follow-up on recommendations. In particular, many reiterated weaknesses in the IMF's framework for implementation and monitoring of follow-up on Boardendorsed IEO recommendations.

In September 2011, the Executive Board reviewed the Fourth Periodic Monitoring Report, ${ }^{79}$ which examines the implementation status of the management information plan pertaining to recommendations from the IEO's evaluation of IMF involvement in international trade policy issues. It also provides an update on progress in regard to improving the Monitoring of Fund Arrangements database and staff mobility - issues highlighted by the Executive Board's Evaluation Committee from the previous Periodic Monitoring Report. The Board supported the report's conclusion that all key performance benchmarks related to the trade management information plan either had been met or were on track for timely completion. No new remedial actions were proposed, and there were no outstanding performance benchmarks to be reviewed in the next Periodic Monitoring Report, although it would provide further updates as necessary on broader issues raised in the context of the Fourth Report.

\section{Ethics framework for staff, management, and the Executive Board}

The IMF's ethics framework includes a comprehensive set of rules and procedures for disciplinary action, supported by a robust infrastructure that includes the independent Ethics Advisor, an independent Ombudsperson, and the Integrity Hotline, which enables staff and the general public to report misuse of IMF resources or misconduct by staff or vendors securely and anonymously. 
In May 2011, the IMF issued revised standards of conduct for staff, ${ }^{80}$ bringing to fruition more than two years of work on strengthening the institution's ethical framework. The enhanced standards of conduct introduced new reporting requirements in regard to close personal relationships in the workplace and updated the institution's policies on harassment and discrimination. They also reinforced protection against retaliation for staff who report suspected misconduct, while clarifying procedures for conducting and overseeing investigations of such misconduct. The work on updating the standards involved broad collaboration and consultation across the institution. The Fund also benchmarked its policies against those of comparator institutions and reviewed best practices in a cross-section of other organizations.

Executive Directors have also adopted a Code of Conduct, ${ }^{81}$ which is intended to provide guidance on ethical standards in connection with, or having a bearing on, their status and responsibilities in the Fund. An Ethics Committee of the Executive Board considers matters relating to the Code of Conduct. In addition, the Committee gives guidance to Executive Directors, upon request, on ethical aspects of conduct of their alternates, advisors, and assistants.

\section{Engagement with external stakeholders}

Outreach

The IMF's objective in engaging with civil society organizations (CSOs) and youth leaders, trade and labor unions, parliamentarians, academics, and think tanks is twofold: first, to listen to external voices to better understand their concerns and perspectives, with the aim of improving the relevance and quality of Fund policy advice; and second, to improve the outside world's understanding of IMF objectives and operations. New tools are increasingly being used in the Fund's outreach, including social media (see Box 5.4), videos, and podcasts.

Box 5.4

IMF launches Arabic blog

As part of efforts to increase outreach in the Middle East, the IMF launched its Arabic-language blog, The Economic Window (النافذة الاقتصادبة), in October 2011. a The blog complements the IMF's English-language blog, iMFdirect-the Fund's global economy forum — and the Spanish-language blog, Diálogo a Fondo; the IMF also has a specialized Public Financial Management blog. The new Arabic blog aims to encourage interactive debate and offer analysis and potential solutions on economic issues in the Middle East and North Africa, while providing Arabic commen-

a The blog is available at http://blog-montada.imf.org/

\section{Outreach by IMF management}

As the importance of the IMF's outreach efforts has grown in the face of the crisis and aftermath, the management team has played an increasingly important role in recent years in the IMF's outreach efforts. In addition to the more specific outreach goals outlined below, outreach by management and senior IMF staff provides an opportunity, more broadly, to articulate the organization's strategic vision and the key policy priorities for the membership at large; to marshal support for policymakers for difficult national reforms that carry both domestic and global benefits; to learn more about issues affecting key stakeholders in member countries, including nontraditional constituents, with the aim of strengthening Fund analysis and policy advice; and to reinforce the Fund's commitment to providing needed support to members, particularly those most affected by the crisis.

The Managing Director traveled to all five regions during FY2012, meeting with heads of state and other key stakeholders in member countries, making concerted efforts to engage with media, labor, CSOs, parliamentarians, and business groups. Likewise, the First Deputy Managing Director and Deputy Managing Directors traveled extensively during the year and took advantage of numerous opportunities to further the IMF's outreach objectives.

Engagement with labor groups

IMF cooperation with the International Labour Organization (ILO) deepened in FY2012 in the face of the ongoing crisis in Europe. In the joint Social Protection Floor Initiative, currently being piloted in El Salvador, Mozambique, and Vietnam, the ILO determines what would be needed beyond existing social protection mechanisms to establish a basic social protection floor and estimates the cost of a basic set of social transfers; the IMF then assesses the scope for implementing the necessary benefits package in a fiscally sustain- taries and research on global topics. In its first seven months, the blog established a significant readership and posted more than 60 articles, including three blog posts by the Managing Director and four by Deputy Managing Director Nemat Shafik. As of the end of FY2012, it had built up a readership in 52 countries, including Algeria, Egypt, Jordan, Kuwait, Libya, Oman, Saudi Arabia, Tunisia, and the United Arab Emirates. It had been well received in the Middle East and North Africa, and the content had been reproduced by leading Arab blogs and news sites. 
able way, and options are presented to country authorities for decision. IMF-ILO collaboration on labor market and employment issues focuses on policies to promote employment-creating growth, with Fund work focusing primarily on the macroeconomic policy dimension, while the ILO addresses labor market institutional issues. The collaboration reflects the rising importance of labor market issues in Fund advice, especially in program countries and countries in the Middle East and North Africa, where youth unemployment has proven to be a critical issue affecting macroeconomic stability. The social dialogue element of the two organizations' collaboration gained new momentum in FY2012 with preliminary meetings for previously agreed-upon consultations among authorities, unions, and employers in Bulgaria, the Dominican Republic, and Zambia. Formal dialogues were expected to begin in FY2013.

Interaction with labor unions has become an integral element of IMF outreach to nongovernmental stakeholders, and contact with unions in Europe took on increasing importance during FY2012 as the European crisis became more severe. Meetings with national trade unions now take place during the majority of Article IV missions or staff visits, and many resident representatives maintain regular contacts with unions. In addition, IMF management and departments are in regular contact with representatives of the international trade union movement, often under the umbrella of the International Trade Union Confederation, and also in the context of the IMF's relationship with the ILO.

Engagement with civil society organizations

The IMF has engaged intensively with CSOs—-such as nongovernmental organizations, academic institutions and groups, and think tanks - on policy issues for the past decade, with a continuing emphasis on low-income countries. Highlights of this engagement in FY2012 were two conferences, "Management of Natural Resources in Sub-Saharan Africa," cohosted with the government of the Democratic Republic of the Congo in March 2012, and "The East African Community after 10 Years: Deepening EAC Integration," cohosted with the Secretariat of the East African Community the previous month.

Meetings and seminars with CSOs have proven to be excellent avenues for the IMF not only to provide information, but also to listen directly to CSOs' views and voices. Since 2009, the Fund has also solicited CSO views more systematically on specific issues-for example, natural resources taxation and wealth management, the Triennial Surveillance Review (see Chapter 3), and the review of conditionality-through public online consultations.

The CSO Fellowship Program for the 2011 Annual and 2012 Spring Meetings provided an alternative platform for a combined total of 41 leaders from civil society and youth organizations to discuss and enhance the Fund's policy agenda through seminars, face-to-face consultations, and bilateral meetings with IMF management, Executive Directors, and directors and staff from various IMF departments. Similarly, as part of its efforts to foster two-way interaction with stakeholders at the country level, in FY2012 the IMF launched its Academic Fellowship Program, which brings academics from low- and middle-income countries to the IMF's Annual and Spring Meetings, where they participate actively in official events and interact with staff at all levels of the institution. A total of 15 academics from all regions were sponsored during the year.

In addition, the Fund has also broadened and intensified its dialogue and interactions with think tanks and academics around the world and engages them regularly in joint public events and in private exchanges of ideas and views.

\section{Engagement with legislators}

IMF outreach to legislators is aimed at listening to their views and concerns about the Fund's policy advice to countries, and IMF country teams meet with legislators on a regular basis to discuss country-specific issues. During FY2012, the Fund organized, in collaboration with the Parliamentary Network, several events that were particularly geared toward legislators. A workshop held at the 2011 Annual Meetings brought together 24 legislators from 19 countries to discuss the impact of global financial crisis on developing countries and offered legislators an opportunity to provide their views and perspectives on a range of issues. Another workshop during the 2012 Spring Meetings focused on the continued challenges facing developing countries in attempting to deal effectively with the crisis and on issues such as inclusive growth and IMF governance reforms.

In March 2012, more than 120 parliamentarians from 40 African countries gathered in Kigali, Rwanda, for a two-day conference, organized by the Parliamentary Network in collaboration with the IMF and World Bank, on building the private sector's role as an engine of growth in Africa. The conference was hosted by the Rwandan government and included an address by President Paul Kagame.

\section{Charitable activities}

The IMF's Civic and Community Relations Program builds on the institution's overarching objective to foster policies that boost economic growth and improve the well-being of people in its 188 member countries. It aims to help the community in the greater Washington, D.C., area (the IMF's host city), as well as charities working in developing countries, through staff donations that are partially matched by the institution, volunteering activities, and community initiatives. Fund grants and donations have totaled more than US\$18 million since 1994 when the program was created and reached nearly US $\$ 800,000$ in FY2012. That total included just over US\$325,000 in matching funds for the Helping Hands program, an annual employee giving campaign that raised more than US\$650,000 from staff and retirees in its fall 2011 campaign, and nearly US $\$ 70,000$ in matching contributions for staff-initiated humanitarian relief drives to assist victims of natural disasters in developing countries. The Fund's Civic Program Advisory Committee, a twelve-member

\section{CInternational Monetary Fund. Not for Redistribution}


committee of volunteers representing staff, retirees, and spouses, leads Fund efforts to support, through monetary grants (totaling nearly US $\$ 400,000$ in FY2012), nonprofit organizations in Washington, D.C., and in developing countries.

\section{Regional Economic Outlook reports}

The IMF publishes, as part of its World Economic and Financial Surveys, Regional Economic Outlook reports (REOs), providing more-detailed analysis of economic developments and key policy issues for major world regions. Publication of the REOs is typically coordinated with extensive outreach events in each region. Press releases summarizing REO findings can be found on the IMF's website, along with the full text of the REOs themselves, as well as transcripts and webcasts of press conferences held upon publication. ${ }^{82}$

\section{IMF regional offices}

\section{Office for Asia and the Pacific}

As the Fund's window to the Asia and Pacific region, the importance of which is growing in the global economy, the Office for Asia and the Pacific (OAP) assists in monitoring economic and financial developments to help bring a more regionally focused perspective to the Fund's surveillance. It seeks both to enhance the understanding of the Fund and its policies in the region and to keep the Fund informed of regional perspectives on key issues. In this capacity, OAP has increased its bilateral and regional surveillance with an expanding role in Mongolia, active participation on Japan work, increased regional surveillance with forums in Asia including ASEAN+3, and stepped-up outreach in support of the 2012 Annual

\section{Box 5.5}

\section{Conference on public health care reform in Asia}

Health care reform is an important fiscal issue worldwide, particularly in advanced economies, where public health spending is projected to rise by an average of 3 percentage points of GDP over the next 20 years. Senior government officials and leading academics from 11 countries discussed public health reform in Asia at an October 2011 conference in Tokyo, jointly organized by the IMF's Fiscal Affairs Department and Office for Asia and the Pacific and supported by the Japanese government. The one-day conference was part of the IMF's efforts to continue its dialogue with country authorities and the public on the key fiscal challenges facing member countries.

In opening the conference, IMF Deputy Managing Director Min Zhu underscored that successful fiscal consolidation efforts in advanced economies would require containing the growth of agerelated public spending, including on health. Effective policy tools exist to contain the grown of public health care spending, he observed, including budget caps, judicious use of competition to foster efficiency, payment systems that reduce the use of fee-for-service arrangements,
Meetings in Tokyo. OAP also continues to organize conferences and events that offer a forum for discussion of current topics central to the IMF's work (Box 5.5 gives one example), as well as promoting capacity building in the region through the Japan-IMF scholarship program and macroeconomic seminars.

\section{Offices in Europe}

The IMF's Offices in Europe (EUO) represent the Fund in the region, advising management and departments as needed, supporting the Fund's operations in Europe, and providing a conduit for European views on issues of interest to the Fund. European-based institutions, including the Organisation for Economic Co-operation and Development (OECD), EU, FSB, and BIS, are playing a crucial role in dealing with the economic and financial crisis. Strengthening the IMF's coordination with these institutions has thus been paramount.

EUO's activities focus primarily on four areas. First, EUO contributes to the Fund's multilateral and regional surveillance by representing the IMF in various institutions and by reporting on the views and activities of European-based international organizations, think tanks, and prominent experts, and participating in Fund consultations with EU institutions. Second, EUO represents the Fund in the day-to-day activities of the OECD's Development Assistance Committee and has close working relationships with bilateral and multilateral development agencies in Europe. Third, EUO conducts extensive outreach to better inform the policy debate and disseminate the Fund's views on key policy issues in Europe. Fourth, EUO works with the Fund's Human Resources Department to help fulfill the Fund's recruitment objectives. and greater reliance on private financing, including through greater use of private insurance.

As $\mathrm{Mr}$. Zhu noted, in emerging economies, there is more fiscal space to increase spending to expand coverage of health services, especially in emerging Asia, where health outcomes are good relative to spending. Challenges include the need to provide universal coverage to the population with a fiscally sustainable package of services. The goal would be to lower high out-of-pocket expenditures to improve financial protection. Assessing the cost-effectiveness of health interventions is also a priority for the region.

Asia offers a number of success stories that can be drawn upon in forging reform strategies. These include Japan's success in containing cost growth, as well as Thailand's achievement of universal health coverage in spite of a high degree of labor market informality. The appropriate mix of reforms to draw from the region's success stories will depend on country circumstances. 


\section{EXECUTIVE DIRECTORS AND ALTERNATES}

as of April 30, $2012^{1}$

\section{APPOINTED}

\begin{tabular}{ll}
\hline $\begin{array}{l}\text { Meg Lundsager } \\
\text { Vacant }\end{array}$ & United States \\
\hline $\begin{array}{l}\text { Mitsuhiro Furusawa } \\
\text { Tomoyuki Shimoda }\end{array}$ & Japan \\
\hline $\begin{array}{l}\text { Hubert Temmeyer } \\
\text { Steffen Meyer }\end{array}$ & Germany \\
\hline $\begin{array}{l}\text { Ambroise Fayolle } \\
\text { Alice Terracol }\end{array}$ & France \\
\hline $\begin{array}{l}\text { Alexander Gibbs } \\
\text { Robert Elder }\end{array}$ & United Kingdom \\
\hline
\end{tabular}

\section{ELECTED}

\begin{tabular}{|c|c|}
\hline $\begin{array}{l}\text { Willy Kiekens } \\
\text { (Belgium) } \\
\text { Johann Prader } \\
\text { (Austria) }\end{array}$ & $\begin{array}{l}\text { Austria, Belarus, Belgium, Czech } \\
\text { Republic, Hungary, Kosovo, Luxem- } \\
\text { bourg, Slovak Republic, Slovenia, } \\
\text { Turkey }\end{array}$ \\
\hline $\begin{array}{l}\text { Carlos Pérez-Verdía } \\
\text { (Mexico) } \\
\text { José Rojas Ramirez } \\
\text { (Venezuela) }\end{array}$ & $\begin{array}{l}\text { Costa Rica, El Salvador, Guatemala, } \\
\text { Honduras, Mexico, Nicaragua, Spain, } \\
\text { Venezuela }\end{array}$ \\
\hline $\begin{array}{l}\text { Menno Snel } \\
\text { (Netherlands) } \\
\text { Yuriy G. Yakusha } \\
\text { (Ukraine) }\end{array}$ & $\begin{array}{l}\text { Armenia, Bosnia and Herzegovina, } \\
\text { Bulgaria, Croatia, Cyprus, Georgia, } \\
\text { Israel, former Yugoslav Republic of } \\
\text { Macedonia, Moldova, Montenegro, } \\
\text { Netherlands, Romania, Ukraine }\end{array}$ \\
\hline $\begin{array}{l}\text { Arrigo Sadun } \\
\text { (Italy) } \\
\text { Thanos Catsambas } \\
\text { (Greece) }\end{array}$ & $\begin{array}{l}\text { Albania, Greece, Italy, Malta, Portugal, } \\
\text { San Marino, Timor-Leste }\end{array}$ \\
\hline
\end{tabular}

\begin{tabular}{|c|c|}
\hline $\begin{array}{l}\text { Der Jiun Chia } \\
\text { (Singapore) } \\
\text { Aida Budiman } \\
\text { (Indonesia) }\end{array}$ & $\begin{array}{l}\text { Brunei Darussalam, Cambodia, Fiji, } \\
\text { Indonesia, Lao P.D.R., Malaysia, } \\
\text { Myanmar, Nepal, Philippines, } \\
\text { Singapore, Thailand, Tonga, Vietnam }\end{array}$ \\
\hline $\begin{array}{l}\text { Tao Zhang } \\
\text { (China) } \\
\text { Ping Sun } \\
\text { (China) }\end{array}$ & China \\
\hline $\begin{array}{l}\text { Christopher Legg } \\
\text { (Australia) } \\
\text { Hoseung Lee } \\
\text { (Korea) }\end{array}$ & $\begin{array}{l}\text { Australia, Kiribati, Korea, Marshall } \\
\text { Islands, Micronesia, Mongolia, New } \\
\text { Zealand, Palau, Papua New Guinea, } \\
\text { Samoa, Seychelles, Solomon Islands, } \\
\text { Tuvalu, Uzbekistan, Vanuatu }\end{array}$ \\
\hline $\begin{array}{l}\text { Thomas Hockin } \\
\text { (Canada) } \\
\text { Mary O'Dea } \\
\text { (Ireland) }\end{array}$ & $\begin{array}{l}\text { Antigua and Barbuda, The Bahamas, } \\
\text { Barbados, Belize, Canada, Dominica, } \\
\text { Grenada, Ireland, Jamaica, St. Kitts and } \\
\text { Nevis, St. Lucia, St. Vincent and the } \\
\text { Grenadines }\end{array}$ \\
\hline
\end{tabular}

$\begin{array}{ll}\begin{array}{l}\text { Benny Andersen } \\ \text { (Denmark) }\end{array} & \text { Denmark, Estonia, Finland, Iceland, } \\ \text { Latvia, Lithuania, Norway, Sweden }\end{array}$
Audun Gronn (Norway)

\begin{tabular}{ll}
\hline $\begin{array}{l}\text { Moeketsi Majoro } \\
\text { (Lesotho) }\end{array}$ & Angola, Botswana, Burundi, Eritrea, \\
Momodou Saho & Ethiopia, The Gambia, Kenya, Lesotho, \\
(The Gambia) & Liberia, Malawi, Mozambique, \\
& Namibia, Nigeria, Sierra Leone, South \\
& Africa, Sudan, Swaziland, Tanzania, \\
& Uganda, Zambia, Zimbabwe \\
\hline A. Shakour Shaalan & Bahrain, Egypt, Iraq, Jordan, Kuwait, \\
(Egypt) & Lebanon, Libya, Maldives, Oman, \\
Sami Geadah & Qatar, Syria, United Arab Emirates, \\
(Lebanon) & Yemen \\
\hline $\begin{array}{l}\text { Arvind Virmani } \\
\text { (India) }\end{array}$ & Bangladesh, Bhutan, India, Sri Lanka \\
P. Nandalal Weerasinghe & \\
(Sri Lanka) & \\
\hline
\end{tabular}

\begin{tabular}{ll}
\hline $\begin{array}{l}\text { Paulo Nogueira Batista, Jr. } \\
\text { (Brazil) }\end{array}$ & $\begin{array}{l}\text { Brazil, Colombia, Dominican Republic, } \\
\text { Ecuador, Guyana, Haiti, Panama, }\end{array}$ \\
$\begin{array}{l}\text { María Angélica Arbeláez } \\
\text { (Colombia) }\end{array}$ & Suriname, Trinidad and Tobago \\
\hline
\end{tabular}

\begin{tabular}{ll}
\hline $\begin{array}{l}\text { Ahmed Alkholifey } \\
\text { (Saudi Arabia) }\end{array}$ & Saudi Arabia \\
$\begin{array}{l}\text { Fahad I. Alshathri } \\
\text { (Saudi Arabia) }\end{array}$ \\
\hline $\begin{array}{l}\text { René Weber } \\
\text { (Switzerland) }\end{array}$ \\
$\begin{array}{l}\text { Katarzyna Zajdel-Kurowska } \\
\text { (Poland) }\end{array}$ & $\begin{array}{l}\text { Azerbaijan, Kazakhstan, Kyrgyz } \\
\text { Republic, Poland, Serbia, Switzerland, }\end{array}$ \\
\hline
\end{tabular}

\begin{tabular}{|c|c|}
\hline $\begin{array}{l}\text { Aleksei V. Mozhin } \\
\text { (Russian Federation) } \\
\text { Andrei Lushin } \\
\text { (Russian Federation) }\end{array}$ & Russian Federation \\
\hline $\begin{array}{l}\text { Jafar Mojarrad } \\
\text { (Islamic Republic of Iran) } \\
\text { Mohammed Daïri } \\
\text { (Morocco) }\end{array}$ & $\begin{array}{l}\text { Afghanistan, Algeria, Ghana, Islamic } \\
\text { Republic of Iran, Morocco, Pakistan, } \\
\text { Tunisia }\end{array}$ \\
\hline $\begin{array}{l}\text { Alfredo Mac Laughlin } \\
\text { (Argentina) } \\
\text { Pablo Garcia-Silva } \\
\text { (Chile) }\end{array}$ & $\begin{array}{l}\text { Argentina, Bolivia, Chile, Paraguay, } \\
\text { Peru, Uruguay }\end{array}$ \\
\hline
\end{tabular}

\begin{tabular}{ll}
\hline Kossi Assimaidou & Benin, Burkina Faso, Cameroon, Cape \\
(Togo) & Verde, Central African Republic, Chad, \\
Nguéto Tiraina Yambaye & Comoros, Democratic Republic of the \\
(Chad) & Congo, Republic of Congo, Côte \\
& d'Ivoire, Djibouti, Equatorial Guinea, \\
& Gabon, Guinea-Bissau, Mali, \\
& Mauritania, Mauritius, Niger, Rwanda, \\
São Tomé and Príncipe, Senegal, Togo
\end{tabular}




\section{SENIOR OFFICERS}

as of April 30, 2012

Olivier J. Blanchard , Economic Counsellor

José Viñals, Financial Counsellor

\section{AREA DEPARTMENTS}

Antoinette Monsio Sayeh

Director, African Department

Anoop Singh

Director, Asia and Pacific Department

Reza Moghadam

Director, European Department

Masood Ahmed

Director, Middle East and Central Asia Department

Nicolas Eyzaguirre

Director, Western Hemisphere Department

$\overline{\text { FUNCTIONAL AND SPECIAL SERVICES }}$ DEPARTMENTS

Gerard T. Rice

Director, External Relations Department

Andrew Tweedie

Director, Finance Department

Carlo Cottarelli

Director, Fiscal Affairs Department

Sharmini A. Coorey

Director, IMF Institute

Sean Hagan

General Counsel and Director, Legal Department

José Viñals

Director, Monetary and Capital Markets Department

Olivier J. Blanchard

Director, Research Department
Adelheid Burgi-Schmelz

Director, Statistics Department

Siddharth Tiwari

Director, Strategy, Policy, and Review Department

\section{INFORMATION AND LIAISON}

Shogo Ishii

Director, Regional Office for Asia and the Pacific

Emmanuel van der Mensbrugghe

Director, Offices in Europe

Elliott C. Harris

Special Representative to the United Nations

\section{SUPPORT SERVICES}

Mark W. Plant

Director, Human Resources Department

Jianhai Lin

Secretary of the Fund, Secretary's Department

Frank Harnischfeger

Director, Technology and General Services Department

Jonathan Palmer

Chief Information Officer, Technology and General Services Department

\section{OFFICES}

Daniel A. Citrin

Director, Office of Budget and Planning

G. Russell Kincaid

Director, Office of Internal Audit and Inspection

J. Roberto Rosales

Director, Office of Technical Assistance Management

Moises J. Schwartz

Director, Independent Evaluation Office 


\section{IMF ORGANIZATION CHART}

as of April 30, 2012
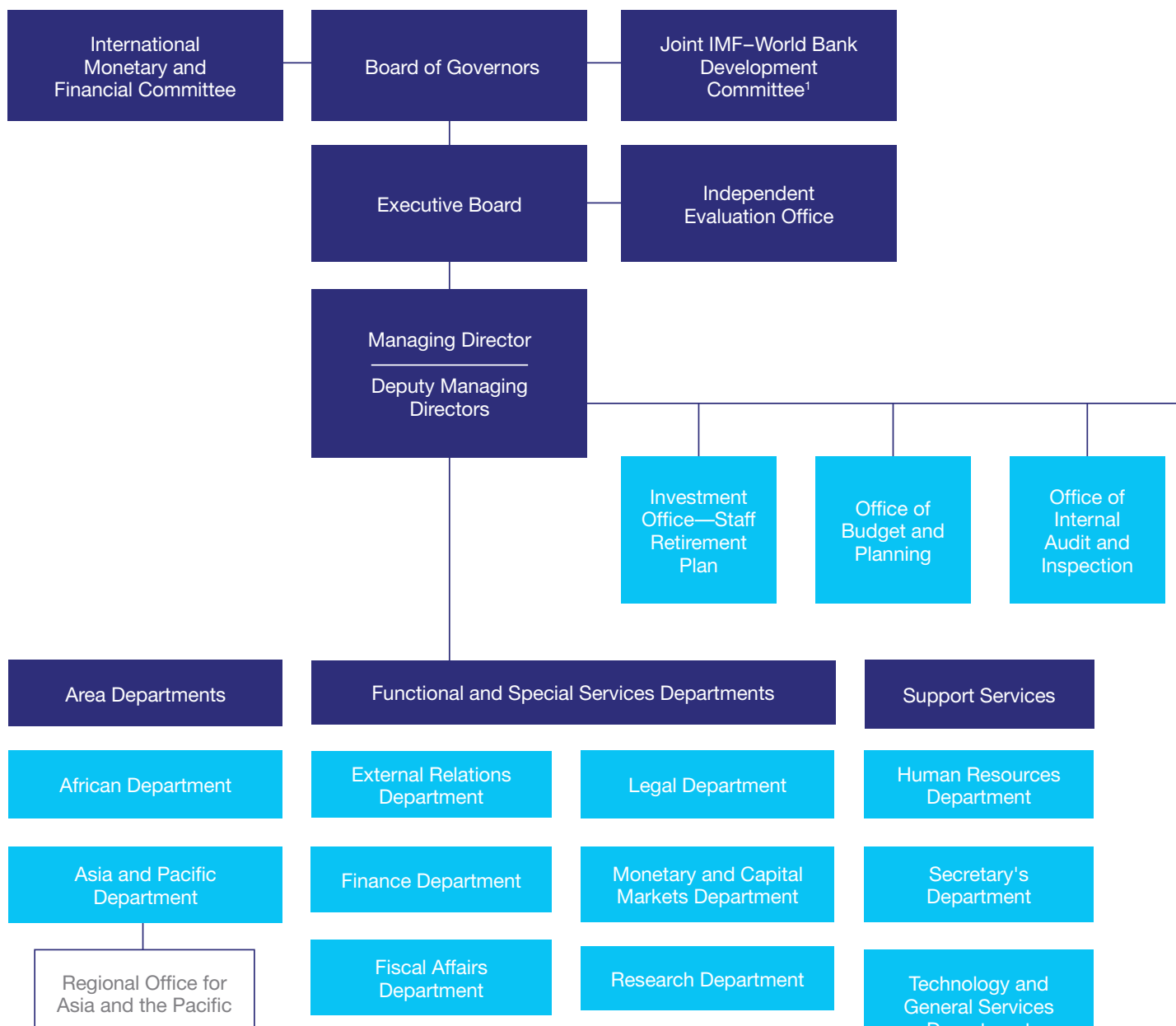

Legal Department

\section{Support Services}

Human Resources Department

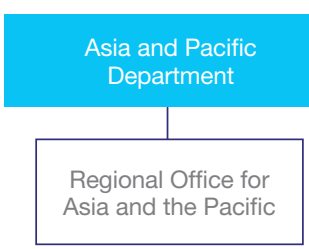

European Department

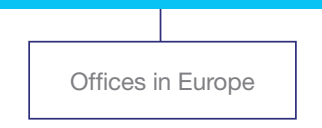

Middle East and Central Asia Department

Western Hemisphere Department

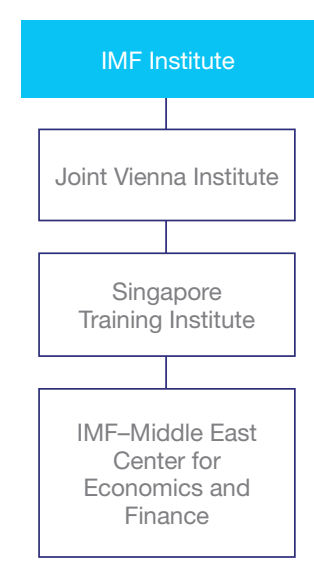

Monetary and Capital Markets Department

Research Department

Statistics Department

Strategy,

Policy, and

Review Department

Fund Office United Nations

\section{Secretary's} Department

Technology and General Services Department 
NOTES

\section{CHAPTER 1}

1 The IMF's financial year (FY) begins on May 1 and ends the following April 30. The 2012 Annual Report covers the period May 1, 2011, through April 30, 2012 (FY2012).

2 This amount was subsequently increased, to US\$456 billion, during the Group of Twenty Leaders' Summit in Los Cabos in June 2012.

3 The IMF's Special Drawing Right (SDR) is an international reserve asset whose value is based on a basket of four key international currencies (see Web Box 3.1), All conversions of SDR amounts to specific currencies are approximate.

\section{CHAPTER 3}

4 See Press Release (PR) No. 12/13, "Statement by IMF Managing Director Christine Lagarde Following Executive Board Discussion on the Adequacy of Fund Resources" (www.imf.org/external/np/sec/pr/2012/pr1213.htm).

5 The Executive Board's discussion on the setting of the margin (that is, the amount in excess of the SDR interest rate) for FY2012 is covered in Chapter 5.

6 There are exceptions; in FCL and PLL arrangements, for example, the full amount of resources committed is available at any time during the period of the arrangements, subject to review requirements inherent in each type of arrangement.

7 This is a gross amount, not netted for cancelled arrangements.

8 The arrangement for Georgia is a blend of an SBA and a Standby Credit Facility.

9 Disbursements under financing arrangements from the General Resources Account are termed "purchases," and repayments are referred to as "repurchases."

10 The IMF uses the same per capita income threshold as is used by the World Bank Group to determine eligibility for International Development Association resources, which is revised annually.

11 Specifically, an income that exceeds twice the International Development Association per capita income threshold.

12 See Public Information Notice (PIN) No. 12/22, "IMF Reviews Eligibility for Using Concessional Financing Resources" (www.imf.org/external/np/sec/pn/2012/pn1222.htm).
13 See PR No. 09/268, "IMF Announces Unprecedented Increase in Financial Support to Low-Income Countries" (www.imf.org/external/np/sec/pr/2009/pr09268.htm).

14 "Windfall" profits from the IMF's gold sales refer to the difference between the profits projected at the time the gold sales were proposed, and the actual profits realized, given that gold prices rose considerably in the interim. See Chapter 5 .

15 See PIN No. 11/152, “The Fund's Financing Role-Reform Proposals on Liquidity and Emergency Assistance and the Review of the Flexible Credit Line and Precautionary Credit Line" (www.imf.org/external/np/sec/pn/2011/pn11152.htm).

16 See PIN No. 12/25, "IMF Executive Board Discusses Amendment to the Extended Fund Facility to Extend the Arrangement Duration at Approval" (www.imf.org/external/np/sec/pn/2012/ pn1225.htm).

17 See PIN No. 11/95, "IMF Executive Board Discusses the Macroeconomic and Operational Challenges in Countries in Fragile Situations" (www.imf.org/external/np/sec/ pn/2011/pn1195.htm). As defined in the staff paper that formed the basis for the Board's discussion, fragility has a number of dimensions, with economic conditions being only one. The paper notes that common characteristics of fragile states are institutions that are seen as being weak and governments that are perceived to lack legitimacy, all of which elevate the risk of violence, and that virtually all existing definitions of fragility incorporate a measure of institutional weakness.

18 Credit tranches refer to the size of a member's purchases (disbursements) in proportion to its quota in the IMF. Disbursements up to 25 percent of a member's quota are disbursements under the first credit tranche and require members to demonstrate reasonable efforts to overcome their balance of payments problems. Disbursements above 25 percent of quota are referred to as upper-credit-tranche drawings; they are made in installments, as the borrower meets certain established performance targets. Such disbursements are normally associated with Stand-By or Extended Arrangements (and also the Flexible Credit Line). Access to IMF resources outside an arrangement is rare and expected to remain so.

19 See PIN No. 11/98, "IMF Executive Board Discusses Systemic Crises, Financial Linkages, and the Role of Global Financial Safety Nets" (www.imf.org/external/np/sec/ pn/2011/pn1198.htm). 
20 A consolidated spillover report was prepared in early FY2013, covering the same five systemic economies as in the FY2012 pilot exercise.

21 See PIN No. 11/130, "IMF Executive Board Reviews Surveillance: Making IMF Surveillance as Interconnected as the Global Economy" (www.imf.org/external/np/sec/pn/2011/ pn11130.htm).

22 See “Managing Director’s Statement on Strengthening Surveillance: 2011 Triennial Surveillance Review” (www.imf.org/ external/np/pp/eng/2011/102711.pdf).

23 These are missions conducted in connection with the Fund's regular Article IV consultations with members; see "Bilateral Surveillance" earlier in the chapter.

24 In its evaluation of IMF performance in the run-up to the financial and economic crisis, available on the IEO's website (www.ieo-imf.org).

25 See PIN No. 11/61, "IMF Executive Board Discusses Monitoring Financial Interconnectedness, Including the Data Template for Global Systemically Important Financial Institutions" (www.imf.org/external/np/sec/pn/2011/pn1161.htm).

26 See PIN No. 11/74, "IMF Executive Board Reviews Efforts in Anti-Money Laundering and Combating the Financing of Terrorism" (www.imf.org/external/np/sec/pn/2011/pn1174.htm).

27 Reports on the Observance of Standards and Codes (see Web Box 4.1) are prepared and published at the request of member countries and summarize the extent to which those countries observe certain internationally recognized standards and codes in 12 areas, including AML/CFT. They are used to help sharpen the institutions' policy discussions with national authorities, and in the private sector (including by rating agencies) for risk assessment.

28 This review took place in March 2011; see Chapter 3 of the IMF's Annual Report 2011: Pursuing Balanced and Equitable Growth (www.imf.org/external/pubs/ft/ar/2011/eng/index.htm).

29 See PIN No. 12/37, "IMF Discusses Work Agenda for Financial Sector Surveillance” (www.imf.org/external/np/sec/ pn/2012/pn1237.htm).

30 See PIN No. 11/118, "IMF Executive Board Discusses Modernizing Fiscal Policy Framework and Public Debt Sustainability Analysis" (www.imf.org/external/np/sec/ pn/2011/pn11118.htm).

31 See PIN No. 11/139, "IMF Executive Board Discusses Managing Global Growth Risks and Commodity Price ShocksVulnerabilities and Policy Challenges for Low-Income Countries" (www.imf.org/external/np/sec/pn/2011/pn11139.htm).

32 See PIN No. 11/143, "IMF Executive Board Discusses the Multilateral Aspects of Policies Affecting Capital Flows" (www.imf.org/external/np/sec/pn/2011/pn11143.htm).
33 See PIN No. 12/42, "IMF Executive Board Discusses Liberalizing Capital Flows and Managing Outflows" (www.imf.org/external/np/sec/pn/2012/pn1242.htm).

34 See PIN No. 11/137, "IMF Executive Board Discusses Criteria for Broadening the SDR Currency Basket" (www.imf.org/external/np/sec/pn/2011/pn11137.htm).

35 Since 2000, the SDR basket has consisted of the four currencies that (1) are issued by Fund members (or monetary unions of Fund members) which are the largest exporters and (2) have been determined by the Fund to be a "freely usable" currency - a currency that is, in fact, widely used to make payments for international transactions and is widely traded in the principal foreign exchange markets. The SDR basket currencies are currently the U.S. dollar, the euro, the pound sterling and the Japanese yen. Considerations relating to the freely usable concept have been taken into account for SDR valuation since the Second Amendment to the Articles of Agreement in 1978, but a formal requirement that currencies in the SDR basket be freely usable was adopted only in 2000 .

\section{CHAPTER 4}

36 The resources of this trust, established to provide debt relief under the HIPC Initiative and to subsidize PRGT lending, consist of grants and deposits pledged from 93 member countries and contributions from the IMF itself.

37 The IMF has also provided SDR 116 million in debt relief to Liberia beyond that provided through the HIPC Initiative, as well as SDR 178 million in debt relief to Haiti through the Post-Catastrophe Debt Relief Trust.

38 See PIN No. 11/151, "IMF Executive Board Discusses the Heavily Indebted Poor Countries (HIPC) Initiative and Multilateral Debt Relief Initiative (MDRI) - Status of Implementation and Proposals for the Future of the HIPC Initiative" (www.imf.org/external/np/sec/pn/2011/pn11151.htm).

39 Chad, Comoros, Côte d'Ivoire, Eritrea, Guinea, Somalia, and Sudan.

40 See PIN No. 12/17, "IMF Executive Board Reviews the Joint IMF-World Bank Debt Sustainability Framework for LowIncome Countries" (www.imf.org/external/np/sec/pn/2012/ pn1217.htm).

41 As noted previously, in May 2012 the IMF Institute was merged into a new Fund department, the Institute for Capacity Development.

42 For more information on the SDDS and GDDS, see "Factsheet: IMF Standards for Data Dissemination" (www.imf.org/ external/np/exr/facts/data.htm), as well as Web Box 4.1.

43 See PR No. 11/423, "The Former Yugoslav Republic of Macedonia Subscribes to the IMF Special Data Dissemination Standard" (www.imf.org/external/np/sec/pr/2011/pr11423.htm), 
and PR No. 12/62, "Mauritius Subscribes to the IMF's Special Data Dissemination Standard" (www.imf.org/external/np/ sec/pr/2012/pr1262.htm).

44 See PR No. 11/242, “The Solomon Islands Begins Participating in the IMF's General Data Dissemination System" (www. imf.org/external/np/sec/pr/2011/pr11242.htm); PR No. $11 / 247$, "The Republic of Guyana Begins Participating in the IMF's General Data Dissemination System" (www.imf .org/ external/np/sec/pr/2011/pr11247.htm); PR No. 11/305, "Burundi Begins Participation in the IMF's General Data Dissemination System" (www.imf.org/external/np/sec/pr/2011/ pr11305.htm); PR No. 11/367, "The Republic of Maldives Begins Participation in the IMF's General Data Dissemination System" (www.imf.org/external/np/sec/pr/2011/pr11367.htm); PR No. 11/441, "Montenegro Begins Participation in the IMF's General Data Dissemination System" (www.imf.org/external/ np/sec/pr/2011/pr11441.htm); PR No. 12/48, "The Republic of Djibouti Begins Participating in the IMF's General Data Dissemination System" (www.imf .org/external/np/sec/pr/2012/ pr1248.htm); and PR No. 12/51, "Papua New Guinea Begins Participation in the IMF's General Data Dissemination System" (www.imf.org/external/np/sec/pr/2012/pr1251.htm).

45 This bulletin board is available via the IMF's website (http:// dsbb.imf.org/Applications/web/gdds/gddscountrylist/).

46 See PIN No. 12/18, "IMF Executive Board Discusses Eighth Review of Data Standards" (www.imf.org/external/np/sec/ pn/2012/pn1218.htm).

47 See PR No. 11/274, "IMF Releases 2011 Financial Access Survey Data” (www.imf.org/external/np/sec/pr/2011/pr11274 .htm). The database is available publicly on the IMF's website (http://fas.imf.org/) and through the IMF's e-Library-Data (http://elibrary-data.imf.org/).

48 See PR No. 11/271, "IMF Expands Foreign Direct Investment Coverage to 84 Economies" (www.imf.org/external/np/sec/ pr/2011/pr11271.htm), and PR No. 11/479, "IMF Releases Results from Its 2010 Coordinated Direct Investment Survey” (www.imf.org/external/np/sec/pr/2011/pr11479.htm). The database is available publicly on the IMF's website (http:// cdis.imf.org) and through the IMF's e-Library-Data (http:// elibrary-data.imf.org/).

49 See PR No. 11/428, "Cross-Border Holdings Increased 7.7 Percent in 2010, Shows IMF Annual Coordinated Portfolio Investment Survey Now Available via New Online Database" (www.imf.org/external/np/sec/pr/2011/pr11428.htm). The new database is available on the IMF's website (http://cpis .imf.org) and through the IMF's eLibrary-Data (http:// elibrary-data.imf.org/).

50 See PR No. 11/161, "IMF and World Bank Co-Host Third Global SDMX Conference to Advance Implementation of Worldwide Standards for Data and Metadata Exchange" (www.imf.org/external/np/sec/pr/2011/pr11161.htm).
51 The website is available at www.principalglobalindicators.org/ default.aspx.

52 See PIN No. 11/72, "IMF Executive Board Reviews Experience with the Fund's Involvement in the G-20 Mutual Assessment Process" (www.imf.org/external/np/sec/pn/2011/ pn1172.htm).

53 See IMF and FSB, "The Financial Crisis and Information Gaps: Implementation Progress Report" (www.financialsta bilityboard.org/publications/r_110715.pdf).

\section{CHAPTER 5}

54 See www.imf.org/external/np/sec/pr/2011/pdfs/quota_tbl.pdf.

55 See PIN No. 12/35, "IMF Executive Board Begins Review of Quota Formula” (www.imf.org/external/np/sec/pn/2012/ pn1235.htm).

56 The current additive quota formula consists of four variables. GDP has the largest weight (50 percent), consisting of a blend of GDP converted at market exchange rates (30 percent) and purchasing-power-parity-based GDP (20 percent). Openness, which measures the sum of current payments and receipts (30 percent); variability of current receipts and net capital flows (15 percent); and official foreign exchange reserves (5 percent) are the remaining variables.

57 A compression factor of 0.95 is applied to the weighted sum of the four variables in the quota formula, which reduces the dispersion in calculated quota shares across members. This has the effect of reducing the share calculated under the formula for the largest members, and raising those for all other countries.

58 Activation requires the consent of NAB participants with an 85 percent majority of total credit arrangements among participants eligible to vote, and the approval of the Executive Board.

59 Individual member countries in the euro area contributed toward this $€ 150$ billion pledge in the following amounts: Austria, $€ 6.1$ billion; Belgium, $€ 10.0$ billion; Cyprus, $€ 0.5$ billion; Finland, $€ 3.8$ billion; France, $€ 31.4$ billion; Germany, $€ 41.5$ billion; Italy, $€ 23.5$ billion; Luxembourg, €2.1 billion; Malta, €0.3 billion; the Netherlands, $€ 13.6$ billion; the Slovak Republic, $€ 1.6$ billion; Slovenia, €0.9 billion; and Spain, €14.9 billion.

60 Norway's April 2012 announcement confirmed a pledge made in December 2011; see PR No. 12/138, "Statement by IMF Managing Director Christine Lagarde on Pledges by Denmark, Norway and Sweden to Increase IMF Resources by over US\$26 Billion" (www.imf.org/external/np/sec/pr/2012/pr12138.htm).

61 See PR No. 12/137, "Statement by IMF Managing Director Christine Lagarde on Japan's \$60 Billion Pledge” (www.imf .org/external/np/sec/pr/2012/pr12137.htm); PR No. 12/138, "Statement by IMF Managing Director Christine Lagarde on Pledges by Denmark, Norway and Sweden to Increase IMF 
Resources by over US\$26 Billion” (www.imf.org/external/np/ sec/pr/2012/pr12138.htm); PR No. 12/141, "Statement by IMF Managing Director Christine Lagarde on Pledge by Poland to Increase IMF Resources by about US $\$ 8$ Billion" (www.imf .org/external/np/sec/pr/2012/pr12141.htm); PR No. 12/142, "Statement by IMF Managing Director Christine Lagarde on Further Pledges by Switzerland and Other Members to Increase IMF Resources by about US\$26 Billion” (www.imf.org/ external/np/sec/pr/2012/pr12142.htm); PR No. 12/146, "Statement by IMF Managing Director Christine Lagarde on Pledges by Australia, Korea, Singapore and the United Kingdom to Increase IMF Resources by about US\$41 Billion” (www.imf.org/external/np/sec/pr/2012/pr12146.htm); PR No. 12/147, "IMF Managing Director Christine Lagarde Welcomes Pledges by Members to Increase Fund Resources by over US $\$ 430$ Billion" (www.imf.org/external/np/sec/ pr/2012/pr12147.htm); and PR No 12/148, "Statement from Indonesia, Malaysia and Thailand" (www.imf.org/ external/np/sec/pr/2012/pr12148.htm). As noted previously, this amount was subsequently increased, to US $\$ 456$ billion, in June 2012.

62 See PR No. 11/485 "IMF Executive Board Adopts New Rule for Basic Rate of Charge on IMF's GRA Lending" (www.imf .org/external/np/sec/pr/2011/pr11485.htm).

63 For an explanation of credit tranches, see note 18.

64 See PIN No. 11/48, "IMF Executive Board Considers Use of Gold Sale Profits” (www.imf.org/external/np/sec/pn/2011/ pn1148.htm)

65 See PR No. 12/56, "IMF Executive Board Approves Distribution of US \$1.1 Billion Gold Sales Profits to Facilitate Contributions to Support Concessional Lending to Low-Income Countries" (www.imf.org/external/np/sec/pr/2012/pr1256.htm).

66 See PIN No. 11/121, "IMF Executive Board Considers Use of Windfall Gold Sale Profits" (www.imf.org/external/np/secl pn/2011/pn11121.htm).

67 The difference between gross and net expenditures relates to receipts, mostly external donor financing for capacitybuilding activities carried out by the IMF.

68 See PR No. 11/292, "IMF Statement on South Sudan” (www .imf.org/external/np/sec/pr/2011/pr11292.htm); PR No. 11/472, "Statement by IMF Managing Director Christine Lagarde Following a Meeting with South Sudan's President Salva Kiir Mayardit" (www.imf.org/external/np/sec/pr/2011/ pr11472.htm); and PR No. 12/140, "Republic of South Sudan becomes IMF's 188th Member" (www.imf.org/exter $\mathrm{nal} / \mathrm{np} / \mathrm{sec} / \mathrm{pr} / 2012 / \mathrm{pr} 12140 . \mathrm{htm})$.

69 Diversity issues are addressed separately in the Diversity Annual Report, including a Discussion Note on Broadening the IMF Diversity Agenda, which is responsive to issues raised by the Executive Board in its May 2011 discussion on the 2010 Diversity Annual Report.

70 The IMF's Diversity Annual Reports are available at www .imf.org/external/np/div/index.asp.

71 See PIN No. 11/63, "IMF Executive Board Discusses the 2010 Diversity Annual Report" (www.imf.org/external/np/ sec/pn/2011/pn1163.htm).

72 See PR No. 11/187, "IMF Managing Director Dominique Strauss-Kahn Resigns” (www.imf.org/external/np/sec/pr/2011/ pr11187.htm).

73 See PR No. 11/191, "IMF Executive Board Initiates Selection Process for Next IMF Managing Director" (www.imf.org/ external/np/sec/pr/2011/pr11191.htm), and PR No. 11/195, "Statement by the IMF Executive Directors Representing Brazil, Russia, India, China and South Africa on the Selection Process for Appointing an IMF Managing Director" (www .imf.org/external/np/sec/pr/2011/pr11195.htm).

74 See PR No. 11/259, "IMF Executive Board Selects Christine Lagarde as Managing Director" (www.imf.org/external/np/ sec/pr/2011/pr11259.htm).

75 See PR No. 11/275, "IMF Managing Director Christine Lagarde Proposes Appointment of Mr. David Lipton as First Deputy Managing Director and Mr. Min Zhu as Deputy Managing Director" (www.imf.org/external/np/sec/pr/2011/ pr11275.htm).

76 For the full text of the IMF's transparency policy, see "The Fund's Transparency Policy” (www.imf.org/external/np/pp/ eng/2009/102809.pdf).

77 See "Key Trends in Implementation of the Fund's Transparency Policy" (www.imf.org/external/np/pp/eng/2011/070611.pdf).

78 www.ieo-imf.org.

79 See PIN No. 11/123, "IMF Executive Board Concludes Fourth Periodic Report on Implementing IEO Recommendations Endorsed by the Executive Board" (www.imf.org/ external/np/sec/pn/2011/pn11123.htm).

80 See "Ethics Framework: IMF Updates Standards for Staff Conduct" (www.imf.org/external/hrd/conduct.htm).

81 The Code of Conduct for Executive Directors is available at www.imf.org/external/hrd/edscode.htm.

82 The REOs are available via the REO web page on the IMF's website (www.imf.org/external/pubs/ft/reo/rerepts.aspx). Materials related to the REOs published in FY2012 can also be found on the website. 


\section{CREDITS}

This Annual Report was prepared by the Editorial and Publications Division of the IMF's External Relations Department. Tim Callen, Sandy Donaldson, and Nicole Laframboise oversaw the work of the Report team, which was under the direction of the Executive Board's Evaluation Committee, chaired by Moeketsi Majoro. The editors were Michael Harrup (who also served as chief writer and coordinated the drafting and production processes), S. Alexandra Russell, and Cathy Gagnet. Nicole Laframboise made substantial contributions to the writing. Teresa Evaristo and Phoebe Kieti provided editorial assistance.

Photography:

Stephen Jaffe/IMF staff photo

(c) imagebroker.net/SuperStock IMF staff photo

() Kenichiro Seki/Xinhua Press/Corbis

Pedro Ugarte/AFP Photo

PENG Zhaozh I/Xinhua/Landov

Paul Smith/Panos

ZHU Xiang/Xinhua/Landov front cover (top), pp. 4, 14 (right), 17 (top), 29 (left), 35 (bottom), 42 (left), 49 (top, bottom), 58 (left) front cover (bottom) pp. 5, 6, 7, 42 (right) p. 9 (top)

p. 9 (bottom) p. 10 (left) p. 10 (right) p. 13 (top) (c) Roderick Chen/SuperStock Jonathan Kirn/Stone/Getty Images Reuters/Jassim Mohammed (c) David Mdzinarishvili/Reuters/Corbis Reuters/Rafael Marchante Alimdi.net/Heiner Heine Christian Science Monitor/Getty Images Tom Martin/AWL-Images Tamal Roy/AP Photo

Reuters/Hazir Reka

Cosmos/eyevine

Sunday Alamba/AP photo (c) Ken Cedeno/Digital/Corbis Travel Pix Collection/AWL-Images Michael Spilotro/IMF staff photo Simon Reddy/Latitude Stock () Steve Vidler/SuperStock Robert Harding Productions/Newscom Alimdi.net/Heiner Heine Ubaldo Gonzalez/Xinhua/Landov Butsenko Anton/ITAR-TASS/Landov Ilya Naymushin/Reuters/Landov Xinhua/eyevine/Redux Giorgos Moutafis/EPA/Landov AFP Photo/Kazuhiro Nogi p. 13 (bottom)

p. 14 (left)

p. 17 (bottom)

p. 18 (left)

p. 18 (right)

p. 23 (left)

p. 23 (right)

p. 26 (left)

p. 26 (right)

p. 29 (right)

p. 32 (left)

p. 32 (right)

p. 33 (left)

p. 33 (right)

p. 35 (top)

p. 36 (left)

p. 36 (right)

p. 45 (left)

p. 45 (right)

p. 47 (left)

p. 47 (right)

p. 50 (left)

p. 50 (right)

p. 58 (right)

back cover

๑) INTERNATIONAL MONETARY FUND $2012 \quad$ DESIGN: DESIGN ARMY WWW.DESIGNARMY.COM

\section{CInternational Monetary Fund. Not for Redistribution}




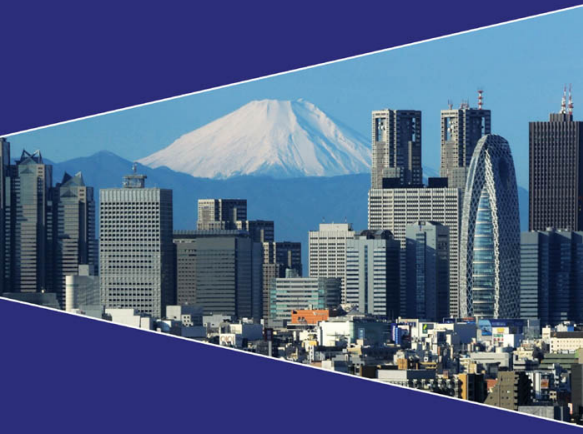

